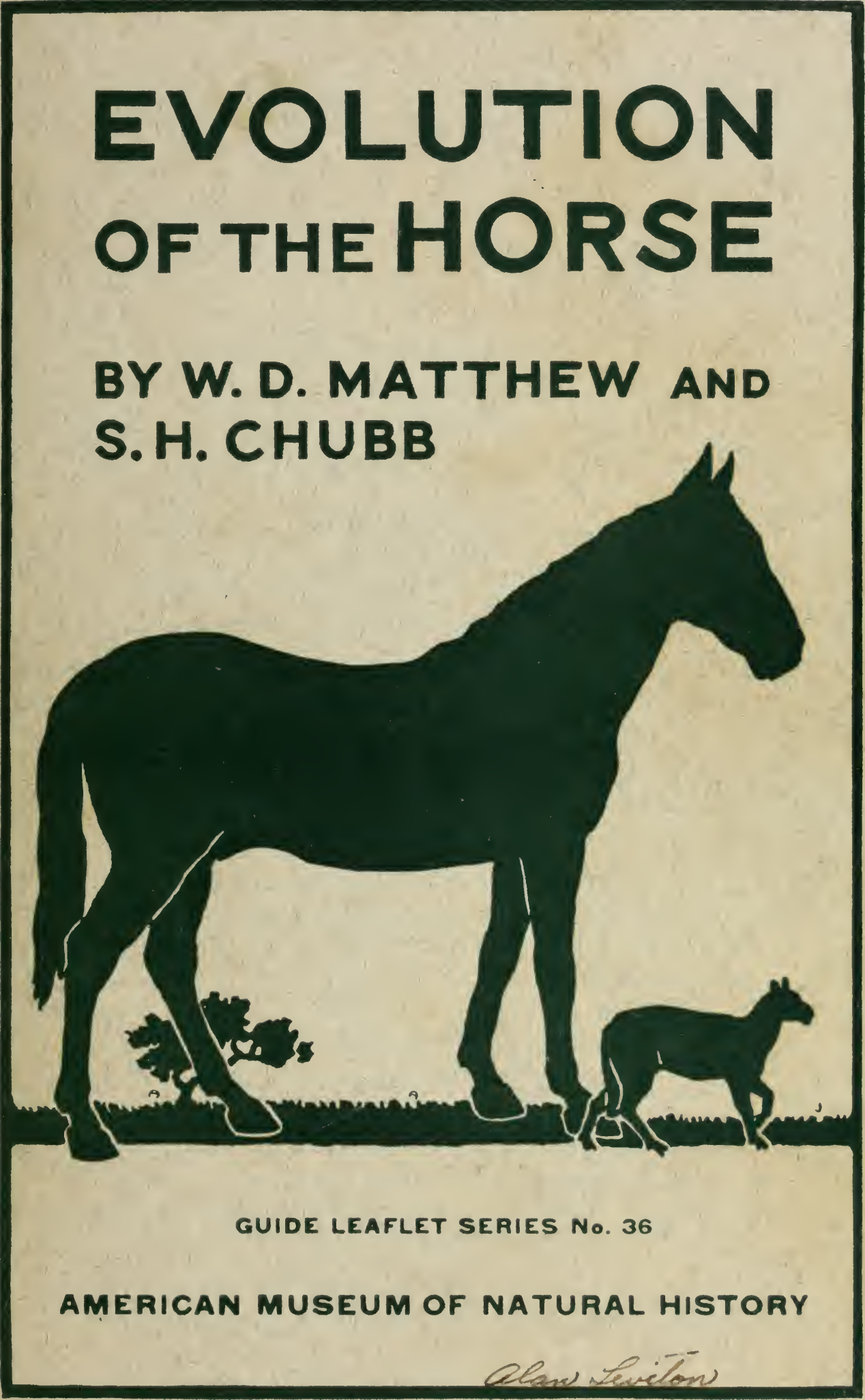


Issued under the direction of the Committee on Popular Publications

Roy W. Miner, Chairman 


\title{
EVOLUTION OF THE HORSE
}

\author{
IN TWO PARTS
}

EVOLUTION OF THE HORSE IN NATURE

BY

W. D. MAT'THEW

THE HORSE UNDER DOMESTICATION :

ITS ORIGIN AND THE STRUCTURE

AND GROWTH OF THE TEETH

BY

S. HARMSTED CHUBB

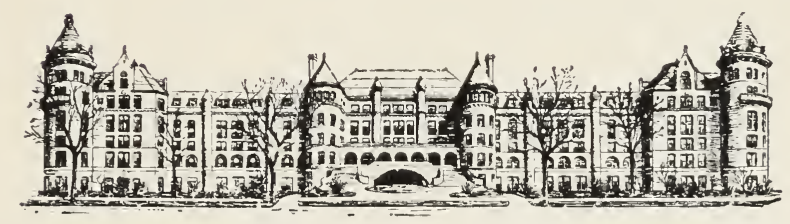

GUIDE LEAFLET SERIES

oF

THE AMERICAN MUSEUM OF NATURAL HISTORY

No. 36

SEVENTH EDITION 
“**** the general principles of the hypothesis of evolution lead to the conclusion that the horse must have been derived from some quadruped which possessed five complete digits on each foot; which had the bones of the forearm and of the leg emplete and separate; and which possessed forty-four teeth, among which the crowns of the incisors and grinders had a simple structure; while the latter gradually increased in size from before backwards, at any rate in the anterior part of the series, and had short erowns.

And if the horse has been thus evolved, and the remains of the different stages of its evolution have been preserved, they ought to present us with a series of forms in which the number of the digits becomes reduced; the bones of the forearm and leg gradually take on the equine condition; and the from and arrangement of the teeth successively approximate to those which obtain in existing horses.

Let us turn to the facts and see how far they fulfill these requirements of the doctrine of evolution."

Huxley. The Demonstrative Evidence of Evolution. 


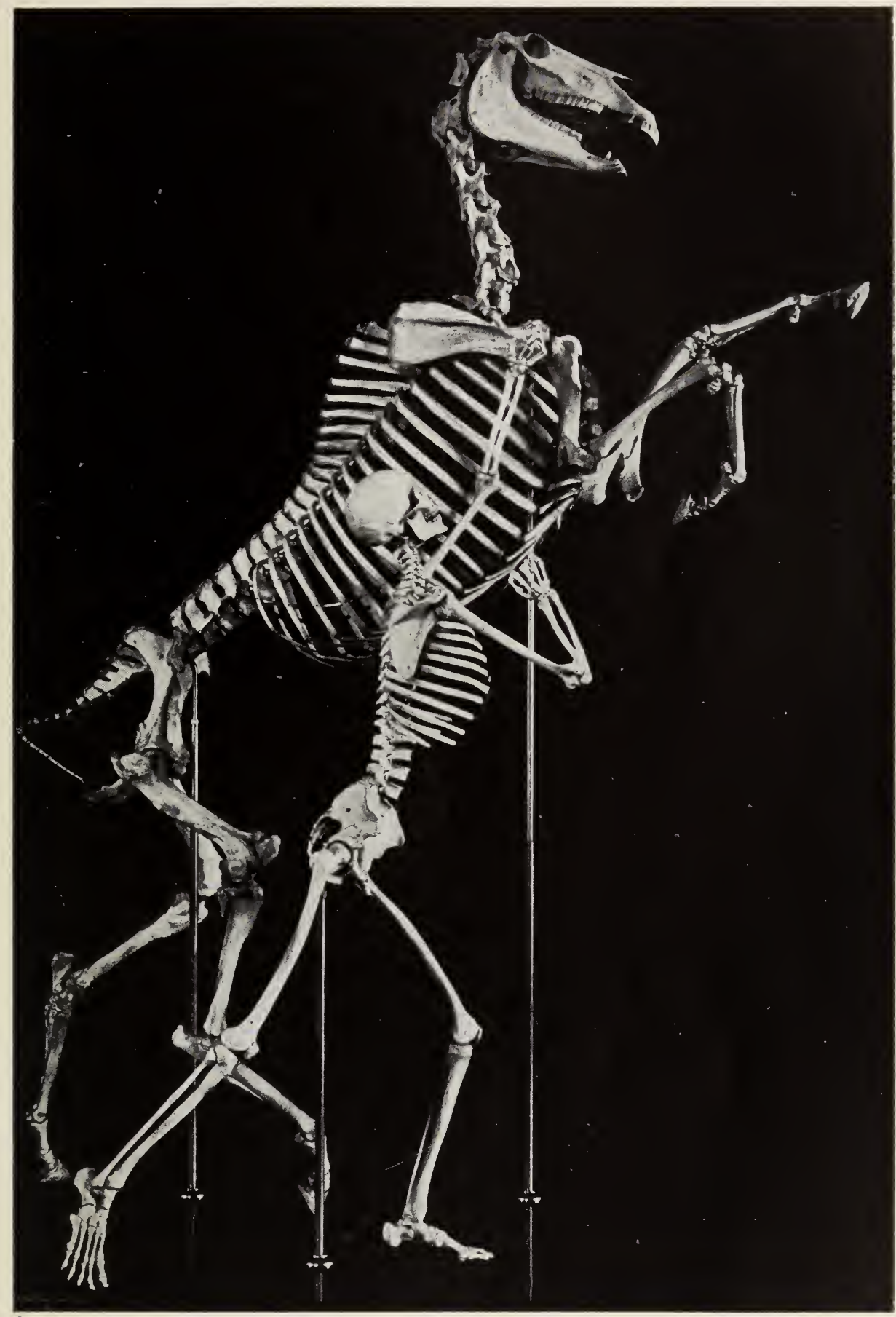

SKEIETON OF HORSE AND MAN

After Osborn

Mounted by S. H. Chubb for comparative study. Funds for the preparation, a gift of William C. Whitney to the American Museum of Natural History. 
Digitized by the Internet Archive in 2013 


\section{CONTENTS}

Part I. Evolution of the Horse in Nature

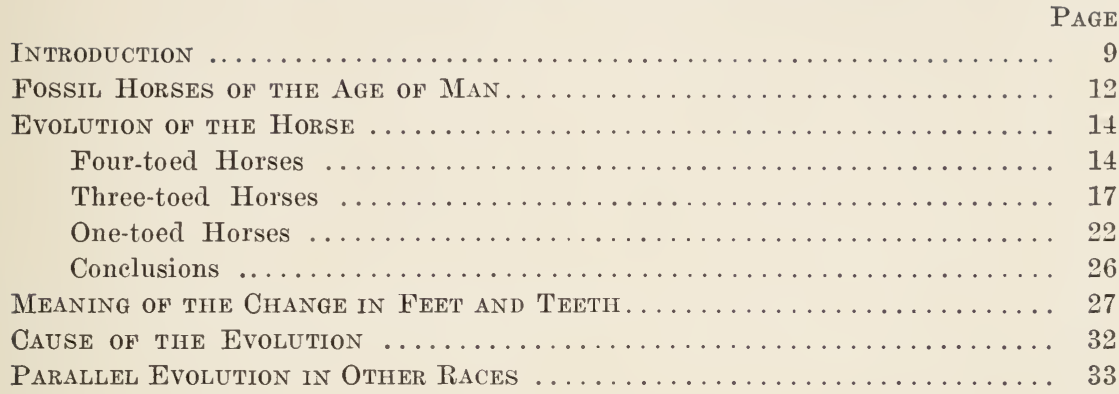

\section{Part II. The Horse under Domestication}

Origin of the Donestic Horse . . . . . . . . . . . . . . . . . . . . . 39

Comparison of the Skeletons of the Horse and of Man............ 41

The Draft Horse . . . . . . . . . . . . . . . . . . . . . . . . . . . . 41

Development of Great Size in the Draft Horse. . . . . . . . . . . . . . 43

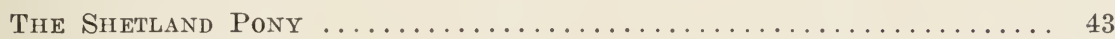

The Arabian Horse ................................... 44

The RACE Horse . . . . . . . . . . . . . . . . . . . . . . . . . . . . . 45

The Russian Wolfhound Compared with the Race Horse............ 48

The Trotting Horse ............................ 50

Wild Species of the Family Equidae ................... 52

The TeEth of the HoRse ............................ 53

Structure of the Teeth............................ 54

Wear and Compensating Movement of the Incisors............. 56

Designation of the Teeth.......................... 58

"Wolf" Tooth of the Horse......................... 59

Premolars and Molars of the Horse..................... 60

Eruption of the Teeth of the Horse.................... 66

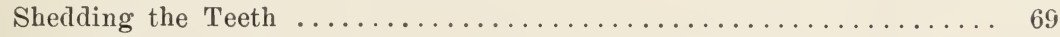

Equidae, Fossil and Modern, Principal Literature on the.......... 70

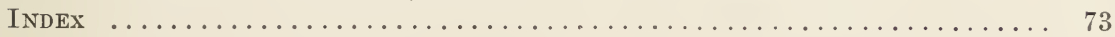




\section{LIST OF ILIUSTRATIONS}

PAGE

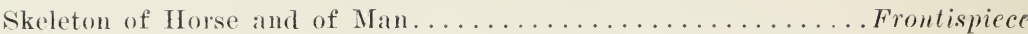

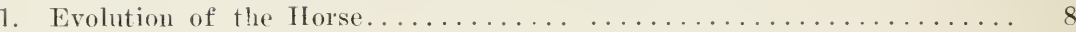

2. Evolution of the Fore Foot. Principal Stages................ 10

3. Evolution of the Hind Foot. Principal Stages................ 11

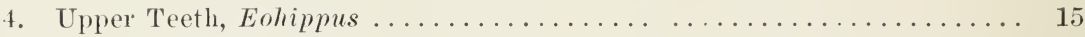

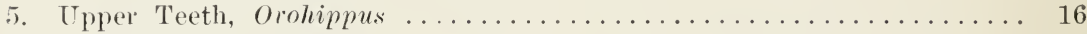

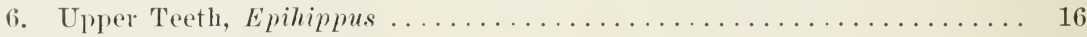

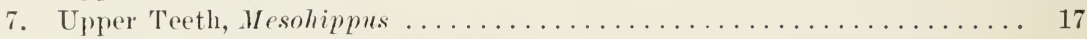

8. Little Three-toed Horse (Mesohippus bairdi) and Four-toed Horse (Eohippus venticolus) ....................... 18

9. Skeleton of Three-toed Desert Horse (Hipparion whitneyi) . . . . . ... 19

10. Upper Teeth, Parahippus ........................ 20

11. Upper Teeth, Merychippus _....................... 21

12. Upper Teeth, Hipparion $\ldots \ldots \ldots \ldots \ldots \ldots \ldots \ldots \ldots \ldots \ldots \ldots \ldots \ldots \ldots \ldots$

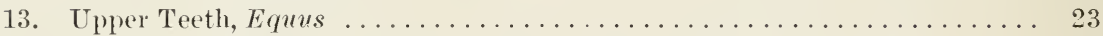

14. Skeleton of Extinct American Horse (Equus scotti) . . . . . . . . . 24

15. Skeleton of Short-limbed Horse, Hippidium............... 25

16. Geological and Geographical Range of Ancestors of Horse......... 26

17. Evolution of the Fore Leg. Principal Stages . . . . . . . . . . . 27

18. Evolution of the Hind Leg. Principal Stages................ 28

19, 20. Evolution of the Teeth........................ 29

21. Evolution of the Hind Foot of the Horse................. 31

2.. Fore and Hind Feet. Three-toed Psuedo-horse . . . . . . . . . . . . . 33

23. Fore and Hind Feet. One-toed Psuedo-horse. . . . . . . . . . . . . . . 34

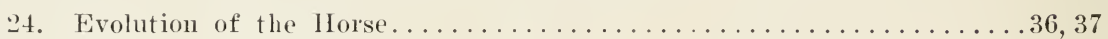

25. Giant Draft Horse and Shetland Pony.................. 38

26. Draft Hlorse P'ulling Heavy Load . . . . . . . . . . . . . . . . . . 40

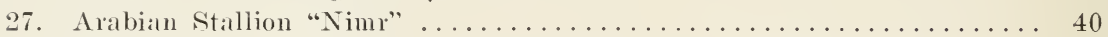

28. Draft Horse. Rear view showing action of pelvis and backbone...... 42

29. Famous American Race Horse "Sysonby" ................. 46

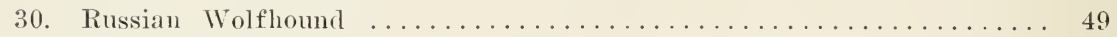

31. "Lee Axworthy," the World's Champion Trotting Stallion.......... 51

32. Incisor Teeth Showing Different Degrees of Specialization......... 55

33. Incisor Teeth Showing Wear and Movement............... 55

34. Designation of Teeth $\ldots \ldots \ldots \ldots \ldots \ldots \ldots \ldots \ldots \ldots \ldots \ldots \ldots \ldots \ldots$

35. Wearing Surface of Upper Grinding Teeth................ 61

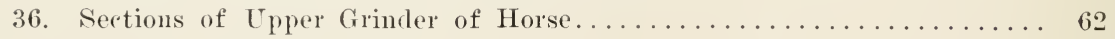

37. Lower Premolar of Horse $\ldots \ldots \ldots \ldots \ldots \ldots \ldots \ldots \ldots \ldots \ldots \ldots \ldots \ldots \ldots \ldots$

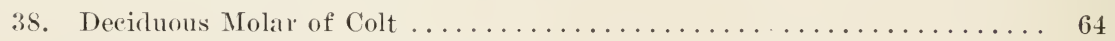

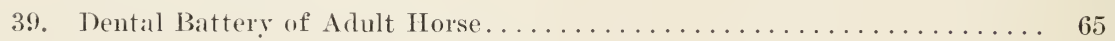

40. Dentition of the Colt $\ldots \ldots \ldots \ldots \ldots \ldots \ldots \ldots \ldots \ldots \ldots \ldots \ldots \ldots$ 


\section{PREFACE ${ }^{1}$}

Among all the animals of past and present there is none so deserving of our interest and affection as the horse. It is the most useful of the domestic animals, and has played the largest part in the development of eivilization. Since the dawn of recorded history the man with the horse las been in the forefront of progress. Whether leading the military civilizations of the past or breaking ground for the industrial civilization of the present the pioneers and leaders of progress have always made large use of this noble animal. It is not too much to say that without his help our ancestors in the old World might have advanced but little further on the road to eivilization than did the inhabitants of the ancient semi-civilized states of Peru and Mexico, where the horse was unknown, and travel, agriculture and military success were limited by the eapacity of unaided human strength.

From another point of view the horse is of peculiar interest. It is one of the most perfect machines for swift running that exists among living animals and displays throughout its organization the most exact and finished mechanism adapted to this purpose. It is perhaps the finest example of what nature, acting through millions of years, has been able to accomplish in the way of adapting a large quadruped to speed over long distances, and likewise of the extent to which man, during the few thousand years that he has controlled its development, has been able to improve upon nature, in the sense of adapting it to serve more exactly his own purpose.

The history of this adaptation, continued over millions of years, constitutes the evolution of the horse. Its records consist of the actual skeletons of the successive stages in the development of the race. Buried in ancient river deposits, petrified and preserved to our day in the successive geological strata, they have been discovered and disinterred through the diligent search of seientists during the last fifty years.

This Museum has taken especial interest in the evolution of the horse. The reeords of this history are most completely preserved in the western United States, and tinrough the liberality of the trustees of the American Museum, and in particular through special funds provided by the late William C. Whitney, by Professor Henry Fairfield Osborn and by other trustees and friends of the Museum, Messis. James R. Keene, Randolph Huntington, F. K. Sturgis and other's, we have obtained, from expeditions, gifts and purehases, many thousand specimens of fossil species, illustrating numerous successive stages in horse ancestry; and a unique series illustrating the diverse breeds of the domesticated animal and the structure and growth of its teeth and skeleton, so marvelously suited to its requirements.

Such parts of the collection as might best serve to illustrate the subject have been placed on exhibition in the hall of fossil mammals and in the West Corridor, on the Fourth Floor. These exhibits show

1. The Evolution of the Horse in Nature

2. The Evolution of the Horse under Donestication

The collections have been gathered together and arranged under the direction and supervision of Professor Henry Fairfield Osborn. Scientific descriptions of parts of the material have been published from time to time by Professor Osborn and his assistants and an extensive monograph on the evolution of the horse is now in preparation.

American Museum of Natural History, March, 1913

W. D. Matthew.

${ }^{1}$ Preface to First Edition 


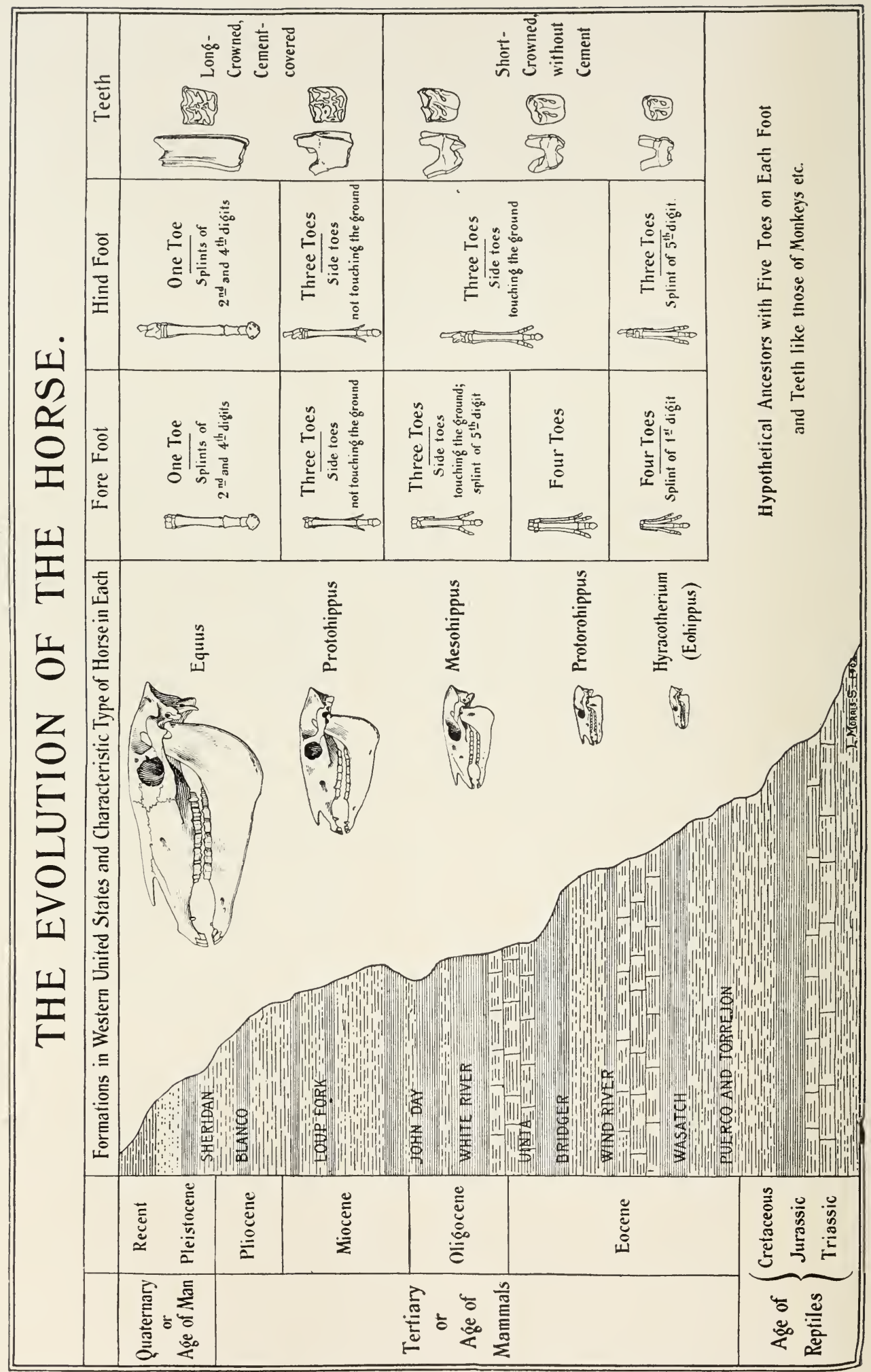




\title{
Part 1. EVOLUTION OF THE HORSE IN NATURE
}

\author{
By W. D. Matthew, Ph.D.
}

Late Curator of the Department of Vertebrate Palæontology

\section{INTRODUCTION}

S a domestic animal the horse is to be found almost everywhere
that man can live. He is spread all over the world-from torrid islands-he is completely cosmopolitan. But as a wild animal the horse is at present limited to the Old World, and is found there only in the open arid or desert plains of Central Asia and Africa. There are two species in Asia, the Asiatic wild ass (Equus hemionus) and the little known Przewalsky horse (Equus przewalskii), while in Africa there are the African wild ass (Equus asinus) and the several species of zebra (Equus zebra, Equus burchelli, Equus grevyi). In the Americas and Australia there are no true wild horses, the mustangs and broncos of the Western Plains and South America being feral (domesticated animals run wild) and descended from the horses brought over from Europe by the early white settlers. When the Spaniards first explored the New World they found no horses on either continent. The Indians were quite unfamiliar with them and at first regarded the strange animal which the newcomers rode, with wonder and terror, like that of the ancient Romans when Pyrrhus and his Greeks brought elephants-" the huge earth-shaking beasts" - to fight against them.

The horse is distinguished from all other animals now living by the fact that he has but one toe on each foot. Comparison with other animals shows that this toe is the third or middle digit of the foot. The hoof corresponds to the nail of a man or the claw of a dog or cat, and is broadened out to afford a firm, strong support on which the whole weight of the animal rests. Behind the "cannon bone" of the foot are two slender little bones, one on each side, called "splint bones." These represent the second and fourth digits of other animals, but they do not show on the surface and there is nothing like a separate toe. So that the horse may be said to be an animal that walks on its middle finger nail, all the other fingers having disappeared.

The teeth of the horse are almost equally peculiar. The molars are long, square prisms which grow up from the gums as fast as they wear off on the crowns. Their grinding surface exhibits a peculiar and complicated pattern of edges of hard enamel between which are softer spaces composed of dentine and of a material called "cement," much like the dentine in quality but formed in a different way. The dentine is formed 
on the inside surfaces of the enamel while the tooth is still within the jawbone; the cement is deposited on the outside surfaces of the enamel after the tooth has broken through the jawbone and before it appears above the gums.

Various other peculiarities dist ing $\mathrm{u}$ is h the horse from most other animals; some of these

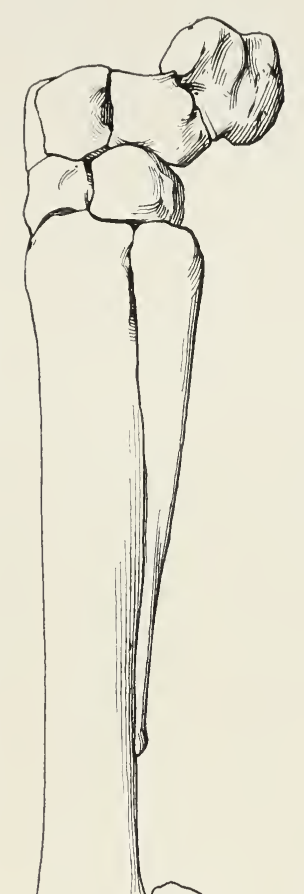

are shared by other hoofed animals. The two long bones of the forearm (radius and ulna) are separate in the greater number of animals, but in the horse and in many other hoofed animals, they are consolidated into a single bone (See Fig. 17, p. 27). The same consolidation is seen in the bones of the lower leg (tibia and fibula). (See Fig. 18, p. 28.) The lengthening of the foot and stepping on the end of the toe raises the heel in the horse, as in many otlier animals, to a con-

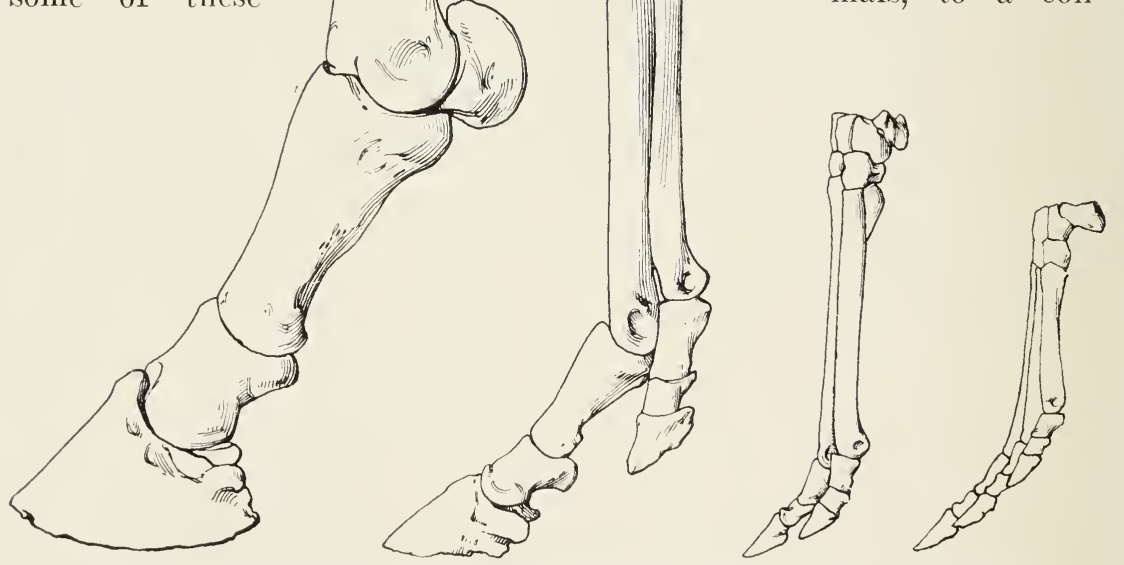

FIG. 2. EVOLUTION OF THE FORE FOOT. PRINCIPAI STAGES

(Right to Left)

1. Four-toed horse Eohippus. Eocene Epoch.

2. Early three-toed horse Mesohippus. Oligocene Epoch

3. Later three-toed horse Merychippus. Miocene Epoch

4. One-toed horse Equus. Pleistocene Epoch and Modern

All outside views showing the middle and outer digits of the fore foot. In Eohippus the two outer toes (digits IV and V) are complete. In Mesolippus, digit V is reduced to a small splint and digit IV is notably smaller than the middle digit. In Merychippus, digit $V$ is a tiny nodule of bone and digit IV has become very slender in comparison with the middle digit. In Equus digit IV is reduced to a long splint, while of the fifth digit no trace remains. 


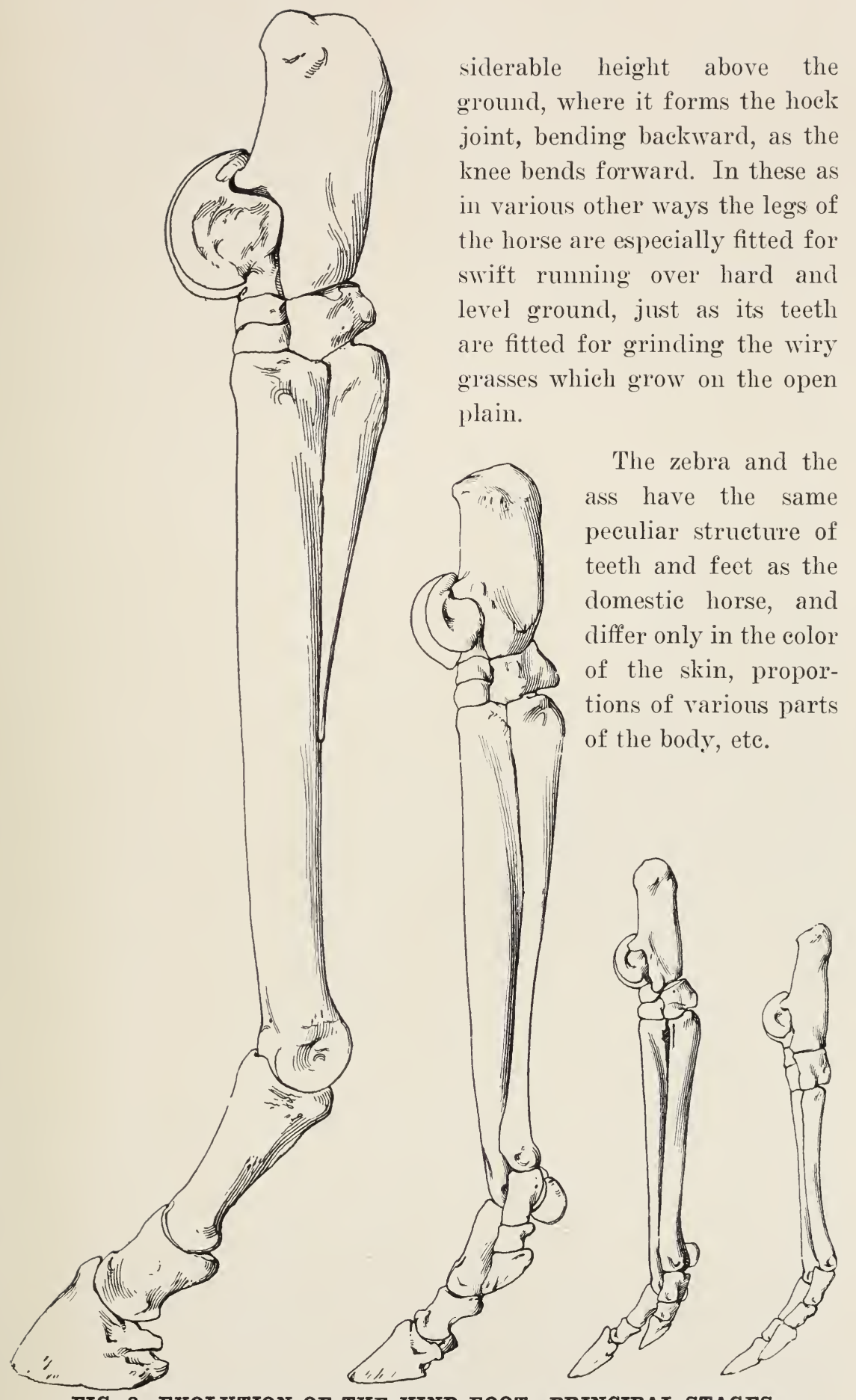

FIG. 3. EVOLUTION OF THE HIND FOOT. PRINCIPAI STAGES

(Right to Left) 1, Eohippus, Eocene Epoch; 2, Mesohippus, Oligocene; 3, Merychippus, Miocene; 4 , Equus, Pleistocene and Modern

Outer views showing middle and outer digits. Note progressive reduction of side toe (digit IV) from a well developed digit to a splint bone 


\section{FOSSIL HORSES OF THE AGE OF MAN}

$\mathrm{T}$ HE Age of Man, or Quaternary Period, is the last and by far the shortest of the great divisions of geological time. It includes the Great Ice Age or Glacial Epoch (Pleistocene), when heavy continental glaciers covered the northern parts of Europe and North America, and the Recent Epoch, of more moderate climate during which eivilization has arisen.

In the early part of the Quaternary Period, wild species of horse were to be found on every continent except Australia. Remains of these true native horses have been found buried in strata of this age in all parts of the United States, in Alaska, in Mexico, in Ecuador, Brazil and Argentina, as well as in Europe, Asia and Africa. All these horses were much like the living species and most of them are included in the genus Equus. Mr. J. W. Gidley, in charge of the American Museum expedition in northern Texas, discovered in 1899 a number of more or less complete skeletons of a species of fossil horse, Equus scotti, in an old river deposit on Rock Creek in Donley County. These are the most complete specimens known of the extinct horses which inhabited this country at the beginning of the Ice Age. A mounted skeleton and several skulls have been placed on exhibition, and their near resemblance to the modern animal appears at a glance. The difference from the domestic horse is chiefly in proportions: the skull is shorter with deeper jaws, the legs rather short and the feet small in proportion to the body. In these characters this fossil horse resembles an overgrown zebra rather than a domestic horse. We know nothing of its coloring. It may have been striped, and in this ease would have been very zebra-like; but there are some reasons for believing that it was not prominently striped. The bones are petrified, brittle and heavy, the animal matter of the bone having entirely disappeared and having been partly replaced by mineral matter. They are not much changed in color however, and are so perfectly preserved that they look almost like recent bone.

All the remains of these native horses which have been found in America have been petrified more or less completely. This means that they have been buried for many thousands of years, for true petrifaction is an exceedingly slow process. This condition serves as an easy means of distinguishing them from bones of the domestic horse, found buried in the earth. These cannot in any case have been buried for more than three or four centuries, and have not had time to petrify.

Remains of these fossil horses from various parts of the United States are shown in the counter cases. One very rich locality is on the Niobrara River in Nebraska, another is in central Oregon. Many separate teeth and bones have been found in the phosphate mines near 
Charleston, South Carolina; other specimens have come from central Florida, from southern Texas, Arizona, Kansas, Louisiana and even from Alaska. They are, in fact, so often found in deposits of rivers and lakes of the latest geological epoch (the Pleistocene) that the formation in the western United States has received the names of "Equus Beds."

In South America, in strata of the Pleistocene Epoch, there occurs, besides several extinct species of the genus Equus, the Hippidium, a peculiar kind of horse characterized by very short legs and feet, and some peculiarities about the muzzle and the grinding teeth. The legs were hardly as long as those of a cow, while the head was as large as that of a race horse or other small breed of the domestic horse.

All these horses became extinct, both in North and South America. Why, we do not know. It is very probable that man-the early tribes of prehistoric hunters - played a considerable part in their disappearance, not indeed by killing them all off directly, but by continual hunting and chasing, driving them from the best feeding-grounds and interfering with their habits and opportunities for grazing. This persecution would tend to reduce their numbers and vigor, and be the prelude to their extinction. The competition with the bison, which had recently migrated to $\Lambda$ merica, may also have made it more difficult than formerly for the American horse to get a living. And finally, some epidemic disease or prolonged season of drought may have exterminated the race. Whatever the cause, the horse had disappeared from the New World when the white man invaded it (unless a few individuals still lingered on the remote plains of South America), and in his place the bison had come and spread over the prairies of the North.

Fossil horses are equally common in the Pleistocene formations of the Old World. They have been found in all parts of Europe and Asia, in North and South Africa, but not in Australasia, the East Indies or Madagasear. In Central Asia, two wild races persist to the present day; others were domesticated by man in the earliest times, and their use in Chaldea and Egypt for draft and riding is depicted in the ancient mural paintings. In Africa the larger species became extinct in prehistoric times, as in America, but the smaller zebras still survive in the southern part of the continent (one species, the quagga, abundant fifty years ago, is now extinct), and the African wild ass is found in the fauna of the northern part. The wild horse of prehistoric Europe, a small race, shortlegged and shaggy-haired, was domesticated by man, ${ }^{1}$ a fact that is

${ }^{1}$ They are probably derived from three different wild sources which Professor Cossar Ewart has called the Forest Type of Northern Europe, the Steppe Type of Northern Asia, resembling the Przewalsky horse, and the Plateau or Desert Type of Northern Asia, resembling the Arabian.-Henry Fairfield Osborn. 
known from the rude drawings scratched on bone or ivory by men of the Neolithic or Polished Stone Age. But the domesticated horses now in use are derived chiefly from the Asiatic and African species although it is probable that in some breeds there is a considerable strain of this shaggy, short-legged European race. The domesticated ass is a descendant of the wild ass (Equus asinus) of North Africa.

\section{THE EVOLUTION OF THE HORSE}

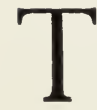

HE history of the evolution of the horse through the Tertiary Period of Age of Mammals affords the best known illustration of the doctrine of evolution by means of natural selection and the adaptation of a race of animals to its environment. The ancestry of this family has been traced back to near the beginning of the Tertiary without a single important break. During this long period of time, estimated at nearly three millions of years, these animals passed through important changes in all parts of the body, but especially in the teeth and feet, adapting them more and more perfectly to their particular environment, namely the open plains of a great plateau region with their scanty stunted herbage, which is the natural habitat of the horse.

In the series of ancestors of the horse we can trace every step in the evolution of those marked peculiarities of teeth and feet which distinguish the modern animal from an ancestor which so little suggests a horse that when its remains were first found forty years ago, it was named by the great palæontologist Richard Owen, the Hyracotherium or "coney-like beast." Its relation to the horse was not at that time suspected by Professor Owen, and was recognized by scientific men only when several of the intermediate stages between it and its modern descendant had been discovered. On the other hand this first ancestor of the horse line is very difficult to distinguish from the contemporary ancestors of tapirs and rhinoceroses, and indicates how all the modern quadrupeds have diverged from a single type, each becoming adapted to the needs of its especial mode of life.

\section{FOUR-TOED HORSES}

$\mathrm{T}$

HE earliest known ancestors of the horse were small animals not larger than the domestic cat, with four complete toes on each fore foot and three on each hind foot. There is reason to believe that still more ancient ancestors of this and all other mammals had five toes on each foot. In the fore foot of the earliest known stage there may have been a small, slender rudiment representing the missing first digit or thumb, which no longer appeared on the surface of the foot, ${ }^{1}$ while in the

${ }^{1}$ It is shown in Marsh's well known diagram; but there is no conclusive evidence of its presence on any specimen yet found. 
hind foot there is a similar rudiment representing the outer or fifth digit, and also a tiny remnant of the innermost or first digit. The proportions of the skull, the short neck and arched back and the limbs of moderate length, were very little horselike-recalling on the contrary, some modern carnivorous animals, especially the civets (Viverrida). The teeth were short-crowned and covered with low rounded knobs of enamel, suggesting those of monkeys and of pigs or other omnivorous animals, but not at all like the long-crowned complicated grinders of the horse.

Commencing with the Hyracotherium, twelve stages have been recognized from as many successive formations, showing the gradual evolution of the race into its modern form, and each stage is characteristic of its particular geological horizon. Some of the stages have been found in several parts of the world, but by far the most complete and best known series comes from the Tertiary Badlands of the western United States. Besides the main line of descent which led into the modern horses, asses and zebras, there were several collateral branches which have left no descendants. Of some stages all parts of the skeleton have been found; of others only the jaws, or jaws and feet, are known. We can mention only the more important stages.

1 and $2^{1}$. Hyracotherium and Eohippus Lower Eocene. The Hyracotherium is the most primitive stage known, but only the skull has been found, so that it has not been determined exactly what the feet were like. The teeth display six rounded knobs or cusps on the upper molars and four on the lower ones, and these are just beginning to show signs of fusing into cross-crests. The premolar teeth have only one main cusp, except the third and fourth premolars (next the molars) in each jaw, which have two and three, respectively. The only specimens which have been found were in the London Clay or Lower Eocene of England and are preserved in the British Museum.

The Eohippus is much better known. It comes from the Lower

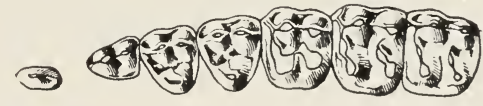

Fig. 4. Eohippus. Lower Eocene. Upper teeth, natural size. Shorterowned teeth, no cement, premolars simpler and smaller than molars

Eocene of Wyoming and New Mexico, and is very like the Hyracotherium ${ }^{2}$ except that in some species the molar teeth have the cusps more clearly fusing into cross-crests; the last premolar is beginning to look like one of the true molars. The fore foot of this animal lias four complete toes. The hind foot has three complete toes and the splints of the first and fifth digits can still be detected in some species. A skeleton of

${ }^{1}$ These numbers refer to the stages in the direct line of descent of the modern horse.

${ }^{2}$ It is doubtful whether it is a distinct genus. 
Eohippus was found by Dr. J. I. Wortman in 1880 in the Wind River Badlands of Wyoming, and was described by Professor Cope in 1885. It was until recently the only skeleton known of a four-toed horse, and is well known to the scientific world. It was purchased by the trustees of the American Museum in 1894 and is now on exhibition.

A second skeleton found by the Museum expedition of 1910, is of a larger species, but not advanced in any other respect. It is mounted in a grazing attitude, and probably represents the general appearance of Eohippus more truly than the Cope skeleton. A third imperfect skeleton secured in 1911 is interesting as it shows the tiny splint bone of the inner digit of the hind foot, indicated by facets in other specimens but not actually found before. Crushed skulls, jaws and fragments of skeleton bones of thousands of individuals have been found in the Lower Eocene formations.

3. Orohippus. Midde Eocene. In this animal the splints of the first and fifth digits of the hind foot have disappeared, but there are still four complete and usable toes in the fore and three in the hind foot. The crests on the molars are a little clearer and the last premolar has become almost like the molars, while the next to the last premolar is partially molariform. A skeleton of Orohippus, discovered by Mr. Walter Granger of the Museum expedition of 1906, in the Bridger Badlands of southwestern Wyoming, is exhibited next to the Eohippus skeleton. It shows an animal of the size of a small dog and proportioned much like the breed known as the whippet.

'The Orohippus was of about the same size and proportions as some of the pigmy antelopes or duiker-

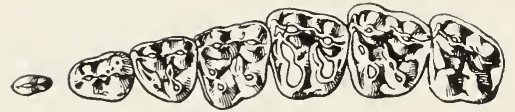

Fig. 5. Orohippus. Middle Eocene. Upper teeth, natural size. Shortcrowned teeth, no cement, fourth premolar like molars

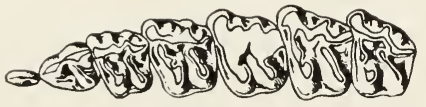

Fig. 6. Epihippus. Upper Eocene. Upper teeth, natural size. Shortcrowned teeth, no cement, third and fourth premolars like molars pletely converted into crescents and crests, while another tooth of the premolar series has become like the molars. The toes are still four in 
the fore foot and three in the hind foot, but the central toe in each foot is becoming much larger than the side toes.

Palcotherium and Plagiolophus of the Upper Eocene of Europe form a side branch of the horse line. They were very abundant in Europe, but have not been found in the New World. One of these animals was thought by Professor Huxley to be a direct ancestor of the horse, but it is now considered to be merely a collateral relative. Some species of Palcotherium were of large size, equal to a tapir. They were first described in the year 1804 by the celebrated Baron Cuvier from remains found in the gypsum quarries of Montmartre, Paris.

\section{THREE-TOED HORSES}

5, 6, and 7. Mesohippus and Miohippus. Oligocene. In this stage there are three toes on each foot, and a splint representing the fifth digit of the fore foot of the Eocene ancestors. The middle toe is now much larger than the side toes, which bear very little of the weight of the animal. Three of the premolars have now become entirely like the molar teeth, the crests on the crown are completely formed, and the outside crest in the upper molars has taken the shape of two crescents. In the Lower and Middle Oligocene are found several species of Mesohippus mostly of the size of the coyote, represented by two mounted skeletons, and various skulls, jaws and feet. In the Upper Oligocene occurs Miohippus intermedius as large as a sheep, of which a fine skeleton is exhibited in the pavilion case. Several other species of larger or smaller size are represented by skulls and jaws.

The series of skeletons in the pavilion case shows in a very striking way the steady increase in size from the Lower Eocene to the Upper Oligocene, and the reduction of the side toes with concentration of the weight upon the middle toe.

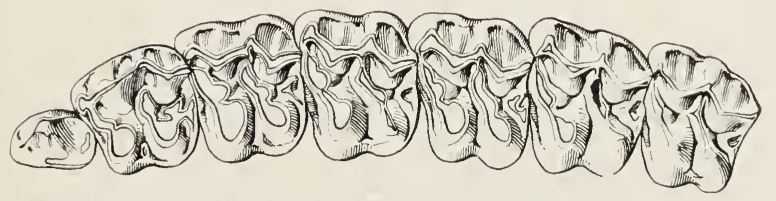

Fig. 7. Mesohippus. Middle Oligocene. Upper teeth, natural size. Shorterowned teeth, no cement, second, third and fourth premolars like molars.

8a. Anchitherium and Hypohippus. MIOcEne. Anchitherium has been found only in Europe, and is still very incompletely known. It is much like Mesohippus, but is larger and has the crests of the teeth somewhat higher and more complete. Hypohippus is off the direct line of descent; its teeth are like those of Anchitherium, by which name it 

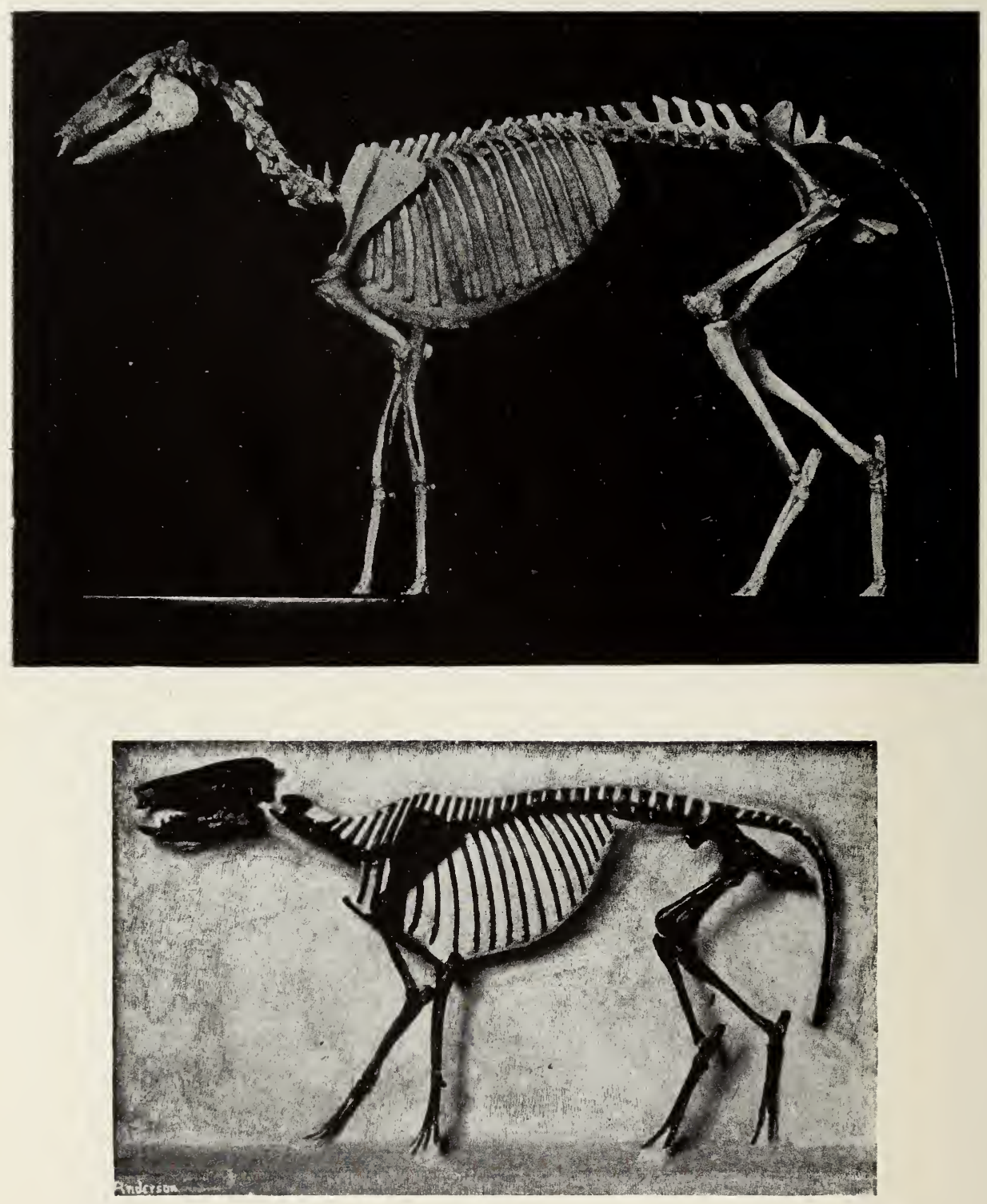

Fig. 8. Little three-toed horse (Mesohippus bairdi) from the Middle Oligocene of South Dakota. American Museum No. 1492

Four-toed horse (Eohippus venticolus) from the Lower Eocene of Wyoming, American MIuseum No. 4832 


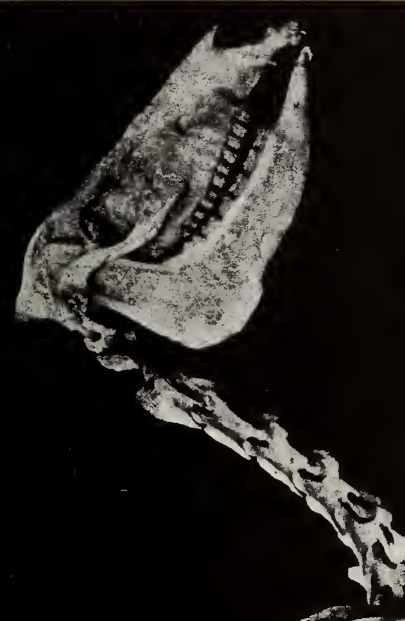

$\frac{1}{2}$
0
0
0
0
0
0

$\widehat{\frac{3}{\infty}}$

$\stackrel{3}{\circ}$

1
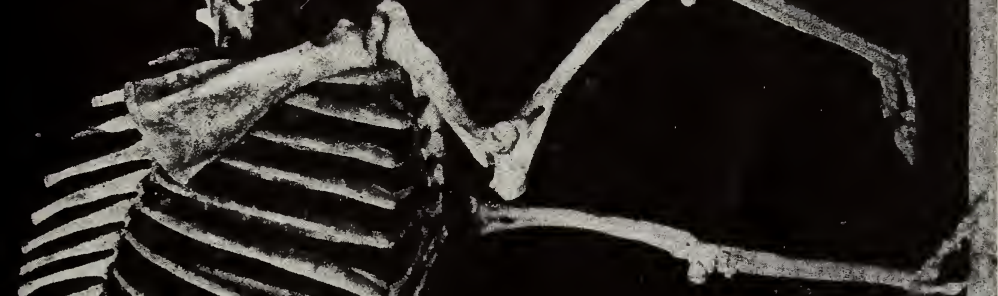

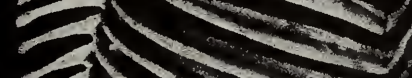

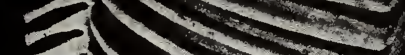

21120

$\longrightarrow x$

$\rightarrow 1$

Lil

$\infty 1$

$\operatorname{mos}$

ril nos

$\lim _{1}$

$\rightarrow$
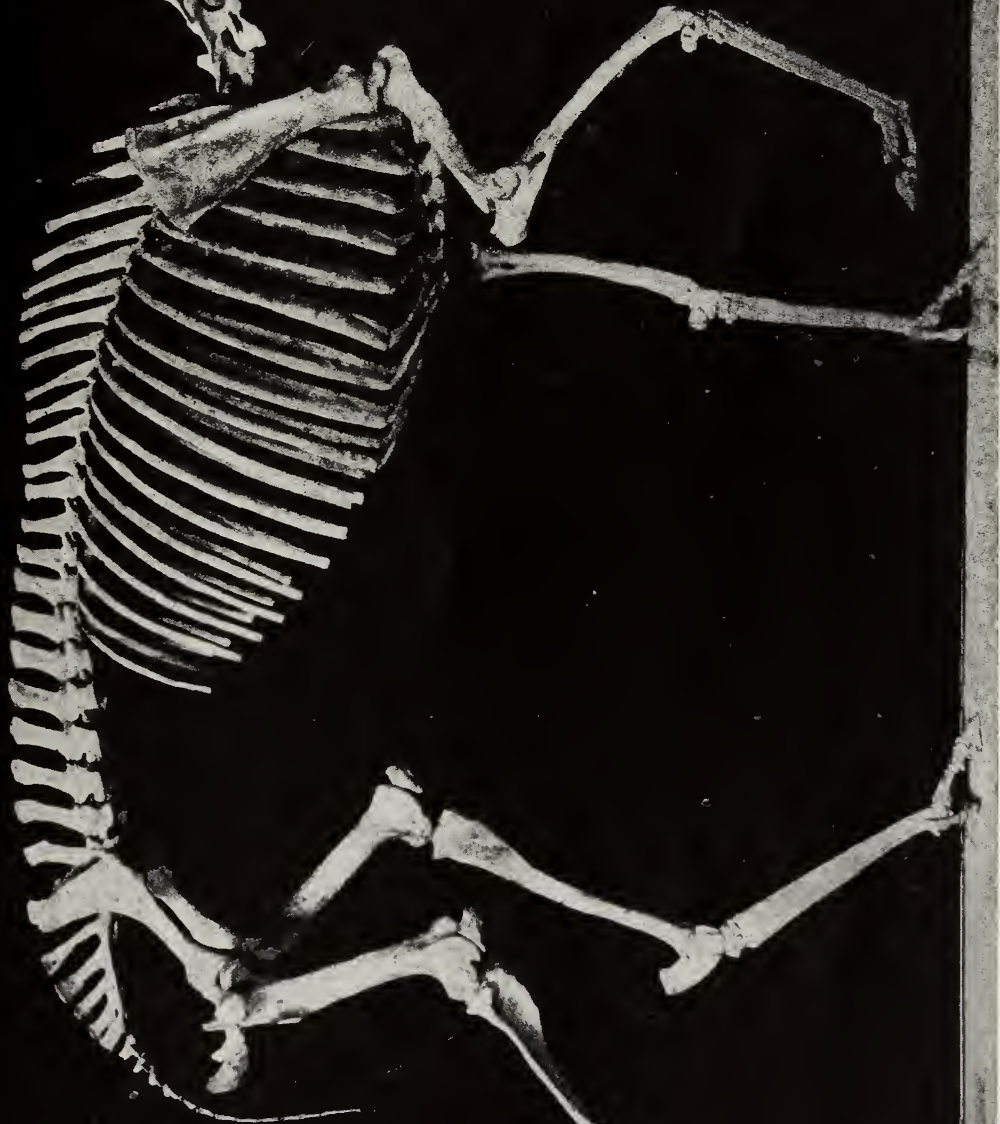

₹

క

๕ั

$\approx$

$\approx$

内.

要

운

ค I

숭

플

$A$ 인

ผ

อ

น

H

का 0

-

द

0.

幽艺

ผ

ผ

究

ค

क

⿷匚

도 
has been generally called, but the animal was much larger, equalling a Shetland pony in size. A complete skeleton of the Hypohippus (shown in wall case) was found near Pawnee Buttes, Colorado, in 1901 by Mr. Barnum Brown, of the Whitney expedition.

Hypohippus first appears in the Middle Miocene, and survives along with more advanced stages of the three-toed horses. It is a larger and more heavily proportioned animal; the wide flat hoofs and strong side toes enabled it to tread on soft ground, and the teeth are fitted for browsing rather than grazing. Hence Professor Osborn considers it as adapted for a forest life, and has named it the "three-toed forest horse." The restoration illustrates this supposed habitat and adaptation.

8 and 9. Parahippus. Mrocene. In Parahippus the tooth-crests are somewhat higher, and the transverse ridges on the upper molars are beginning to change shape so as to become a second pair of crescents inside the outer pair. In the valleys between the cross-crests and on the sides and base of the crown, a deposit of cement appears on the surface of the enamel. In some species there is a considerable amount, but usually it is a very thin coat. There is no cement on the milk teeth. The feet show a decided advance over the preceding stages, the side toes are very slender, and no longer touch the ground. The fifth digit of the fore foot is in some species a very short small splint, in others it is still further reduced to a little irregular nodule of bone. This stage first appears in the Lower Miocene, and several skulls and incomplete skeletons have recently been obtained from formations of this age. It survived however, although rare, as a contemporary of the later three-toed

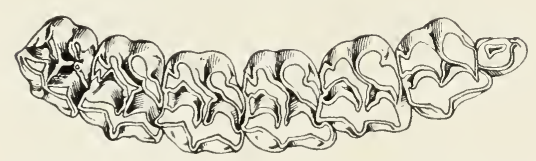

Fig. 10. Parahippus. Lower Miocene. Upper teeth, one-half natural size. Shortcrowned teeth, traces of cement. The teeth are larger than in Mesohippus [the drawing is on a smaller scale], the crowns a little longer, and the inner "crests" begin to show the change to "crescents" no cement; they are not easily distinguishable from those of Parahippus. The side toes are slender and no longer reach the ground; in some species they are almost reduced to splints. Merychippus is common in the Middle and later Miocene, and many skulls, jaws and incomplete skeletons are contained in our collections, some of which are placed on 
exhibition. These very perfect specimens show a vestige of the fifth digit in the fore foot still preserved as a tiny nodule of bone at the back of the wrist.

11. Hipparion, Protohippus and Pliohippus. UpPer MioCene and Pliocene. These three closely related genera represent the latest stage of three-toed horses, before the side toes were reduced to splints. The teeth are long-crowned, both milk and permanent teeth being heavily cemented, and the side toes are extremely slender. They first appear in the Upper Miocene, probably directly descended from Middle Miocene species of Merychippus, and are best represented by the beautifully preserved skeleton of Hipparion whitneyi from Little White

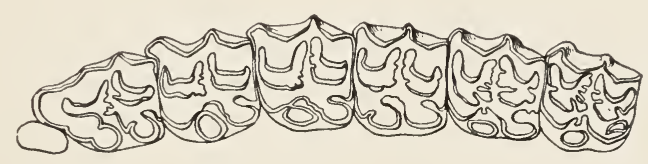

Fig. 11. Merychippus. Middle Miocene. Upper teeth, one-half natural size. Moderately long-crowned teeth, well cemented

River, South Dakota, found by Mr. H. F. Wells of the Whitney expedition of 1902. This species, except for the very large head, had the graceful and slender proportions of the antelopes but in Protohippus and especially in Pliohippus the skeleton approached more nearly the stockier proportions of the modern horses. The Hipparion whitneyi is regarded by Professor Osborn as fitted to live in a semi-desert country, and in contrast to the Hypohippus, is called the "three-toed desert horse." The restoration depicts this adaptation and environment.

In this stage the crowns of the upper molars have become much longer, the two pairs of crescents on the upper molars are complete, with two half-separated cusps within the inner pair. And the valleys between the crests are completely filled with cement, so that with the wear of the teeth the edges of hard enamel are backed inside by dentine and outside by cement. In this way the surface of the tooth has a series of enamel ridges always projecting a little above the grinding surface, because the softer material on each side wears down into hollows, yet never breaking off, because they are braced so thoroughly on each side. This is a very efficient instrument for grinding hard grasses. The crowns of the teeth in these Miocene horses are by no means as long as in the modern horses ; they must therefore have worn more slowly or worn out at an earlier age.

The feet in these genera have but one toe touching the ground. The side toes (second and fourth digits) are complete, but much more slen- 
der than in the earlier stages and are apparently useless, as they cannot reach the ground. In some speeies they have almost disappeared. The fore feet of these Upper Miocene horses still retain the tiny nodule of bone at the back of the "knee" (the joint that corresponds to the wrist of a man), which is the last remnant of the fifth digit possessed by their remote ancestors.

Hipparion is common in Europe and Asia as well as in North America, but Protohippus and Pliohippus are not found in the Old World.

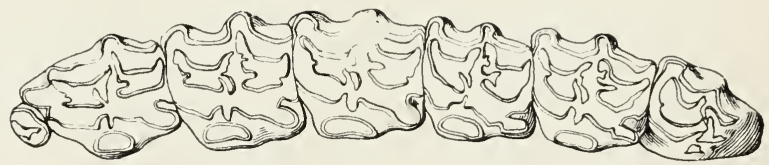

Fig. 12. Hipparion. Lower Pliocene. Upper teeth one-half natural size. Long-crowned teeth, heavily cemented.

\section{ONE-TOED HORSES}

12. Pliohippus. Pliocene. In some species of Pliohippus, although not in all, the side toes are still further reduced to long slender splint-like bones which are enclosed within the skin, the little separate toes having disappeared. These are the first of the One-toed Horses. The splint is nearly as long as the camnon bone, much longer than it is in Equus. Two fine skeletons of Pliohippus in the Museum collections (P. leidyanus, adult, and P. lulliamus, roung) admirably illustrate this stage. ${ }^{1}$ They are of somewhat later geologic age than the Hipparion skeleton, and nearer to the modern horse in size, proportions and various details of structure. Yet they are so much like other species of Pliohippus in which the side toes are still complete that both are placed in the same genus. Pliohippus is therefore transitional from the threetoed to the one-toed stage. It may be that some of the later species of IIipparion were also one-toed, but at present there is no proof of it.

13. Plesippus. Plocene. This stage, recently distinguished, is the long missing transition between Pliohippus and Equus. The side toes are even more reduced than in Pliohippus. They were splints buried beneath the skin, but are still a little longer than in Equus. The fifth

${ }^{1}$ Pliohippus was described in 1874 by Professor Marsh, as a one-toed ancestor of the horse; but his specimens do not prove that the side toes were certainly absent. These two skeletons found in 1917 by H. J. Cook and 1916 by E. R. Troxell show this conclusively, and we are therefore able to distinguish them as a separate stage in the evolution of the horse. In previous editions of this guide, 1903, 1905, 1913, this stage was not distinguished, as conclusive proof from specimens had not been found. 
digit and the trapezium are still present as tiny nodules of bone, but smaller than in Pliohippus. Similar characters intermediate between the first one-toed horses and the modern horse occur throughout the skeleton. The tooth pattern is nearly as in Pliohippus, but approaches Equus in having longer and less curved crowns. This stage is represented in our collection by a fine skeleton of Plesippus simplicidens found in the Panhandle of Texas in 1924 by Matthew and Simpson. ${ }^{1}$

14a. Equus. Pleistocene and Recent. In this stage, that of the modern horse, the side toes have entirely disappeared and are represented by moderately long splints on the fore and hind foot. No trace remains on the fore foot of the little nodule which in previous stages

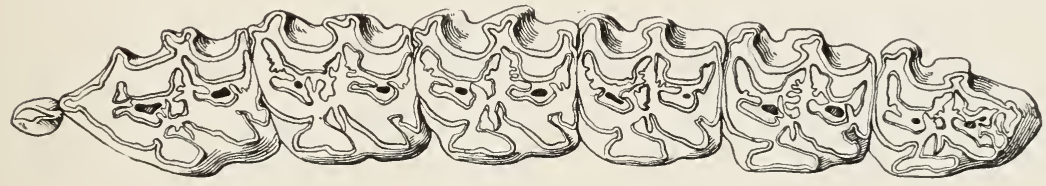

Fig. 13. Equus. Pleistocene. Upper teeth, one-half natural size. Very longcrowned teeth, heavily cemented

represented the fifth digit, while on the inner side of the wrist the "trapezium," ahways present in the earlier stages, but progressively smaller, is now generally absent entirely. The crowns of the teeth are much longer, and of the two half-separated inner columns on the upper molars, one has disappeared, the other has increased in size and changed in form. The skull has lengthened and the animal is much larger.

It is well represented among the fossil horses by the skeleton and skulls of Equus scotti already noticed and by skulls, jaws and teeth of other species from various localities.

14b. Hippidium, Onohippidium. Pleistocene. South AmerIC.. The feet are like those of Equus, except that they are short and stout. The teeth are like those of Pliohippus, from which it is supposed to be descended. The skull is large and long with very long slender nasal bones. A cast of the skeleton of Hippidium presented by the Museo Nacional of Buenos Ayres, Argentine Republic, is on exhibition, also a skull cast of Onohippidium.

${ }^{1}$ This species was previously known from isolated teeth and this find first proved that it represents a separate generic and evolutionary stage and that Equ is derived through this stage from Pliohippus rather than from Hipparion. In 1929-31, under the direction of the late Dr. J. W. Gidley, the United States National Museum discovered a wonderful series of skulls and skeletons of this genus ( $P$. shoshonensis) on the old Oregon trail in Idaho. 


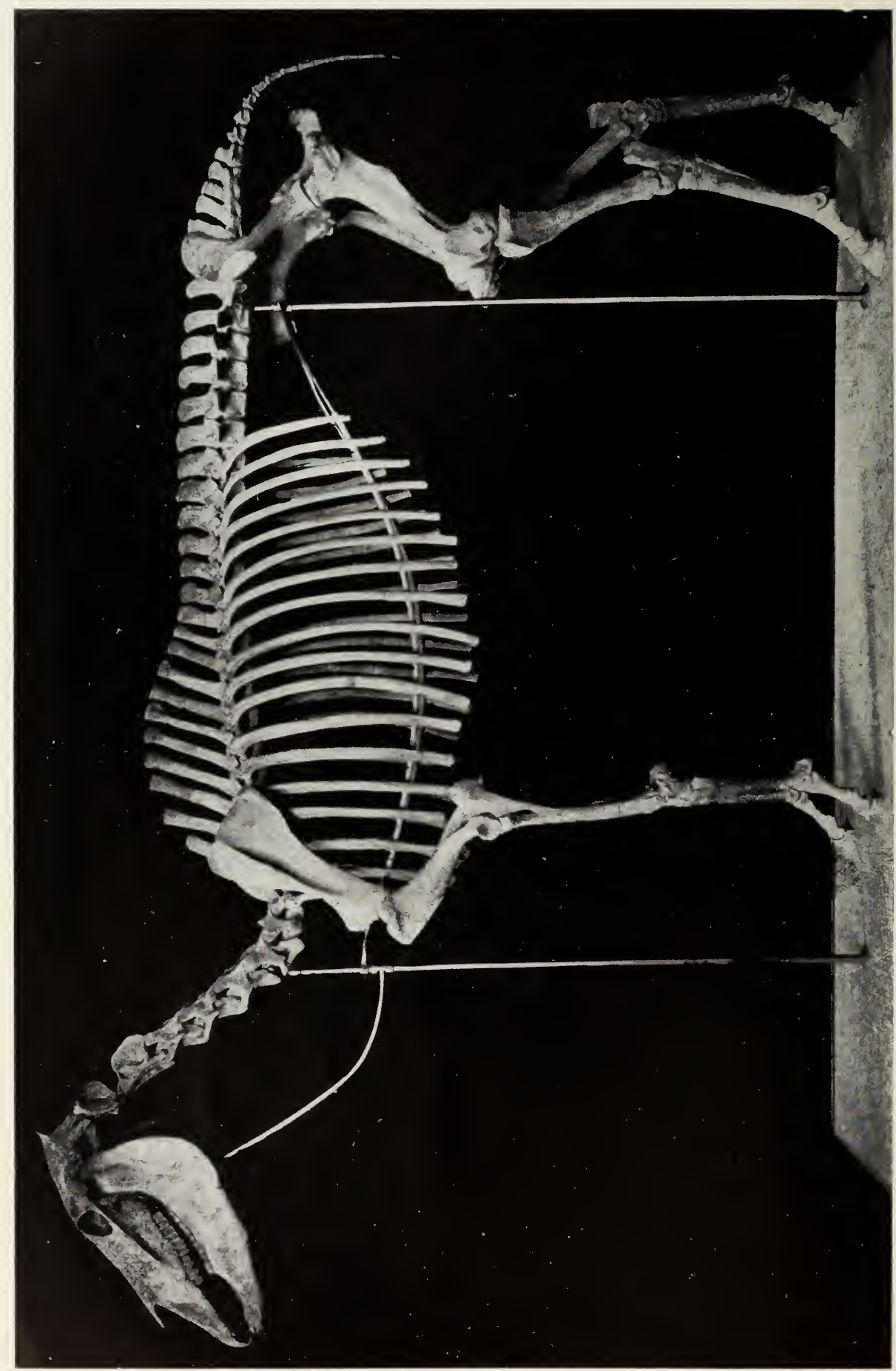




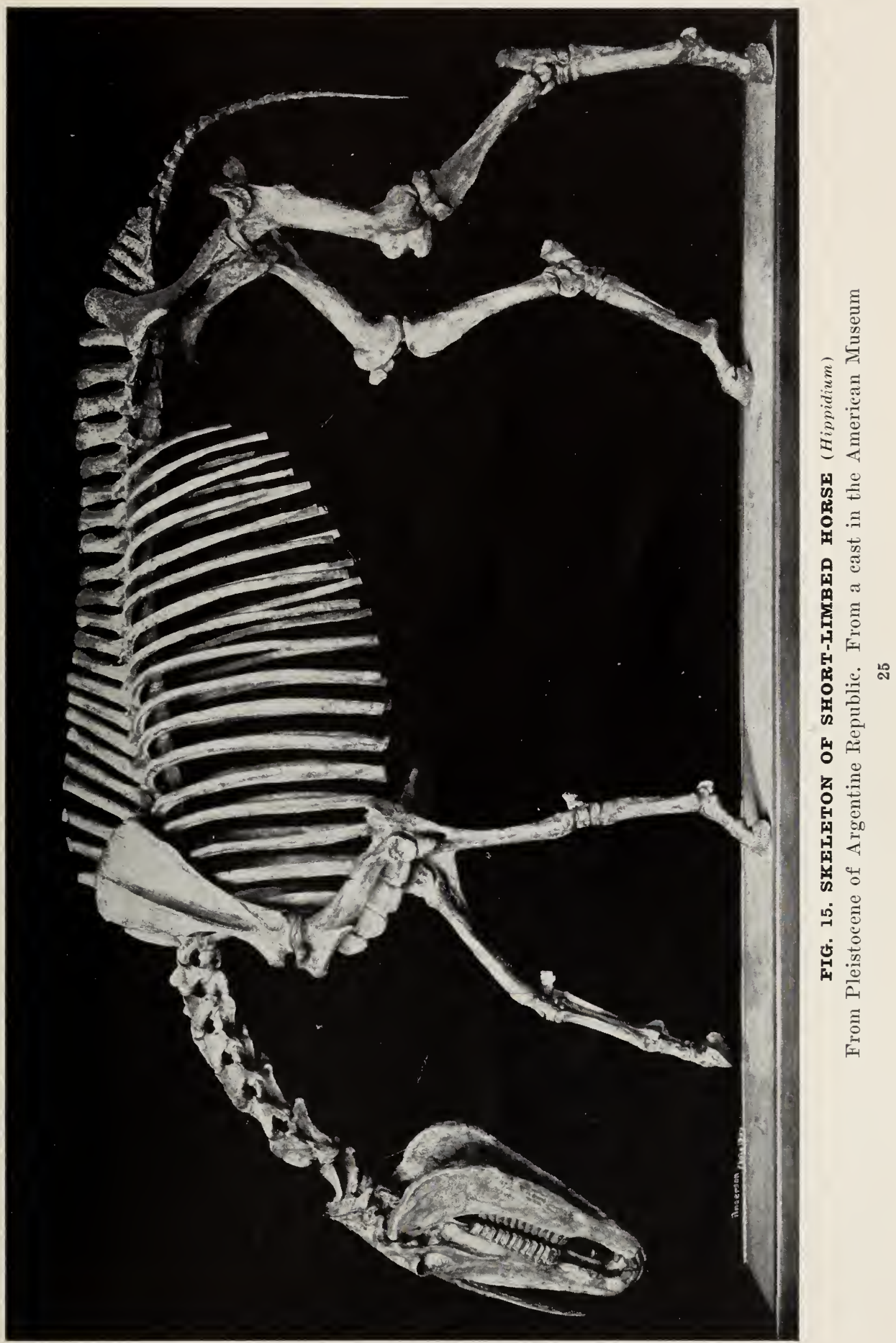




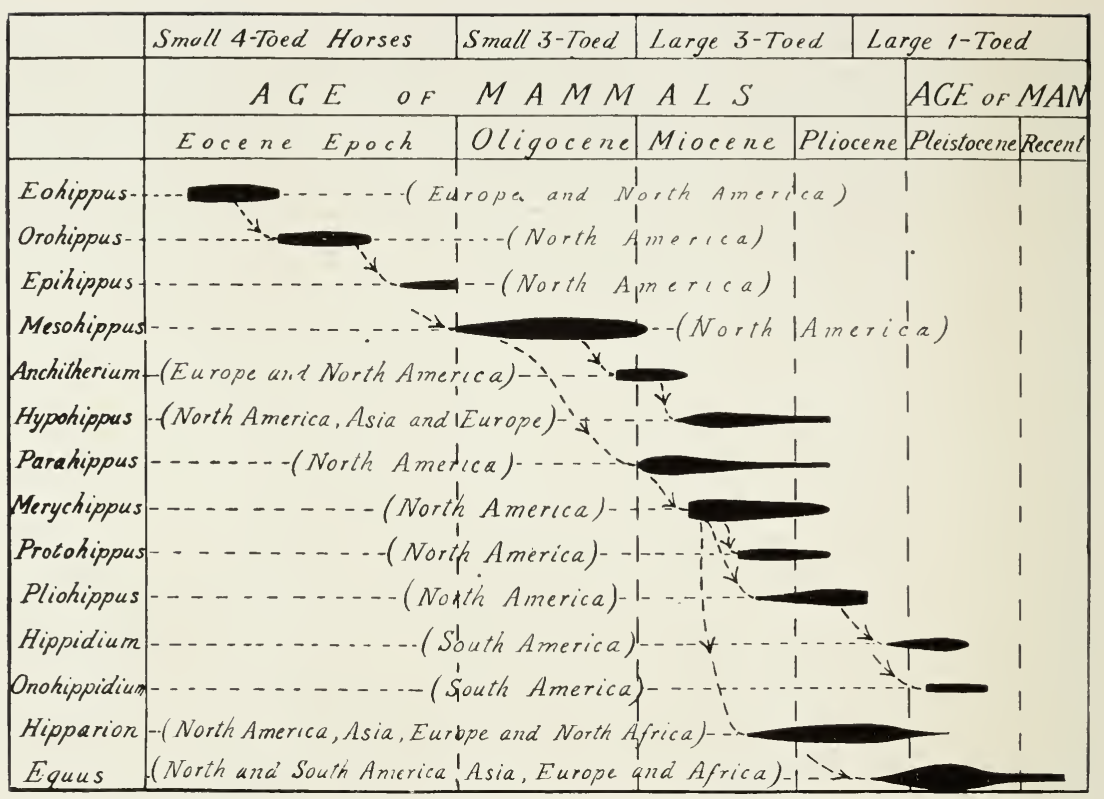

Fig. 16. Geological and geographical range of ancestors of the horse. The position and length of the heavy black lines show the oceurrence and range of each genus in the successive geologic epochs, while the thickness of the lines indicates relative abundance. The dotted connecting lines with arrows indicate the genealogy

\section{CONCLUSIONS}

$\mathrm{T}$

IIESE are the principal stages in the evolution of the modern horse from the little four-toed Eohippus. Intermediate between them are numerous minor stages, the earlier species of each genus being more primitive, the later species more advanced. The series of upper molar teeth shown in Figs. 19-20 show no wide differences from one stage to the next. But between most of them several intermediate species are known. This gradual change is seen not merely in one or few selected parts, but in every bone, every tooth, every portion of the skeleton. Elsewhere in the hall may be found similar although less complete series leading up from animals very close to Eohippus into the modern tapir and rhinoceros. The conclusion is unavoidable that horse, rhinoceros and tapir, three races widely different today, are derived through progressive changes from a common ancestral type. New species may have appeared suddenly, but the race in its broader lines is the product of gradual evolution, and diverse races may be traced back to a more ancient common stock. ${ }^{1}$

${ }^{1}$ Scientific eriticisms of "Darwinism" are concerned with the way in which new species have appeared, whether by infinitesimal gradations or by finite "mutations," appreciable although usually small steps. The broader lines of evolution are not affected by these criticisms. 


\section{MEANING OF THE CHANGE IN FEET AND TEETH}

LONG with the disappearance of the side toes in the evolution of 1 the horse there is a considerable increase in the proportionate length of the limbs, and especially of the lower part of the leg

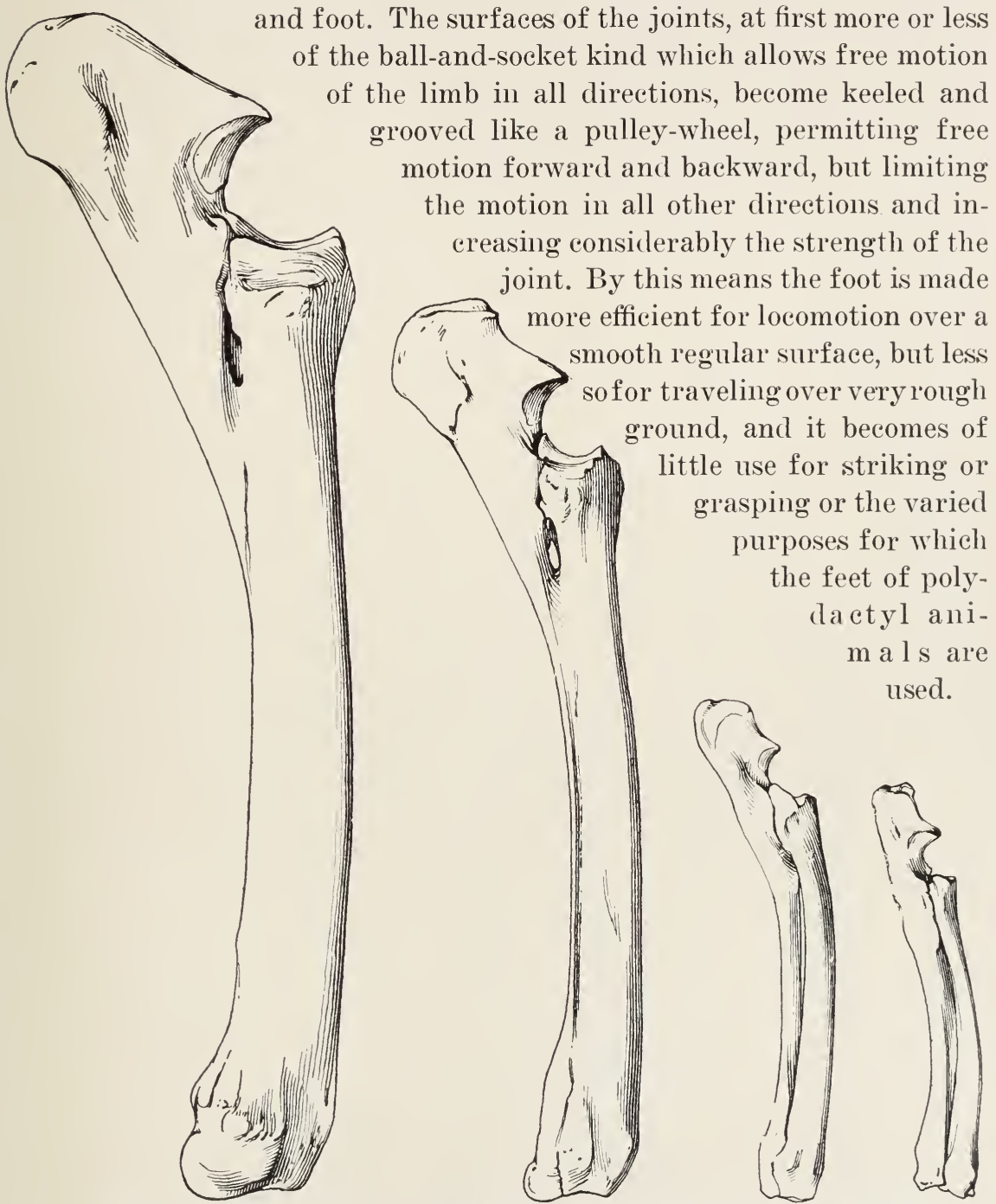

FIG. 17. EVOLUTION OF THE FORE I.EG. PRINCIPAI STAGES

Equus, Merychippus, Mesohippus, Eohippus

In the four-toed horses (Eohippus) the radius and ulna are separate and their shafts of about equal size. In the earlier three-toed horses (Mesohippus) the ulna is separate but its shaft considerably reduced. In the later three-toed horses (Merychippus) the ulna is partly consolidated with the radius and its shaft is reduced to a thin thread. In the one-toed horses (Equus) the ulna is more completely consolidated with the radius and its shaft has entirely disappeared 
The increased length in the lower leg and foot increases the length of the stride without decreasing its quickness. The heavy muscles of the leg are chiefly in the upper part, and to increase the length of the lower part changes the centre of gravity of the limb very little. Consequently the leg swings to and from the socket nearly as fast as before, since in an ordinary step the action of the leg is like that of a pendulum, and the speed of the swing is regulated by the distance of the centre of gravity from the point of attachment, as that of a pendulum is by the height of the bob. 'To increase the length of lower leg and foot therefore gives the
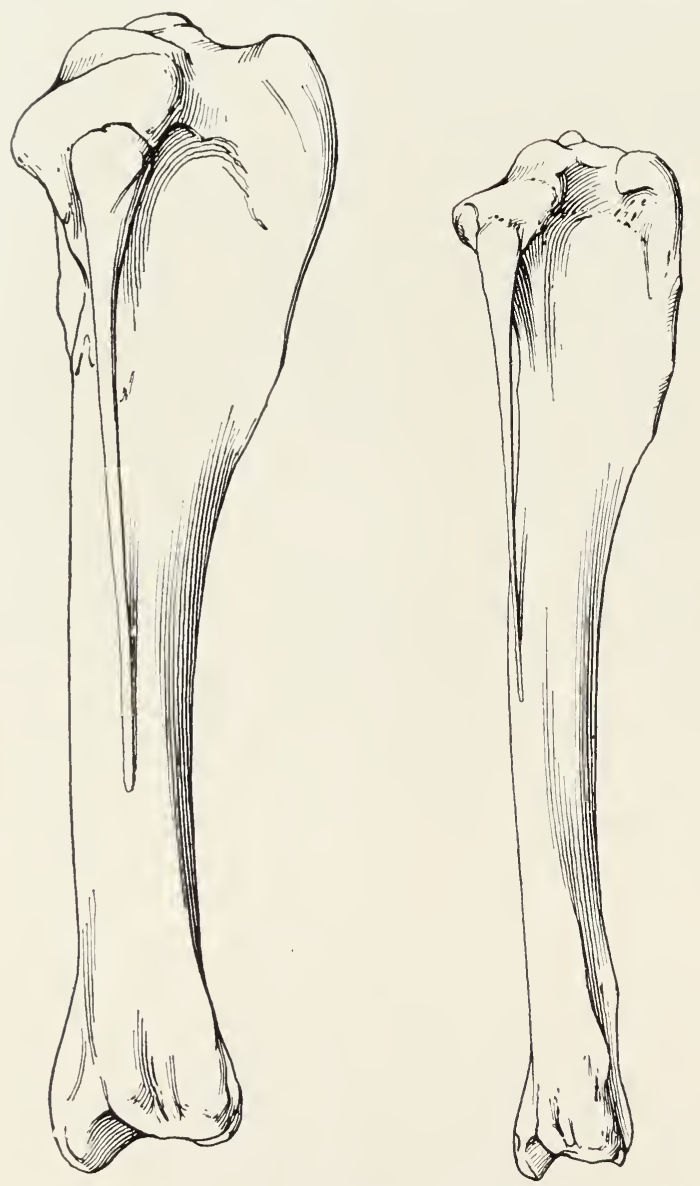
animal greater speed; but it puts an increased strain on the ankles and toe-joints, and these must be strengthened correspondingly by converting them from balland-socket joints to "ginglymoid" or pulley joints. Additional strength, likewise at the

FIG 18. EVOLUTION OF THE HIND IEG. PRINCIPAL STAGES

Equus, Merychippus, Mesohippus, Eohippus

In the four-toed horses (Eohippus) the fibula is complete and separate from the tibia. In the earlier three-toed horse (Mesohippus) it is very slender, and fused with the tibia from about the middle of the shaft down. In the later three-toed horses (Merychippus) the shaft of the fibula is incomplete and both ends are fused with the tibia. In the one-toed horses (Equus) the lower end is more thoroughly united so as to be indistinguishable from the tibia 

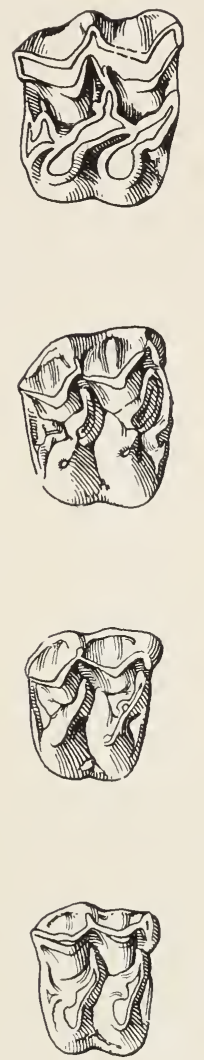

FIG. 19. EVOLUTION OF THE STAGES. Second Upper Molar (Read up). (1) Eohippus, Lower Eocene; (2) Orohippus, Middle Eocene; (3) Epihippus, Upper Eocene; (4) Mesohippus montanensis, Lower Oligocene; (5) Mesohippus bairdi, Middle Oligocene;

(6) Miohippus, Upper Oligocene;

(7) Parahippus, Lower Miocene
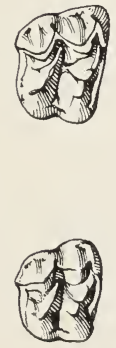

FIG. 20. EVOLUTION OF THE TEETH. IATER STAGES. Second Upper Molar

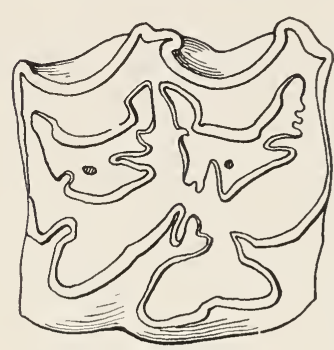

(Read up). (8) Merychippus, Middle Miocene; (9) Hipparion, Upper Miocene; (10) Equus stenonis, Pliocene; (11) Equus complicatus, Pleistocene; (12) Equus caballus, the modern horse
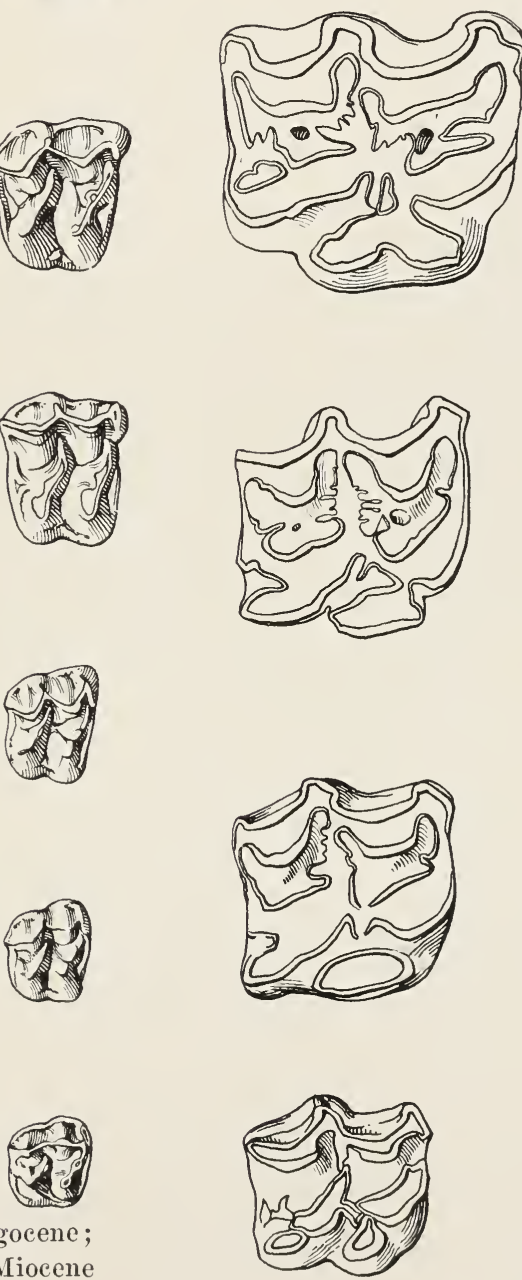
expense of flexibility, is obtained by the consolidation of the two bones of the forearm (ulna and radius) and of the leg (tibia and fibula) into one, the shaft of the smaller bone practically disappearing, while its ends become fused solidly to its larger neighbor. The increase in length of limb renders it necessary for the grazing animal that the head and reck should increase in length in order to enable the mouth to reach the ground. An example of these changes is the modern horse, in which we find the neck and head much elongated when compared with the little Hyracotherium and this elongation has taken place pari passu with the elongation of the legs. The reduction and disappearance of the side toes and the concentration of the step on the single central toe serve likewise to increase the speed over smooth ground. The soft yielding surface of the polydactyl (several-toed) foot is able to accommodate itself to a rough irregular surface, but on smooth ground the yielding step entails a certain loss of speed. A somewhat similar case is seen in the pneumatic tire of a bicycle; a "soft" tire accommodates itself to a rough road and makes easier riding, but a "hard" tire is faster, especially on a smooth road. Similarly, the hard, firm step from the single toe allows of more speed over a smooth surface, although it compels the animal to pick its way slowly and with care on rough, irregular ground.

The change in the character of the teeth from brachyodont or shortcrowned to hypsodont or long-crowned, enables the animal to subsist on the hard, comparatively innutritious grasses of the dry plains, which require much more thorough mastication before they can be of any use as food than do the softer green foods of the swamps and forests.

All these changes in the evolution of the horse are adaptations to a life in a region of level, smooth and open grassy plains such as are now its natural habitat. At first the race was better fitted for a forest life, but it has become more and more completely adapted to live and compete with its enemies or rivals under the conditions which prevail in the high dry plains of the interior of the great continents. The great increase in size, which has occurred in almost all races of animals whose evolution we can trace, is dependent on abundance of food. A large animal, as may be shown on ordinary principles of mechanics, requires more food in proportion to its size than does a small one, in order to keep up a proper amount of activity. On the other hand a large animal is better able than a small one to defend itself against its enemies and rivals. Consequently as long as food is abundant, the larger animals have the advantage over their smaller brethren, and by the laws of natural selection the race tends to become continually larger until a limit is reached, when sufficient food becomes difficult to obtain, the animal being compelled to devote nearly all its time to getting enough to eat. 


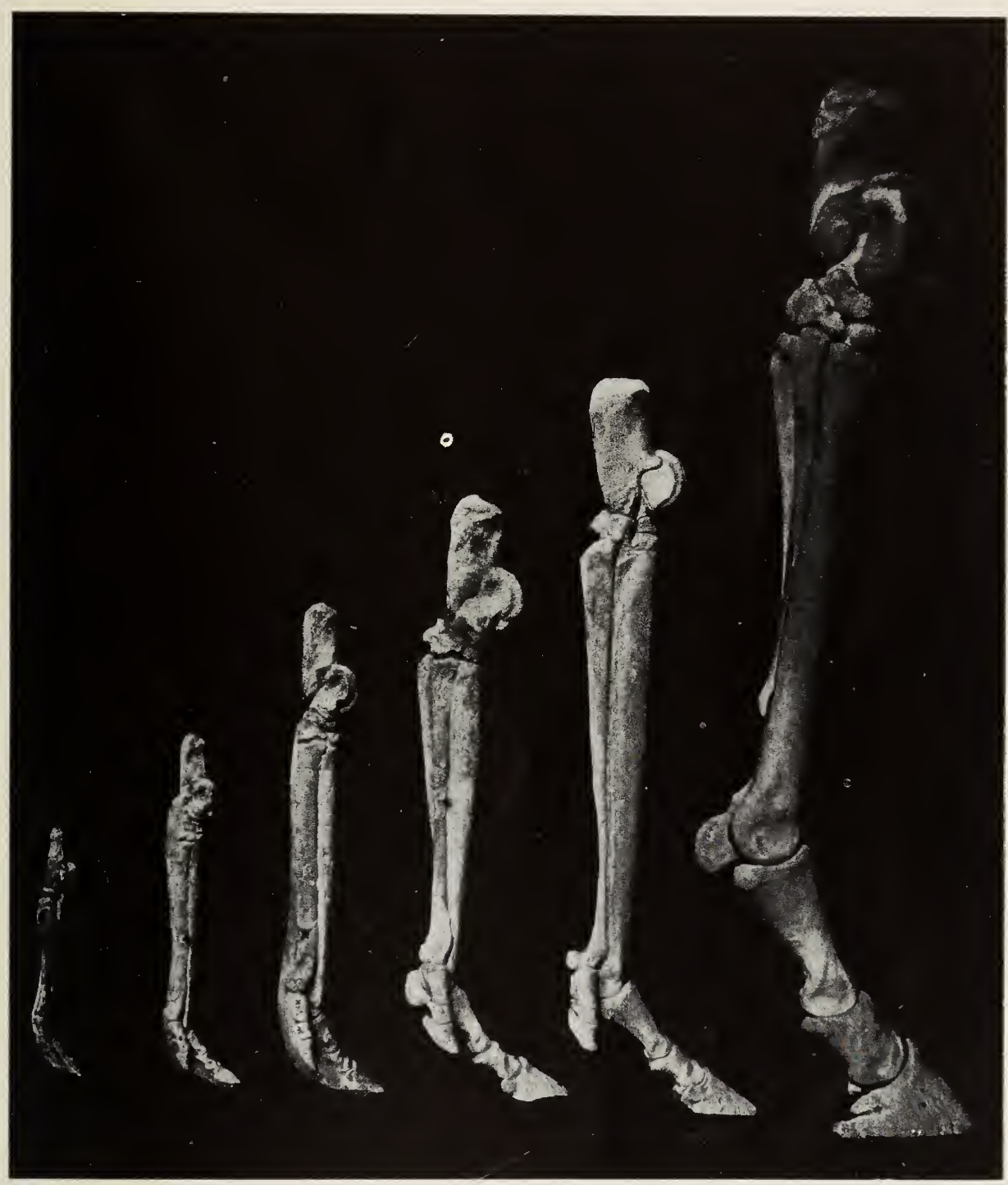

After Osborn

FIG. 21. EVOTUTION OF THE HIND FOOT OF THE HORSE

Side views of six stages, Eohippus, Mesolippus, Miohippus, Merychippus, Hipparion, Equus 


\section{CAUSE OF THE EVOLUTION}

$\mathrm{T}$ HE evolution of the horse, adapting it to live on the dry plains, probably went hand in hand with the evolution of the plains themselves. At the commencement of the Age of Mammals the western part of the North American continent was by no means as high above sea level as it now is. Great parts of it had but recently emerged, and the Gulf of Mexico still stretched far up the valley of the Mississippi. The climate at that time was probably very moist, warm and tropical, as is shown by the tropical forest trees, found fossil even as far as Greenland. Such a climate, with the low elevation of the land, would favor the growth of dense forests all over the country, and to such conditions of life the animals of the beginning of the mammalian period must have been adapted. During the Tertiary the continent was steadily rising above the ocean level, and at the same time other influences were at work to make the climate continually colder and drier. The coming on of a cold, dry climate restricted and thimmed the forests and caused the appearance and extension of open, grassy plains. The ancient forest inhabitants were forced either to retreat and disappear with the forests, or to adapt themselves to the new conditions of life. The ancestors of the horse, following the latter course, changed with the changing conditions, and the race became finally as we see it to-day, one of the most highly specialized of animals in its adaptation to its peculiar environment. At the end of the Age of Mammals the continents stood at a higher elevation than at present, and there was a broad land connection between Asia and North America, as well as those now existing. At this time the horse became cosmopolitan, and inhabited the plains of all the great continents, excepting Australia.

It is a question whether the direct ancestry of the modern horse is to be searched for in western America or in the little known interior plains of eastern Asia. It is also unknown why the various species which inhabited North and South America and Europe during the early part of the Age of Man should have become extinct, while those of Asia (horse and wild ass) and of Africa (wild ass and zebra) still survive. Man, since his appearance, has played an important part in the extermination of the larger animals; but there is nothing to show how far he is responsible for the disappearance of the native American species of horse. 


\section{PARALLEL EVOLUTION IN OTHER RACES}

$\mathbf{T}^{\mathrm{T}}$ is interesting to observe that while the evolution of the horse was progressing during the Tertiary period in North America another group of hoofed animals, the Litopterna, now extinct, in South America evolved a race adapted to the broad plains of Argentina and Patagonia and singularly like the horse in many ways. These animals likewise lost the lateral toes one after another, and concentrated the step on the central toe; they also changed the form of the joint-surfaces from ball-and-socket to pulley-wheel joints; they also lengthened the
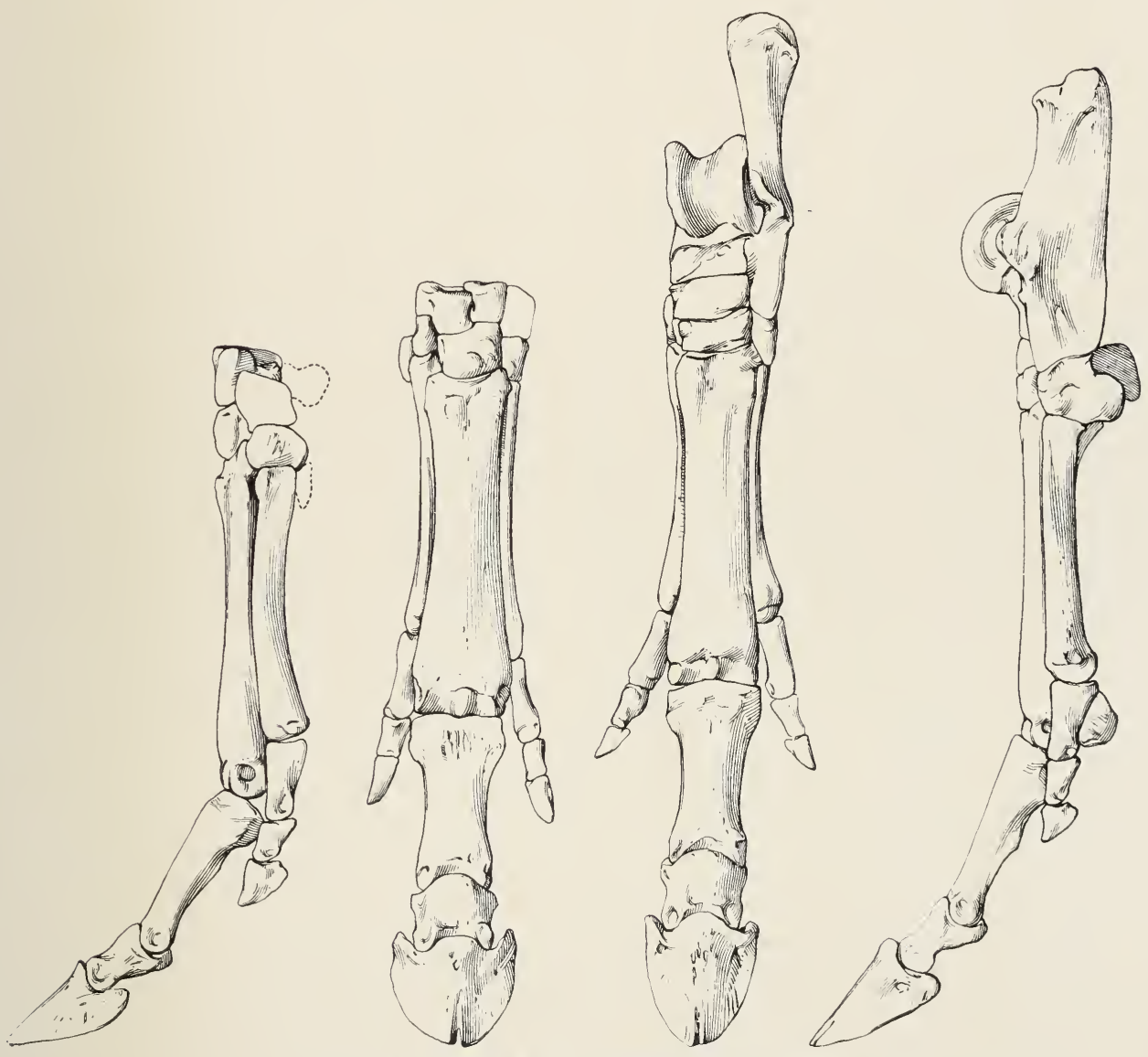

FIG. 22. THREE-TOED PSEUDO-HORSE

Fore and hind feet, one-half natural size. Diadiaphorus of the Miocene of South America, although so closely like the three-toed horses in the feet, has a wholly different skull and teeth, and belongs to a different order, the Litopterna, peculiar to South America and now extinct. From specimens in the American Museum 
limbs and the neck; and they also lengthened the teeth, and complicated their pattern. Unlike the true horse, they did not form cement on the tooth, so that it was by no means so efficient a grinder. This group of animals native to South America became totally extinct, and were succeeded by the horses, immigrants from North America, which in their turn became extinct from the appearance of civilized man.

Many of the contemporaries of the horse in the northern hemisphere were likewise lengthening the limbs, lightening and strengthening the feet, elongating the tooth-crowns to adapt themselves to the
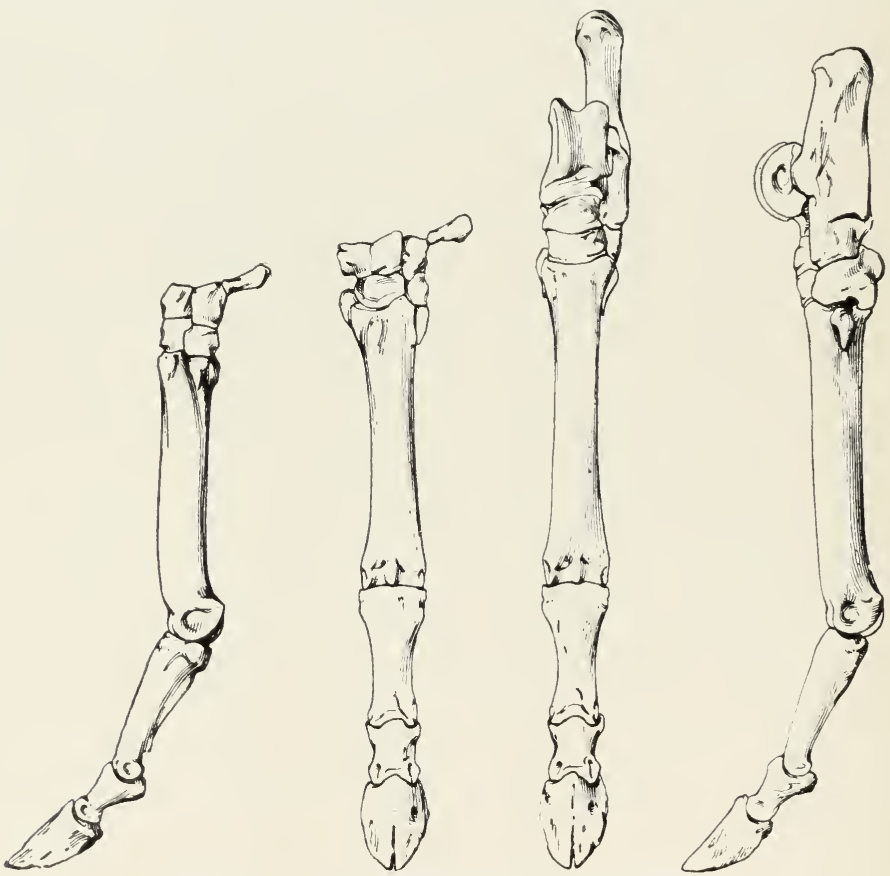

FIG. 23. ONE-TOED PSUEDO-HORSE

Fore and hind feet, one-half natural size. The Thoatherium has gone even further than the modern horse in redueing the side toes to tiny rudiments instead of splints. The skull and teeth show the animal to be closely related to Diadiaphorus (Fig. 22) and widely different from true horses. Thoatherium was a little larger than a fox terrier and lived in South America during the Miocene Epoch. From specimens in the Princeton Museum and the American Museum of Natural History

changing conditions around them, although none paralleled the horse evolution quite so closely as did the pseudo-horses of South America. But the camels in America, the deer, antelope, sheep and cattle in the Old World, progressed on much the same lines of evolution, although their adaptation was not to just the same conditions of life. 


\section{PRINCIPAL STAGES IN THE EVOLUTION OF THE HORSE Synoptic Panel}

In the Horse Alcove is a double panel (pages 36 and 37 , somewhat altered in the present arrangement) showing the chief stages in its evolution. On the right-hand panel is the series of skulls, fore feet and hind feet, each stage set opposite the geological epoch during which it lived. Thus all horses found as fossils in the rocks of the Eocene Epoch are Four-toed Horses; all from the Oligocene are small Three-toed Horses with short-crowned teeth, and so on.

On the left-hand panel is a corresponding series of palates to show the gradual change in pattern of the upper teeth, and conversion of the premolars into "molariform" grinders; and a series of single teeth to show the progressive lengthening of the crown. The change in the brain, the fore leg and hind leg are also shown in this panel, and side views of the fore and hind foot show more clearly the stages in reduction of the side toes.

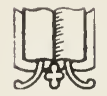




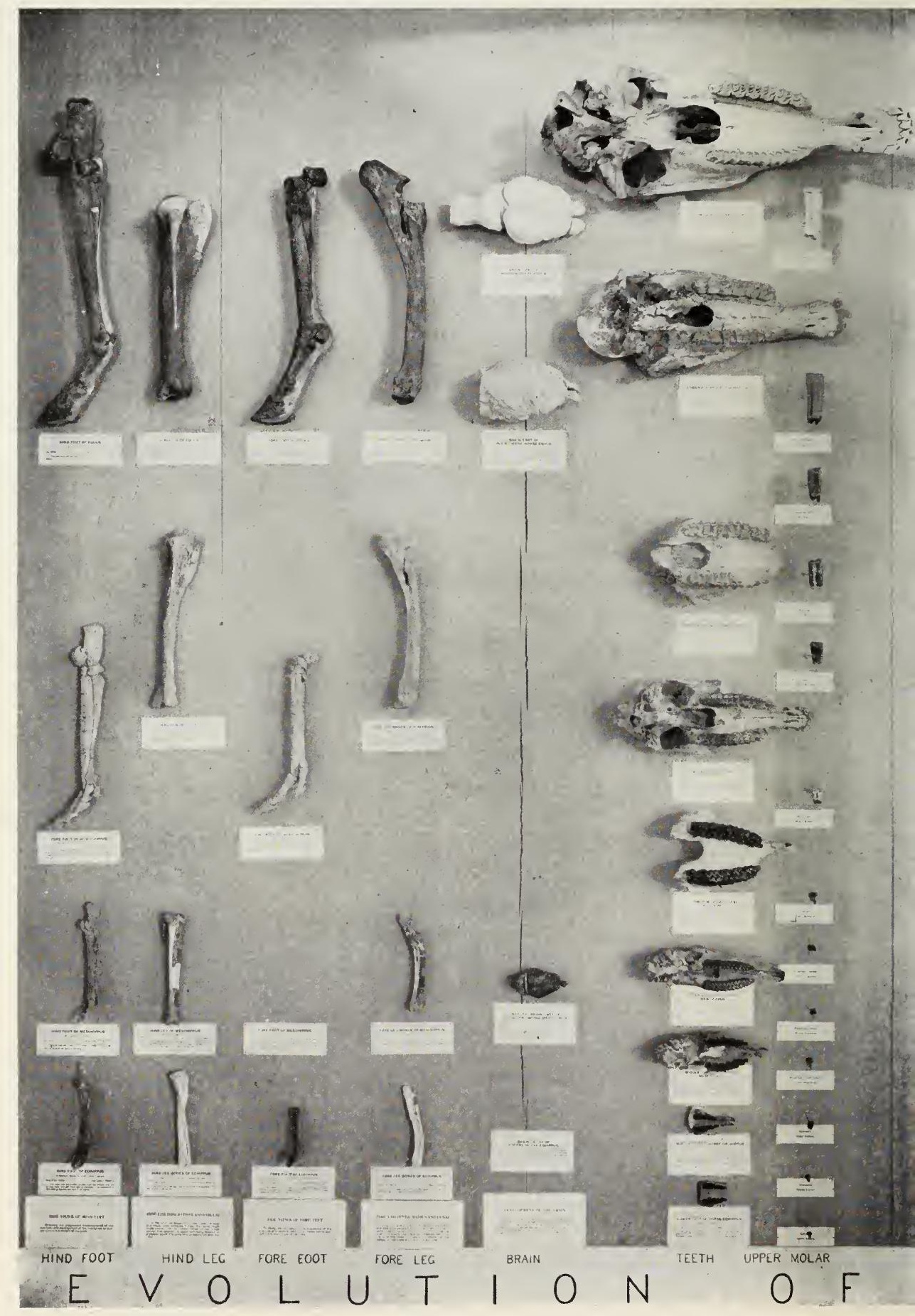




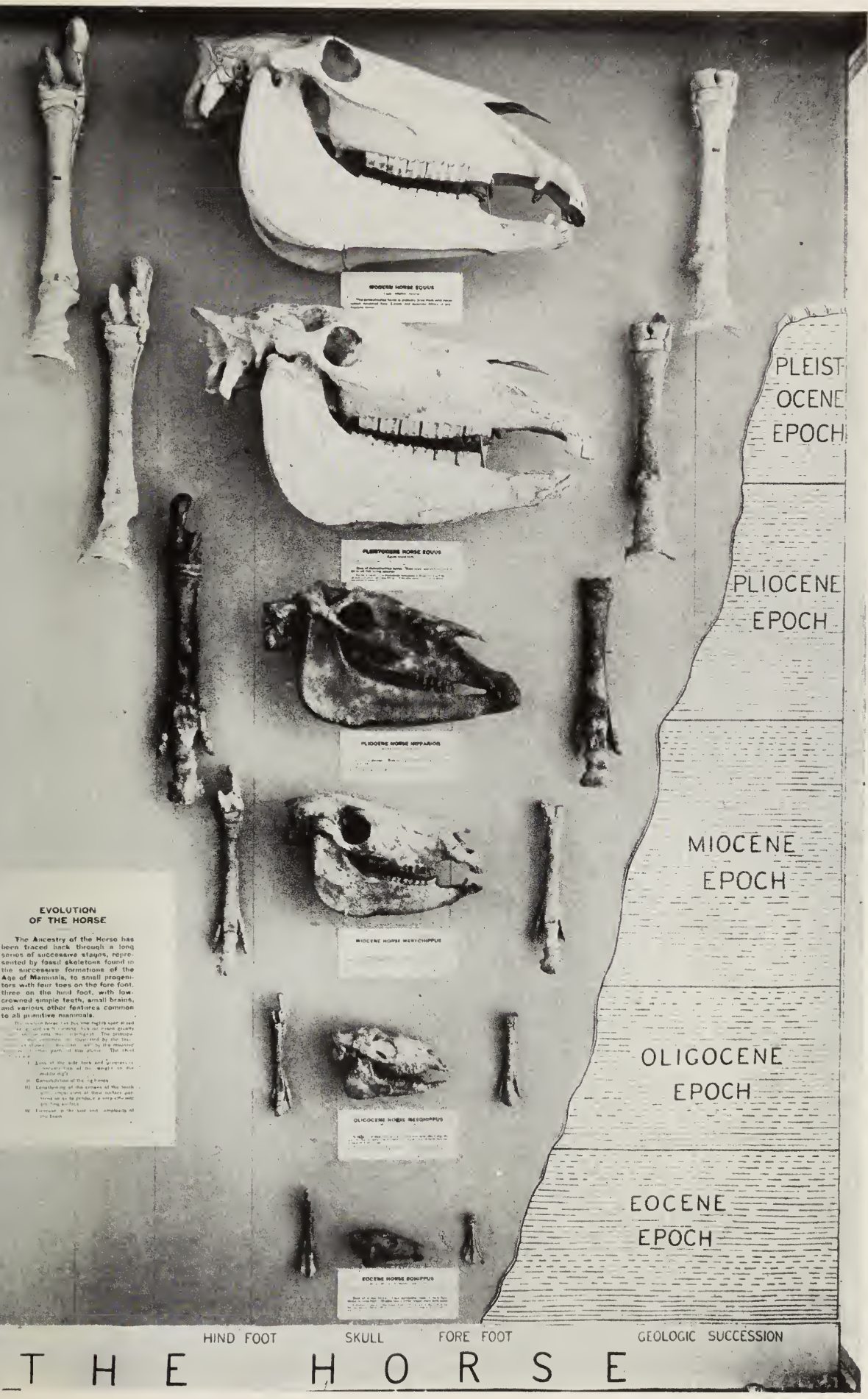




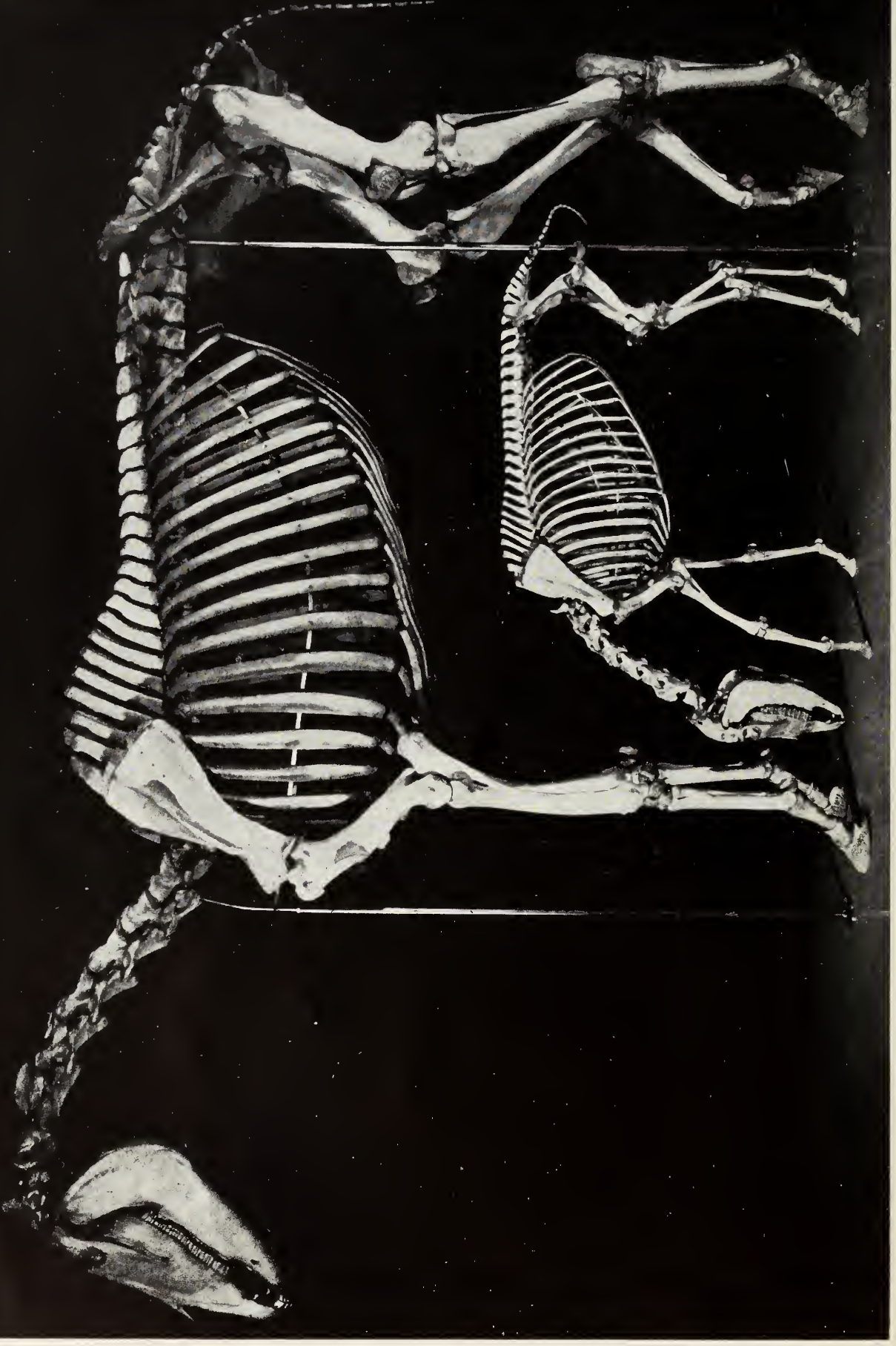

年 


\title{
Part II. THE HORSE UNDER DOMESTICATION ITS ORIGIN AND THE STRUCTURE AND GROWTH OF THE TEETH
}

\author{
By S. Harmsted Chubb \\ Associate Curator of Comparative Anatomy \\ Skeletons Mounted by the Author
}

W

HEN animals are living under perfectly natural conditions, their physical structure is slowly modified by climate, topography of habitats, and food supply as well as by many other forces. In the struggle for self-preservation among the competitors by which they are surrounded, they develop weapons of defence, or acquire speed mechanism or other means of escape. Thus what we may call natural, as opposed to artificial evolution, is controlled by a great variety of forces, while in a condition of domestication we have development directed in certain lines by man's intelligence.

\section{ORIGIN OF THE DOMESTIC HORSE}

I $\mathrm{N}$ the light of researches made by Professors Ridgeway, Osborn, and Ewart, there seems to be little doubt that the domestic horse has been derived from several wild types which have since become extinct as wild species. Of two at least we may be reasonably sure: one of Europe or northwestern Asia, which has been called the Norseman's horse; the other from northern Africa, which Professor Ridgeway has called Equus libycus.

There is abundant evidence to prove that in the late Quaternary, during and after the Glacial Period, but nevertheless many thousands of years ago, prehistoric man chased and killed wild horses, using their flesh for food and possibly their skins for raiment. This period was followed by a second, during which wild horses were captured, broken to rude harness and driven. The rearing action of the horse skeleton in the group on exhibition in the Museum (Frontispiece) is designed to express unwilling subjection, and the position of the man, as if holding a bridle, intellectual control. The period of early domestication passed insensibly into a third, that of artificial development, during which the horse was modified, and is still being changed in various minor details.

Under man's protection and management, changes are brought about in domestic animals with considerable control and much more rapidly than under perfectly natural conditions. Through training and careful selection in breeding, speed has been greatly increased in the race horse, weight and strength have been developed in the draft horse, while the Shetland pony has been reduced to a most diminutive size. 


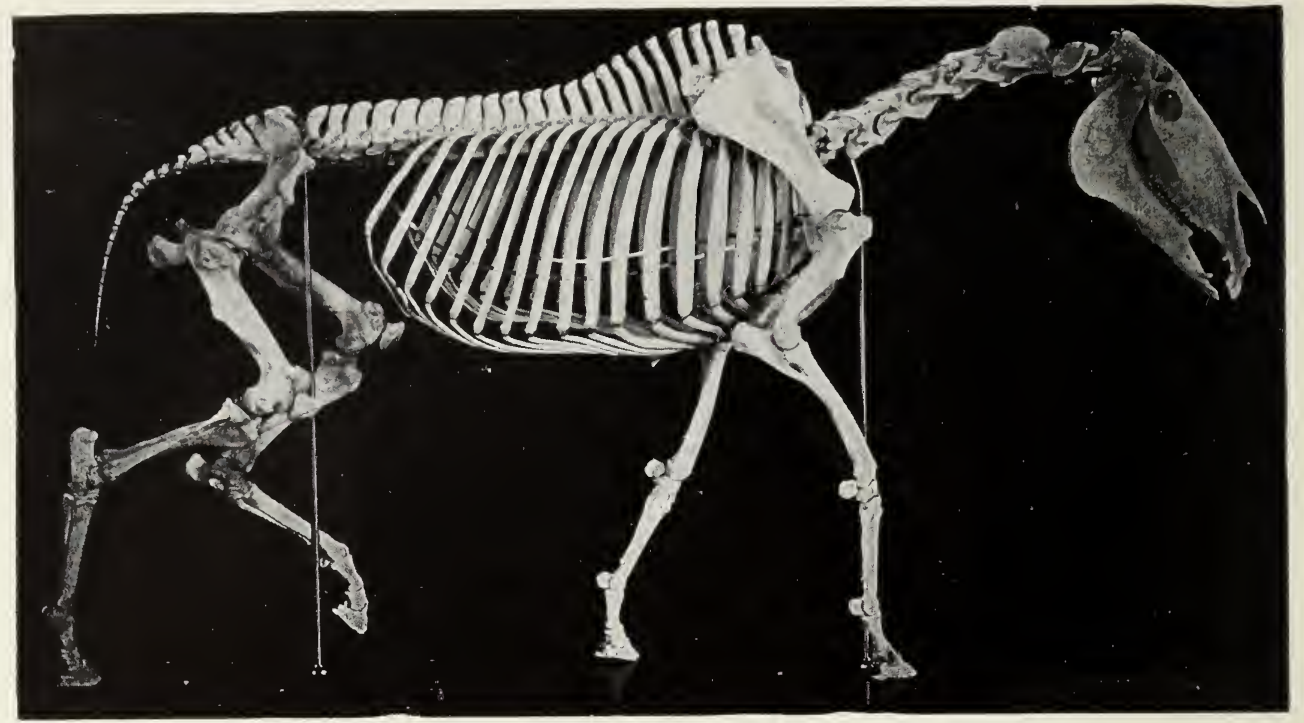

FIG. 26. THE DRAFT HORSE PUIIING A HEAVY LOAD

Funds for the preparation, a gift of William C. Whitney. The subject from which the skeleton was prepared and presented by Mr. George Ehret

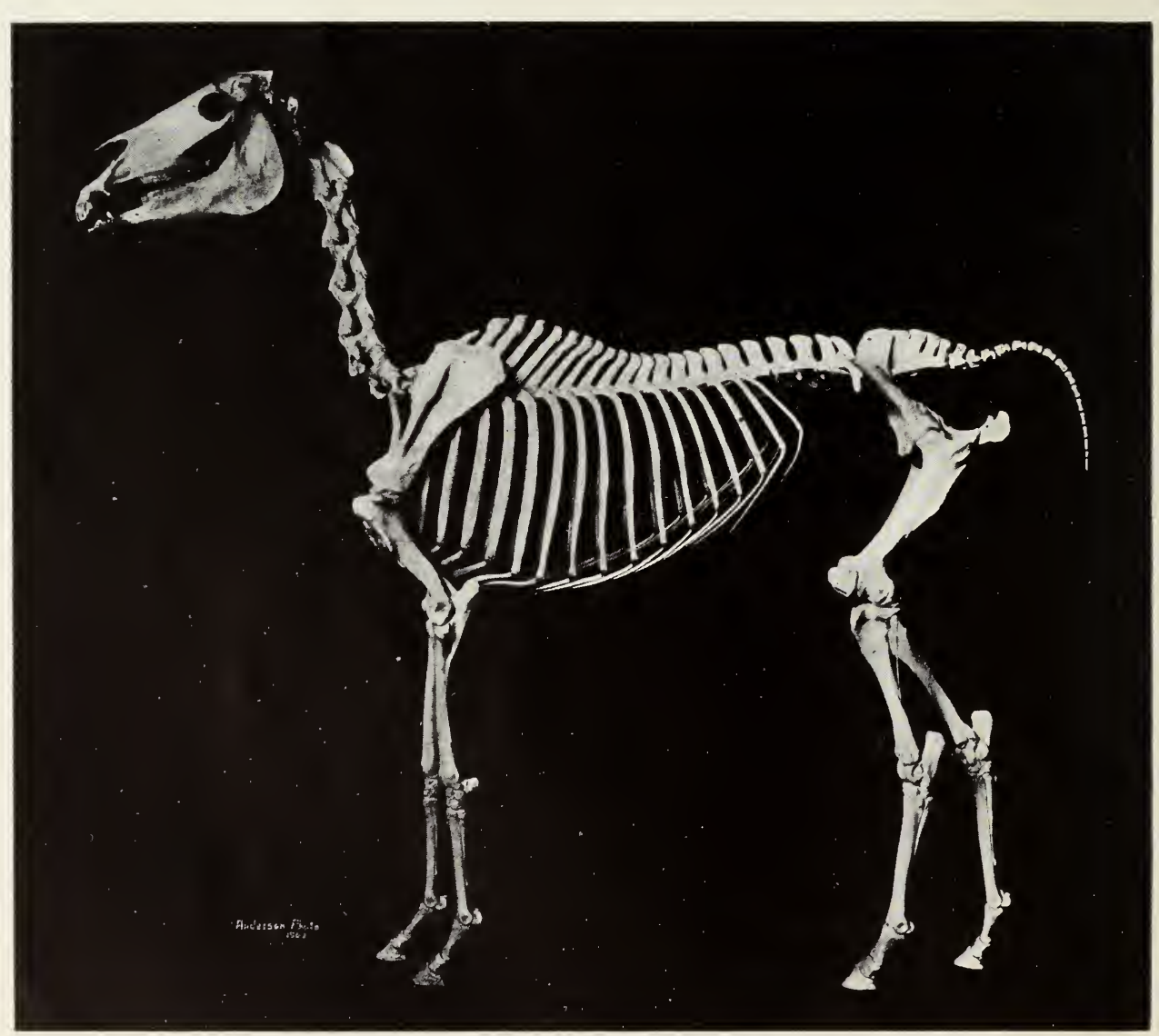

FIG. 27. ARABIAN STALIION, "NIMR"

Nounted in the position of watching a herd. Subject presented by Mr. Randolph Huntington 
The intimate relations which have thus existed between the horse and man have influenced both, and it is generally acknowledged by students of mankind that the subjugation of the horse and his adoption, both as a means of transportation and as an aid in agriculture, have been factors of the greatest importance in the later development of the human race.

\section{COMPARISON OF THE SKELETONS OF THE HORSE AND OF MAN}

W

HHLE considering these two skeletons (Frontispiece), it will be worth while to look for a moment into their structure. They are so placed as to facilitate comparison. The one representing a typical or average type of horse, the other a man of about six feet in height and proportionately heavy. The limbs of the horse, moving only forward and backward, have much less freedom of motion than have those of man. Note the ball-and-socket joint of man at the shoulder and hip, the rotary motion of the forearm and the flexibility at the wrist and ankle, and compare with the restricted movement at the shoulder of the horse, the hingelike joint at the elbow, and the limited movement at the wrist (knee) and ankle (hock). The most pronounced differences, however, are found in the head and feet. Compare the skull of man, which has an enormously developed brain and reduced facial portion, with that of the horse which has a comparatively small brain, the face, mouth, and teeth monopolizing almost the whole skull. The feet, instead of having five toes as in man, are reduced to a single digit ${ }^{1}$ and they are very much elongated as a speed specialization. And yet a careful study will reveal a most striking similarity between the two subjects in general structure, the differences being simply modifications of a common plan.

\section{THE DRAFT HORSE}

$\mathrm{T}$

HE Norseman's horse of Europe seems to have been an animal with large head, convex forehead and rough coat, of rather clumsy appearance, and of comparatively little speed. It may have been a near relative of Przewalsky horse which still lives as a wild species in northwestern Mongolia, the only true wild horse known at the present time, the so-called wild horses of the New World being the descendants of domestic horses brought over by the Spaniards during the early settlement of America. Among other evidences of this prehistoric Norse horse, are the many sketches found in the south of France and elsewhere, made by the very primitive cave-dwellers, which seem clearly to depict this type of horse, and it is no doubt this strain which pre-

${ }^{1}$ See page 22. 


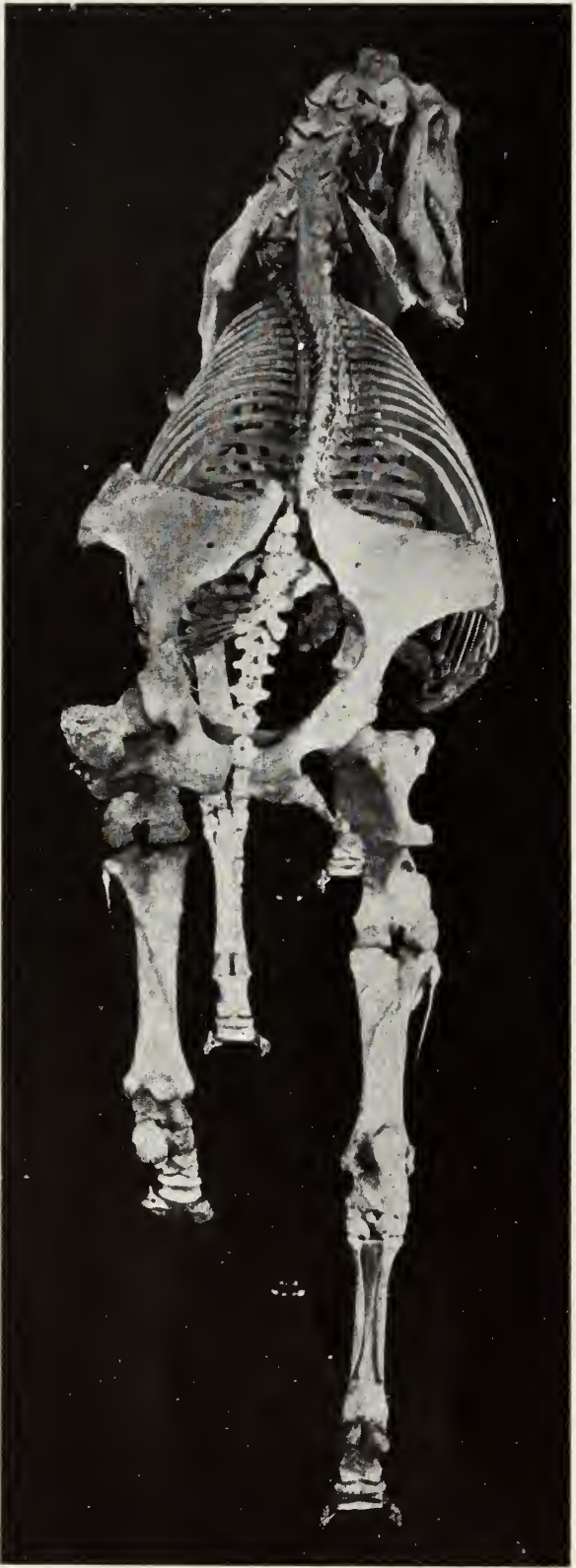

FIG. 28. THE DRAFT HORSE Rear view showing action of pelvis and backbone reversed, and the pressine is again applied (this time from the left) along the main axis of the body as before; and so on from step to step. dominates in our heary draft horse of to-day although of course this horse has been greatly increased in size and strength by long and eareful breeding.

An attempt has been made to express the strength acquired in this breed in the mounted skeleton of the draft horse (Fig. 26). This skeleton has been so mounted as to show the action of the bones when the animal is drawing a heary load. We inust imagine that the shoulders rest against a collar upon which the horse is exerting its energy. Note that the head and body are lowered, the hind legs are doing the greater amount of work, the fore legs acting as supports, though a portion of the weight of the body has been thrown against the collar. From the rear view (Fig. 28) note that the right hip joint is much nearer the median line than is the left. The joint is also lower,and indeed,theentire right side of the pelvis has been low(reed and thrown well to the left, so that when at the moment of greatest strain the right leg is extended, the pressure upon the anterior part of the body, and thence upon the eollar, is a pplied in a line which more nearly coincides with the main axis of the body. At the next moment the left leg is supposed to be exerted, the right is released, the pelvis then swings to the right, the curve in the backbone becomes 


\section{DEVELOPMENT OF GREAT SIZE IN THE DRAFT HORSE}

$\mathrm{T}$

HE skeleton of a very large draft horse is exhibited to show the extreme development of size in this breed. It has been photographed with the skeleton of a Shetland pony to show two extremes in domestic horses (Fig'. 25). The following is a table of measurements of the two specimens.

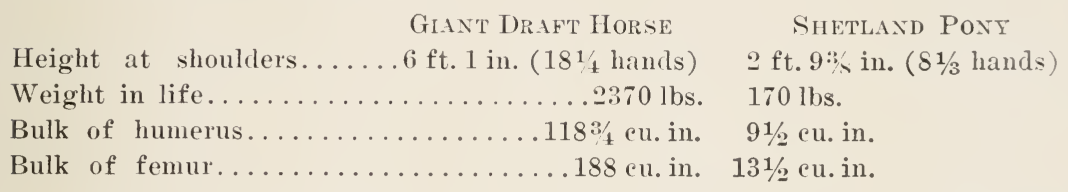

The pose chosen for the mounting of this specimen is one of inaction designed to express quiet restfulness, in contrast to the running action of the race horse, to be mentioned later. It shows also a habit peculiar to horses, that of alternately resting the hind legs. Almost the entire weight of the hind quarters is supported on the extended left leg, while the right hind leg rests in a more flexed position and hangs perfectly lax. The pelvis also seems to hang, as it were, from the left hip joint, tilting very much to the right and slightly twisting the vertebral column.

A peculiar function of the patella (kneecap) in the horse is shown in the left knee joint or stifle. While the limb is extended and supports the animal's weight, the patella rests on a projecting articulation of the femur, so that the knee is locked in an extended position by a very strong ligament which holds the patella at a fixed distance from the tibia below, thus sustaining the weight required of it with comparatively little muscular exertion.

An abnormal peculiarity of this specimen is a pair of superuumerary molar teeth, which appear at the posterior end of the upper set. Having no opposing teeth in the lower jaw upon which to wear, they have protruded down into the gum and must have caused the animal considerable discomfort.

\section{THE SHETLAND PONY}

$\mathrm{I}$ $\mathrm{T}$ is highly probable that the Shetland pony is derived from practically the same wild stock as the very much larger draft horse, but has been reduced in size by adverse conditions to which it was subjected in the cold and barren Shetland Islands with their limited area, and also by having been systematically bred for the smallest possible size.

Figure 25 shows the skeleton of an exceptionally small pony which was secured through the Whitney fund. 'This pony was bred in Scotland and obtained through the kindness of Professor J. C. Ewart of the Uni- 
versity of Edinburgh. The skeleton represents the grazing action. It will be seen that the downward reach of the head and the slow, lax step modify the position of almost every bone in the body.

The vertebral column is considerably arched in the dorsal region, as a result of the downward curve of the neck. This arehing of the back at the same time tilts the angle of the pelvis a few degrees toward the perpendicular, which slightly raises the hind quarters and tilts the body toward the head, thus enabling the teeth to reach the grass with greater ease. The head being turned well to the right, there is a very slight curve toward the left in the anterior portion of the dorsal vertibræ, and a slight curve to the right in the lumbar vertebræ owing to the backward position of the right hind foot.

The weight of the body falls on the right front and left hind feet, bringing them both very near the median line, and also modifying the position of the scapula and elevating the left side of the pelvis. A little below the left knee a very small hairlike bone may be seen, which represents the shaft of the almost extinct fibula, a bone which was well developed in the ancestors of the horse.

\section{THE ARABIAN HORSE}

$\mathrm{O}$ $\mathrm{F}$ all the many types of horses probably the one most universally admired and loved is the Arabian, with its marvelous grace and beauty, great intelligence, perfection of anatomical mechanism, fleetness, and endurance. The question may well be asked, whence comes this superiority?

The great fondness and care with which the Arabs have bred their horses for many hundreds of years have undoubtedly done much for the elevation of the stock; but more than this it is shown almost conclusively that the Arab was blessed with a wonderfully fine natural species on which to exercise his care. On this point Professor William Ridgeway, of Cambridge University, has given us an immense mass of most convincing evidence. ${ }^{1}$

There are many reasons, traditional and historical, as well as zoological, for believing that the Arabian horse, or as Professor Ridgeway has called it, the Libyan horse, is in origin entirely separate from the very much inferior northern or Norseman's horse, and that its native home was not in Arabia but northern Africa, where it was domesticated by the ancient Libyans, in all probability as early as 2000 B.c.

${ }^{1}$ Ridgeway, William. Origin and Influence of the Thoroughbred Horse. Cambridge: Univ. Press, 1905. 
The Egyptians also knew full well the value of domestic horses. "Egypt was, in fact, famous for its breed of horses which were not less excellent than numerous, and we find that they were even exported to other countries, Judea, Syria, and to the Kings of the Hittites." It is also clear, from Egyptian art, that these horses were of the North African, or as we would say to-day, Arabian type. It has been the constant infusion of this Libyan blood which has tended to improve our commoner horses for these many centuries.

The skeleton of Nimr (Fig. 27), a pure-blooded Arabian stallion, has been mounted to show some of the conspicuous characteristics of this species, which are as follows:

1. Head and tail carried high when the animal is animated;

2. Skull short, but broad between the eye sockets;

3. Eye sockets high and prominent, giving the eyes a wide range of vision;

4. Facial profile, or forehead, concave;

5. Muzzle slender, but jaw deep and wide above the throat;

6. Round thorax, well "ribbed up" and short back with only five ribless, or lumbar vertebræ;

7. Horizontally placed pelvis (a speed character) and very high tail region, few tail vertebræ;

8. Long and slender cannon bones and long sloping pasterns. ${ }^{2}$

Nimr was sired by the desert-bred Arabian, Kismet, famous for an unbroken series of victories as a race horse in India. After his death at Oyster Bay, Long Island, in 1904, the remains were presented to the Museum by the owner, Mr. Randolph Huntington.

\section{THE RACE HORSE}

$\mathrm{A}^{\mathrm{s}}$ $\mathrm{S}$ for the earliest domestication of the horse in Britain, where the race horse or thoroughbred has since been developed, no definite statement can be made. We read that horsemen in large numbers opposed the landing of the Romans, and also that in 631 A.D. the English first began to saddle their horses. Again we find mention of "running"' horses in the ninth century. But it was not until about 1689 , when the famous Byerley Turk was brought to England, that we learn anything definite concerning the origin of the present English stock, though horses of undoubted North African blood had been imported from Turkey a century or more earlier.

The Darley Arabian, bred in the desert of Palmyra, was imported into England by Mr. Darley in 1705. About twenty years later the

${ }^{1}$ Wilkinson, I. G. Ancient Egyptians.

${ }^{2}$ Osborn, H. F. Points of the Skeleton of the Arab Horse. Bull. Amer. Mus. Nat. Hist., vol. xxiii, art. 13, pp. 259-263, 1907. 


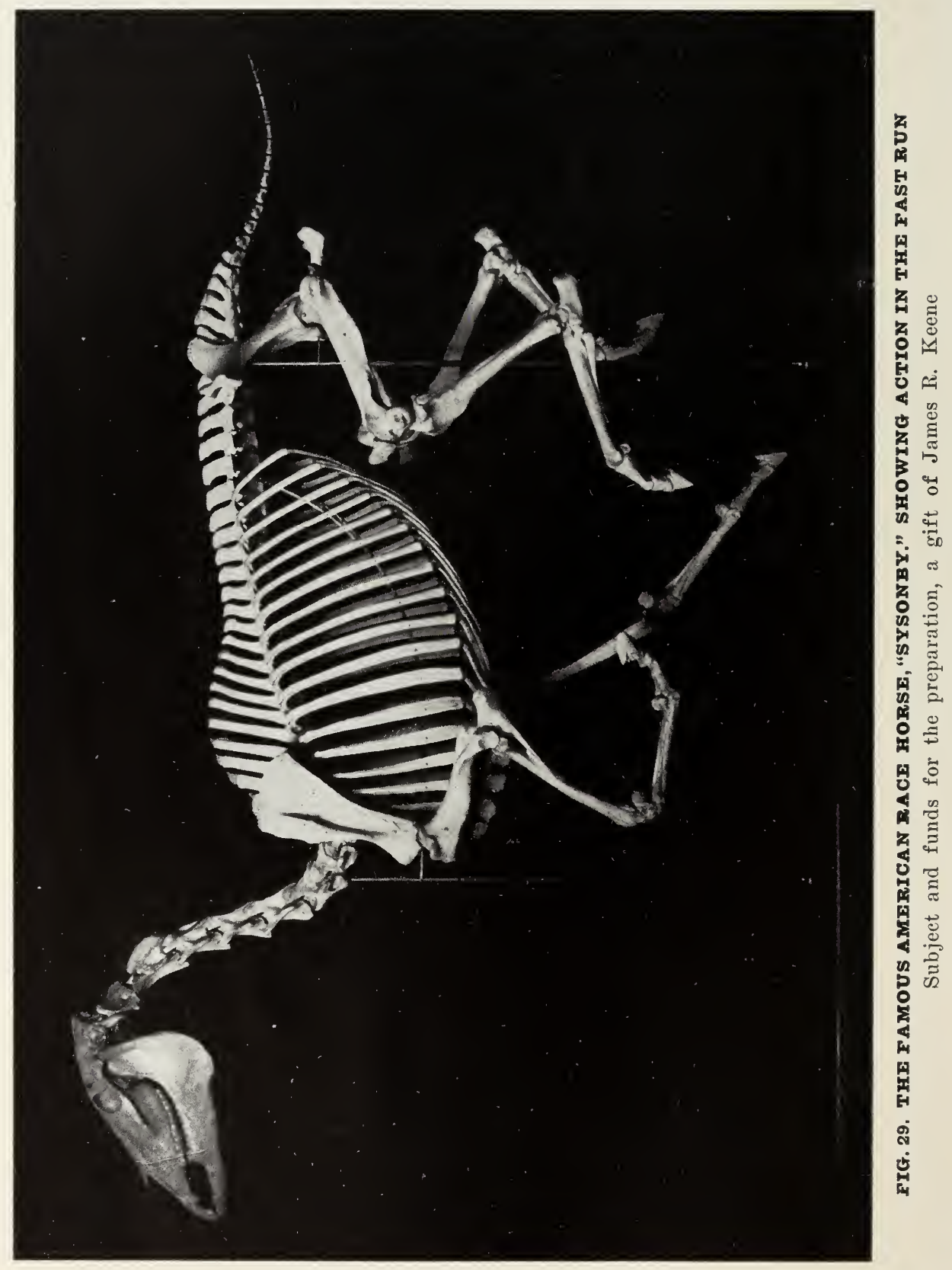


Godolphin Arabian ${ }^{1}$ arrived on the seene, continuing to improve the English stock with infusion of North African or Libyan blood, to which the quality of the race horse is chiefly due.

Touchstone states, "The thoroughbred, as soon as he ceases to be subjected to the special régime of training, reverts to the Arab type with such extraordinary rapidity that we eannot be blind to the fact that he descends, for at least seven parts out of eight, from the pure Arab," which we would consider of Libyan origin; and indeed many admirers of the Arab would gladly eliminate the remaining eighth of non-Arabian blood.

However, the race horse of to-day is a very highly specialized animal, certainly vastly different in appearance from the Arab and yet still more widely separated from the draft-horse type.

In July, 1906, we were particularly fortunate in the gift from Mr. James R. Keene of the remains of one of America's most famous race horses, together with sufficient funds for the preparation of the skeleton.

This remarkable horse, Sysonby, was foaled February 7, 1902, at Mr. Keene's Castleton stud in Kentucky, a few months after the importation from England of his dam, Optime, his sire being the English bred Melton. His record, at the time of his death, was one of the most brilliant in the history of American horse-racing. He won a remarkable series of victories between his first race at Brighton Beach, July 14, 1904, as a two-year-old, and his untimely death at four years, July 17, 1906.

The skeleton (Fig. 29) has been mounted to show a phase in the stride of the running horse, and is based on studies made from direct observation and instantaneous photographs. The position is that of the moment after the right fore foot has left the ground, and the right "knee," or carpus, is beginning to bend; the succeding footfalls in order are the left hind, the right hind, the left fore, and the right fore, the full length of one complete stride being about twenty-five feet.

At this instant the hind quarters are lifted perceptibly higher than the shoulders and from a rear view it will be seen that while the hind feet are thrust forward at this greater height from the ground, they are widely separated so as to avoid striking the fore legs. A moment later the shoulders will be lifted by the push of the fore feet higher than the hind quarters, then the hind feet will move toward the median line and strike the ground, and the fore feet will have moved forward out of the way of the hind. While in Fig. 29 the two left feet are moving in advance of the right, this order is often reversed, resulting in a right lead.

${ }^{1}$ Richard Berenger, however, denies that this horse was an Arab, though his view is not generally accepted. History and Art of Horsemanship, 1771.

${ }^{2}$ Touchstone, S. F. Race Horses and Thoroughbred Stallions. 
The backbone is slightly arched to help draw together the fore and hind feet. Then the back muscles are brought into action straightening the spine and thus lengthening the stride. When viewed from above, or from the rear, the backbone is also observed to be curved a little to the right, owing to the forward position of the left side of the pelvis and of the left hind limb. As the left foot moves backward the spine is straightened laterally and then the curve reversed, thus further contributing to the power and length of the stride.

\section{THE RUSSIAN WOLFHOUND COMPARED WITH THE RACE HORSE}

$\mathrm{T}$ HE skeleton of a Russian wolfhound (Fig. 30) has been mounted to show a most extreme action in the progressive movement, and also to make a comparison between the running action of the horse and of the dog. To facilitate this comparison, the moment in the stride which has been selected for the preparation of this specimen is approximately the same as that chosen in the case of the running horse, Sysonby. The two skeletons also furnish an interesting example in comparative osteology.

With the exception of a few peculiar and highly specialized forms, the laws governing animal locomotion among terrestrial mammals are practically the same. Certain principles are strictly adhered to by animals so diversified, for instance, as the horse, the squirrel, or the mouse.

Nearly all mammals have three natural gaits, the walk, the trot, and the run. These respective methods of locomotion vary so slightly in different animals that it will be interesting to point out some of the minor differences. The dog, a much smaller animal yet approximating the horse in speed, must necessarily acquire a much more extreme action than does the horse, but the differences are mostly matters of degree. For instance, at the moment when the limbs are drawn together the spine of the hor'se is slightly arched. Compare this with the very strongly curved back of the dog. And while the hind toe of the horse comes in line with the pastern of the front foot, the limbs of the dog cross not far from the knee of the hind leg and the elbow of the front. It is also found that when the horse is running at full speed he is entirely free from contact with the ground approximately one-fourth of the time, that being the moment when the limbs are drawn together under the body, while the dog is suspended in air about one-half of the time, being free from the ground twice during each stride, once when the limbs are drawn together and again during the extended position. 


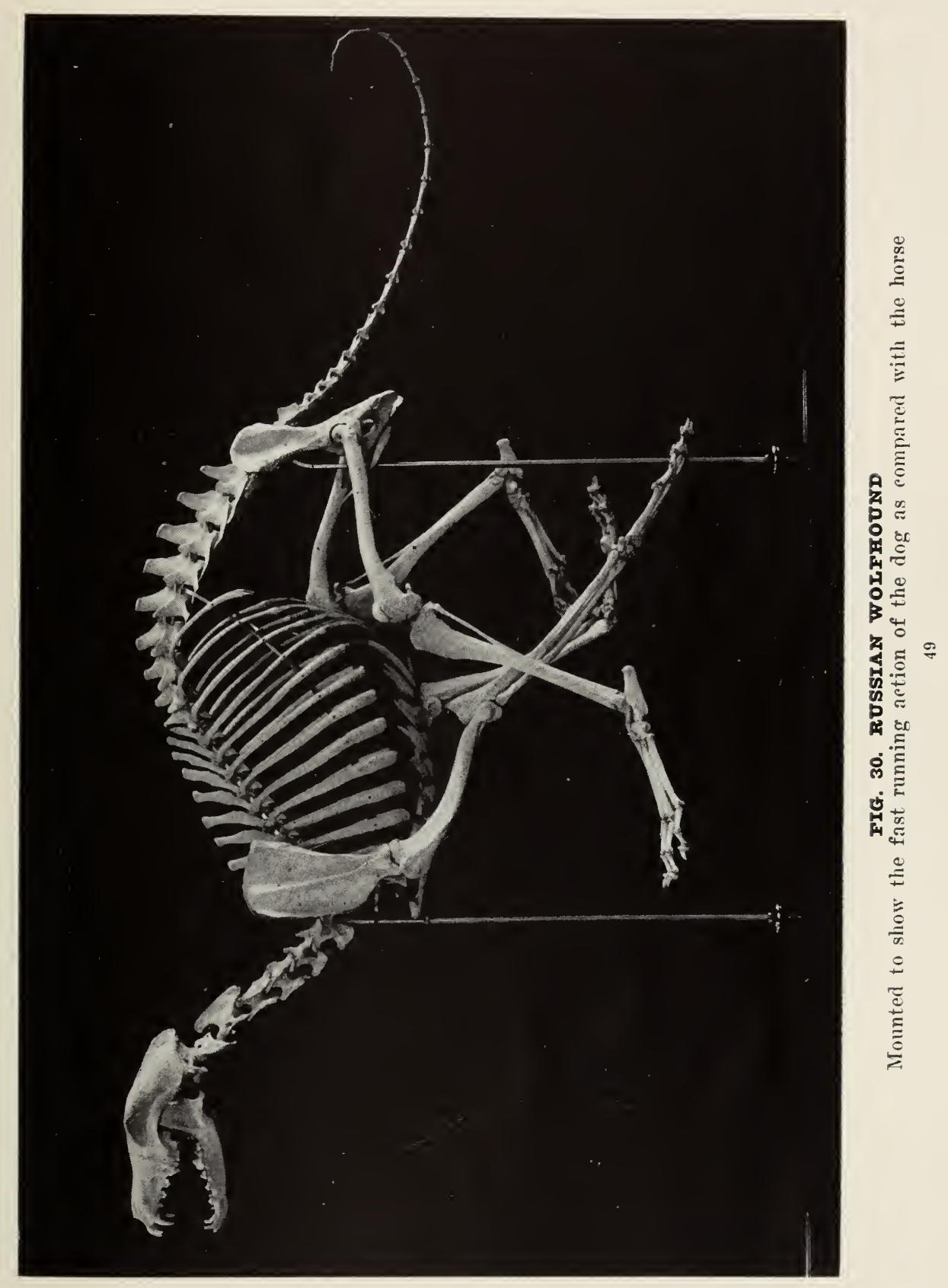


There is, however, one technical difference between the running action of the horse and that of the dog, that of the succession of footfalls. Let us compare the action represented by these two skeletons. In each ease, the next foot to strike the ground will be the left hind foot and then the right hind, but the horse will follow the right hind foot with the left front, and then the right front foot. Hence it may be called the diagonal rum.

The dog, on the other hand, prefers the rotatory run, striking the right front foot after the right hind, and so on around, so that at the moment when the limbs are drawn together under the body the two which come more nearly in contact with each other are those of the same side, while with the horse they are of opposite sides.

From a rear view, it will be observed that when the hind feet are moving forward for another spring they are widely separated and pass safely outside of the fore feet, thus avoiding danger of collision. 'The very same method of safety is followed by the horse and practically all four footed mammals during the run. It may be said, however, that the apes, with their tendency toward a bipedal action, are somewhat irregular in this respect.

\section{THE TROTTING HORSE}

$\mathrm{T}$

HE importation, in 1788, of the English thoroughbred stallion, Messenger, was the first step toward the development of the fast American trotting horse, but it was not until nearly seventy-five year's later that Rysdyk's Hambletonian began to attract a great deal of attention. This sire had inherited, through both parents, much of the blood of the English horse, Messenger, and his many descendants showed a remarkable aptitude for the fast trot, a somewhat unnatural gait acquired only through adaptability, selective breeding, and special training, which has resulted in a distinct breed. The more normal trotting action is a gait of moderate speed intermediate between the walk and the run.

For the further development of the Museum's collection of Equidre it was most essential that a specimen should be obtained to show this specialized type of horse, and also to show the action of the bones in this acquired trotting gait at high speed. After waiting many year's, this opportunity was presented by the untimely death of Lee Axworthy, $1: 581 / 4$.

Through the kind interest of Mr. David M. Look, the remains of the champion trotting stallion were presented to the Museum by his owners, Messirs. Frank H. Ellis, H. K. Devereux, Coburn Haskell, and P. W. Harvey of the Pastime Stable. 


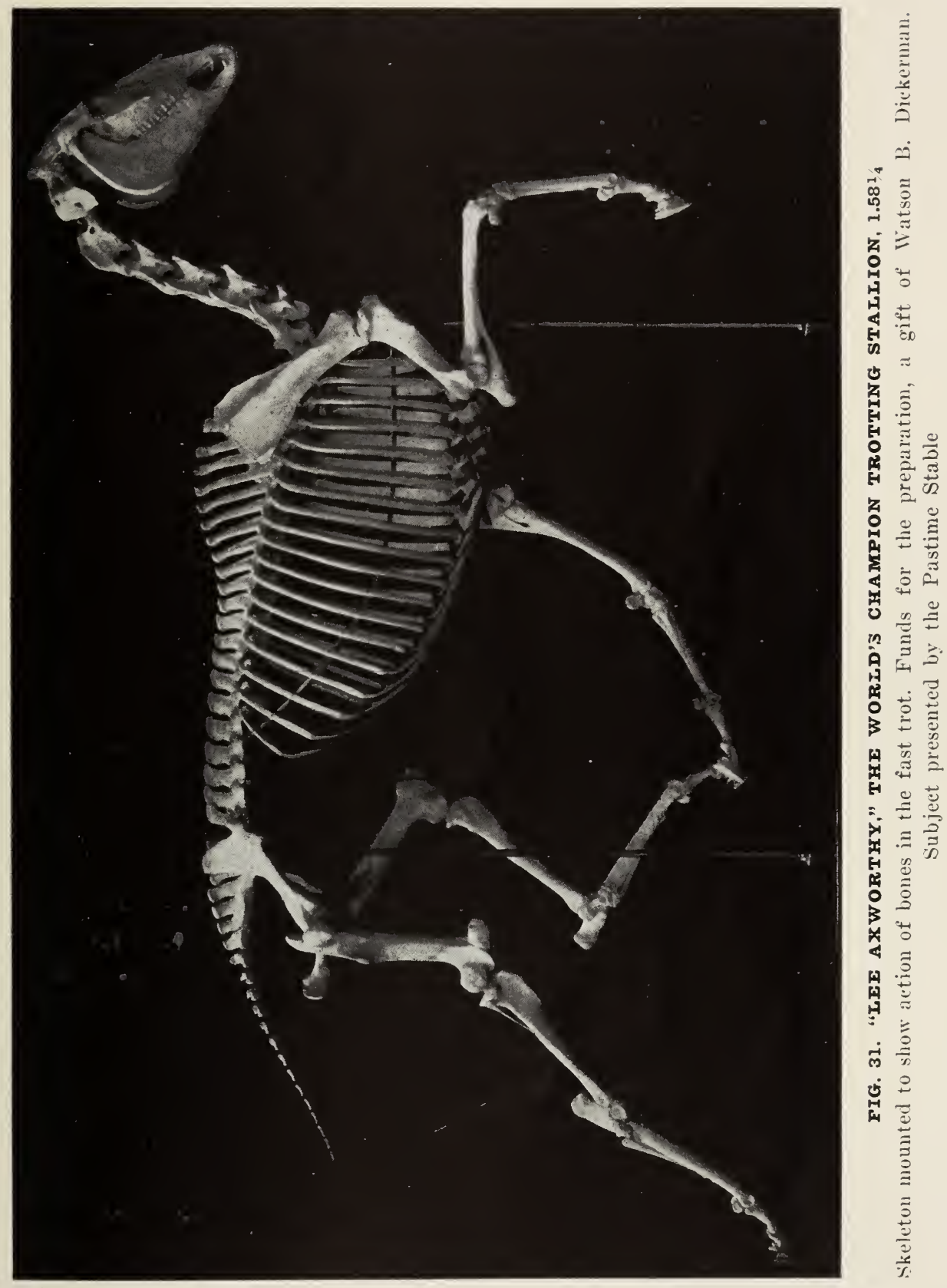


The preparation of the skeleton was made possible by the generosity of Mr. Watson B. Dickerman, who also rendered most valuable cooperation in the use of his training track for the necessary study of the trotting action.

Lee Axworthy, the first trotting stallion to make a mile record faster than 2:00 minutes, was foaled at Donerail, Kentucky, in the spring of 1911. He was sired by Guy Axworthy, $2: 08 \% \frac{1}{4}$, and his dam was Gaiety Lee, $2: 163 / 4$.

As a three year old he made a record of $2: 08$, which he reduced in 1916 as follows :

$\begin{array}{lll}\text { August } 22 & \text { North Randall, Ohio } & 2: 001 / 4 \\ \text { September } 12 & \text { Syracuse, New York } & 2: 00 \\ \text { October } 4 & \text { Lexington, Kentucky } & 1: 591 / 2 \\ \text { October } 8 & \text { Lexington, Kentucky } & 1: 581 / 4\end{array}$

The following spring he was retired to the stud at Castleton Farm, near Lexington, Kentucky, where he died suddenly on November 7, 1918.

The skeleton of Lee Axworthy (Fig. 31) has been prepared to show the extreme action in the fast trot, and is based on studies made in dissection, direct observation of living animals, and from instantaneous photographs taken on the track. The position selected is that which occurs the moment after the right hind foot has left the ground, the left fore foot having been lifted a fraction of a second earlier. The footfalls in order are as follows: the right fore foot, then the left hind foot, giving a perceptible period of contact with the ground. When these two feet are lifted there follows the period of complete suspension, after which the left fore foot and then the right hind foot will strike the ground. With some trotters this order is reversed, the hind foot striking a very minute fraction of a second earlier than the opposite fore foot. An individualism of the present subject is the high action of the fore feet.

From a rear view it will be seen that the left hind foot is moving forward with an outward curve, thus safely clearing the fore foot. Instantly the fore foot will move forward out of the way of the hind foot, which will then curve in toward the median line and strike the ground.

At the present moment the backbone is slightly curved to the right, owing to the drawing together of the left feet and the wide separation of the right feet.

\section{WILD SPECIES OF THE FAMILY EQUIDE}

\footnotetext{
$\mathrm{A}$ MONG the Equidæ still represented as wild types are a number of species of asses and zebras, none of which are so closely related to our domestic horses as the Przewalsky, the wild horse of Mongolia, already referred to on page 41 .
} 
On exhibition is a skeleton of the Kiang, Equus kiang. This species still roams freely over the plateaux of Tibet and Central Asia. Although the external appearance is ass-like, there are certain characteristics of dentition and skull formation which would relate it much more closely to the horse than is our domestic donkey, Equus asinus.

The Kiang skeleton shows the action in the slow trot which differs greatly from the acquired action of the trained trotting horse. Although great as these differences are, they are merely results of degree in speed.

There is also mounted a skeleton of the Grant Zebra, Equus granti, a native of British East Africa, and one of the Chapman Zebra, Equus chapmani, of Central South Africa.

The positions selected for the preparation of these two specimens show phases in the walking action. In these slow movements the animal is never in complete suspension, but is in contact with the ground on at least two feet, and during part of the stride, on three feet at the same time.

\section{THE TEETH OF THE HORSE}

[COLLECTION IN WALL CASE]

$\mathrm{T}$ HE dental apparatus of the horse is one of the most interesting and highly specialized organs that we find in nature. During the course of evolution through many ages, the teeth have gradually grown more and more complex, becoming constantly more perfectly adapted to the cropping and grinding of coarse, hard grasses. They are, in fact, of such great size and importance that the whole skull seems constructed chiefly for their lodgment and operation, the custody of the brain, eyes, and ears being, as it were, of secondary consideration; hence the skull must of necessity be very bulky and, in order that the weight may not be unnecessarily great, large air spaces (sinuses) are provided, aggregating between two and three times the amount of space occupied by the brain (specimens 51 and 5 , on exhibition in wall case). Indeed the skull of the horse is a beautiful design in arches and braces, resulting in a structure of the greatest possible strength and utility with a minimum of weight and material.

The ethmoids, the bony framework of the organ of smell, are also highly developed, with a complicated system of scrolls presenting an immense amount of surface to the air that is drawn into the nostrils (specimens 5, 10 and 51). 


\section{STRUCTURE OF THE TEETH}

$\mathrm{A}$ VERY simple form of tooth is that commonly found among the reptiles a mere peglikestructure composed of dentine with a very much harder covering of enamel on the crown, and a nerve canal in the center. We have selected three incisor teeth of less simple form (Fig. 32) to show examples of different degrees of specialization. A, the tooth of a young cow, is of comparatively simple form, being somewhat flattened and having a clearly defincd line or neck between the crown and the root. The crown is composed of dentine completely covered with enamel, on the surface of which is deposited a thin and incomplete layer of a third element known as cement. The root is of dentine with a pulp or nerve eavity rumning through it and extending into the crown. The neck. or base of the crown, as in most simple teeth, coincides with the line of the gum. In the horse the composition of the teeth is the same except that the cement, which begins to be deposited on the surface some time before the eruption of the young tooth, covers the enamel more completely and is very much thicker. In design it is more complicated. Instead of the plain upper border, as in Fig. 32A, there is a very decp indentation or folding in of the enamel, somewhat like the inverted finger of a glove, forming an enamel lined cup or cul-clesac, running far down into the tooth (Figs. 32C and $D$ ), becoming more or less completely filled, particularly toward the bottom, with a deposit of cement. It is usually observed that highly specialized organs are more primitive in the young individual than in the adult. This is very noticeable in Fig. 32B, which represents the deciduous or milk incisor of a colt about four days olel. This tooth has just eut through the gum, and does not as yet show any wear from use. The enamel (up is very shallow as compared with that of the permanent tooth $(C$ and $D)$. It also shows a clearly defined line at the base of the crown which, when the tooth is fully grown, will coincide with the line of the gum as in the teeth of the cow and other simple teeth. The root, not being fully grown, does not taper to a point as it will later, but presents a wide opening at the base, which will be gradually reduced to a small foramen for the passage of the nerve (Fig. 33h). At the early stage shown in Fig. 32B, the pulp cavity is very large, so that the young tooth is a hollow shell. Figure $32 C$ shows the permanent ineisor of a colt two rears old, which will erupt and replace its deciduous predecessor at about three and a half years. The cul-de-sac is very deep, rumning down more than half the length of the crown. The root has not yet begun to develop. There is already considerable cement in the cul-de-sac, and a very slight deposit beginning on the external surface about the upper end of the crown. The pulp cavity is, proportionately, much smaller than in $B$. A series of vertical sections of incisor teeth, exhibited in the wall case, will explain the structure more clearly. 

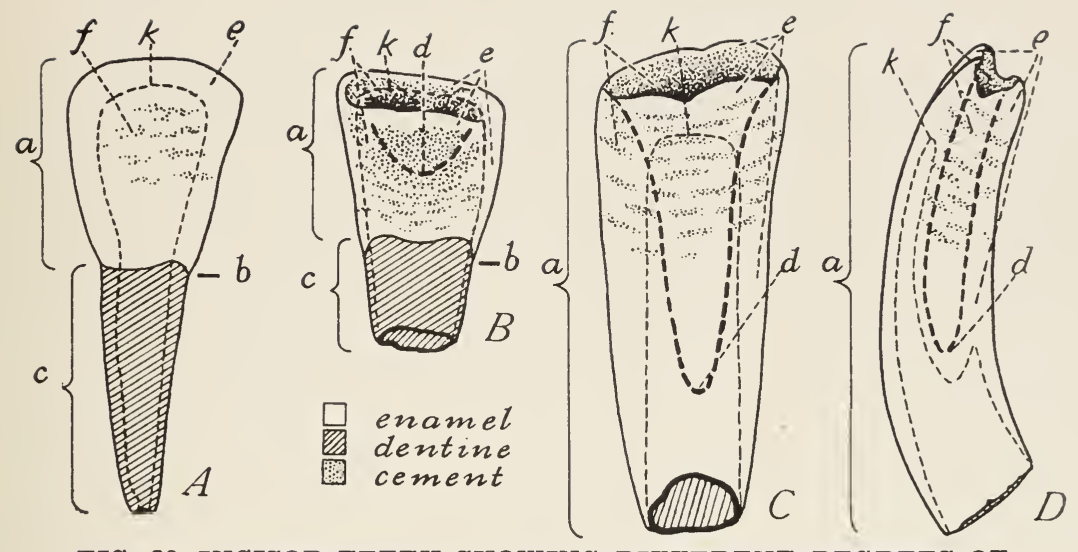

FIG. 32. INCISOR TEETH SHOWING DIFFERENT DEGREES OF SPECIALIZATION

\section{Natural size}

A. Permanent tooth of young cow. $a$, crown ; $b$, base of crown; $c$, root; $e$, enamel ; $f$, cement deposited on enamel; $k$, a pex of pulp or nerve cavity

B. Deciduous tooth of colt 4 days old. $a$, crown; $b$, base of crown ; $c$, incomplete root; $d$, bottom of cul-de-sac ; $e$, enamel; $f$, cement; $k$, a pex of pulp or nerve cavity

C. Permanent tooth of colt 2 years old. $a$, crown; $d$, bottom of cul-de-sac ; $e$, enamel ; $f$, ce-

. ment; $k$, apex of pulp or nerve cavity

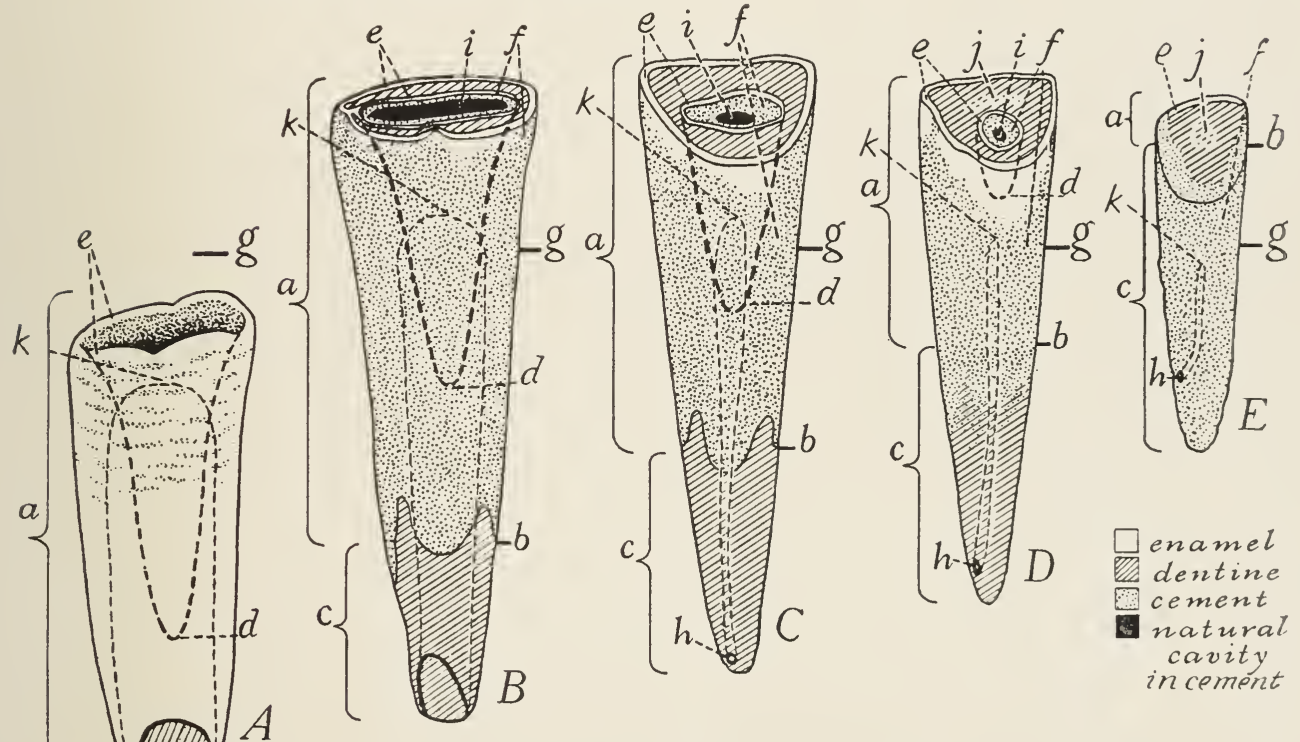

FIG. 33. INCISOR TEETH OF THE PERIANENT SET SHOWING WEAR AND MOVEIMENT

Posterior view. Natural size.

A. Unerupted tooth of a colt 2 years old. $a$, crown; $d$, bottom of cul-de-sac ; $e$, folded edge of

enamel, unworn; $g$, gum line; $k$, apex of pulp or nerve cavity

B. Tooth of horse 4 years old. $b$, base of crown; $c$, incompleted root; $e$, worn edges of ena-

C. Tooth of horse 12 years old. $c$, root fully grown; $h$, nerve foramen

D. Tooth of horse 17 years old. $j$ " "dental star"

E. Tooth of horse 33 years old. $f$, cement, external only 


\section{WEAR AND COMPENSATING MOVEMENT OF THE INCISORS}

W

HA' $\mathrm{T}$ ' is frequently spoken of as "growth" in the horse's teeth is not growth, but rather movement. It is true that growth does continue in some few of the teeth until the horse is ten or twelve years old, but only in the completion and closing of the roots, as noted above, the erowns being all fully developed, including grinders as well as incisors, at about five and one-half years. Long before the tooth has commenced its service, it begins to move from the alveolar eavity, or dental grouve, which fills with new bone at the base. This movement counteracts the rather rapid wear of the cutting or grinding surface, so that in extreme old age some of the teeth may be worn down to the very points of the roots. One of their most remarkable specializations is the extremely long crown which instead of being entirely above the gum line, as with the more simple teeth, human for instance, extends far down into the alveolar cavity, $35 / 8$ inches in the large premolars, as a reserve of grinding material. Figure 33 shows a series of incisors to explain the manner in which the tooth is worn as it proceeds from the alveolar cavity, the wearing surface altering in contour as it progresses along the crown of the tooth which constantly changes in shape toward the root.

$A$ is the permanent tooth of a colt two years old, before it has replaced its deciduous predecessor or has received any wear, so that the external enamel is continuous with that of the cul-de-sac or internal enamel. The cement now lines the eul-de-sac and is beginning to be deposited on the external enamel. As yet the tooth is without root, but has a wide-open pulp cavity which extends far up into the tooth, passing between the eul-de-sac and the anterior wall of the tooth. This is more clearly shown in the side view (Fig. 32D).

Fig. $33 B$ is the tooth of a horse about four years old. It has recently replaced its deciduous predecessor, having been in use only about six months. The folded edge of enamel is worn through, exposing the dentine beneath, and separating the enamel of the eul-de-sac from that of the exterior, with the exception of a very slight connection at the lefthand border. Internal as well as external enamel is covered with cement except on the wearing surface. The base of the crown is not clearly defined but ean readily be located as it coincides with the lower border of enamel. It will be seen that this point, instead of being at the surface of the gum as in more primitive teeth, is planted about an inch and onefourth deep, $g$ indicating the gum line. 
$C$, the tooth of a horse about twelve years old, shows a roughly triangular wearing surface, having been worn down a distance of perhaps three-eighths or one-half inch. The cul-de-sac is greatly reduced in surface diameter, as well as in depth. The root is fully developed and shows a somewhat shorter and very much narrower nerve cavity, with the nerve foramen $(h)$ at the point. With the advance of age the wearing surface of the tooth, molar as well as incisor, must necessarily approach the nerve, which would subject it to exposure. This is provided for by the recession of the nerve and a new growth of dentine, reducing the pulp or nerve cavity and sometimes in extreme old age completely filling it. ${ }^{1}$ As the tooth wears down this new dentine can be detected in the incisor by a slightly lighter sliade in color, and is known among horsemen as the "dental star." It is indicated in $D$ and $E$.

In $D$, showing the tooth of a horse about seventeen years old, the wearing surface is more nearly triangular. The cul-de-sac is almost worn away; the base of the crown is approaching the gum line. Not only is the cement thickly covering the crown, as in the younger teeth, but it is encroaching upon the root as well so that the base line of the crown is obliterated, but can readily be located by sectioning. On the more exposed ridges, however, particularly the anterior surface not shown in the sketch, the cement has been worn through in places by friction of the tongue and lips.

$E$ shows the condition in extreme old age, this specimen being the tooth of a horse thirty-three years old. The cul-de-sac has long since been worn away and the only enamel remaining is a very narrow strip on the anterior border, the base of the crown having passed beyond the gum line. The wearing surface lias become elliptical, and the "dental star" has changed from a transverse stripe to a rounded spot. The nerve cavity is reduced to a narrow canal. The deposit of cement lias increased, in some places, to almost an eighth of an inch in thickness particularly at the point of the root, which has extended far beyond the nerve foramen $(h)$ at the side. This thickening and extension of the root by cement would seem to be a provision to prolong the tooth's service to the very last.

It is by the examination of these indications that horsemen ascertain the age, although it is impossible to judge accurately in the more advanced stages. Especial attention is given to the size and shape, presence or absence of the cul-de-sac, known among horsemen as the "mark." It should be explained, however, that the lower incisors which are more easily examined in the living horse, being somewhat smaller

${ }^{1}$ See specimen No. 132 under "Longitudinal Sections of Grinding and Incisor Teeth," on exhibition in wall case. 
and having a shallower cul-cle-sac than the uppers just describerl, will acquire a certain appearance of wear at an earlier age. For instance, if $C$ and $D$ were lower teeth they would have a similar appearance at the ages of eight and twelve years. Considering the incisor set as a whole, it shows other marked changes with the atvance of age. 'T'o render effective service the teeth must be in close contact; therefore, as each tooth is reduced in diameter it moves slightly toward the median line, reducing the total transverse measmement of the set. The meeting angle of upper and lower teeth becomes much more acute in old age. An exhibit labeled "Series of IIorse Muzzles" in the wall case shows the general appearance of the incisor teeth at various ages.

The eanine tooth is of comparatively simple strueture and has no apparent function at the present time, but may have been of service as a weapon at a very early stage of evolution. It receives almost no wear, has little or none of the compensating movement of the incisors and is, in fact, of no very great interest. 'This tooth is very rarely found in the female except in an abortive form.

\section{DESIGNATION OF THE TEETH}

$\mathrm{T}$ HE deciduous or milk teeth, which are shed and replaced by permanent ones, are divided into three classes: in front, the decituous incisors, back of these, the rery small deciduous canines, and still farther baek, the deciduous molars.

In the permanent set the incisor's and canines have replaced their deciduous predecessors, and the deciduous molars have been replaced by the premolars. Still back of the premolars comes a fourth class, the permanent or true molars, which have no deciduous predecessors.

In works on comparative anatomy and zoology the teeth are expressed by initial letters and numerals in fractional form; the numerator denotes the number of upper tecth, and the denominator the number of lower teeth of each class, rumning back from the median line in front, and considering only one side of the skull. For instance the typical mammalian milk dentition is as follows, all being deciduous teeth; incisors three, canine one, molars four, which would be expressed $d . i . \frac{3}{3}$, d.c. $\frac{1}{1}$, d.m. $\frac{4}{4}$. The permanent dentition would be $i . \frac{3}{3}, c . \frac{1}{1}, p . m . \frac{4}{4}$. and $m \cdot \frac{3}{3}$-forty-four teeth in all. The human subject liaving only thirty-two permanent teeth, would be expressed $i$. $\frac{2}{2}, c \cdot \frac{1}{1}, p . m . \frac{2}{2}$, and $m \cdot \frac{3}{3}$.

The teeth are numbered from the median line, hence when indicating a certain tooth $i$. ${ }_{3}$ would be read, lower incisor three; p.m. 4 , upper premolar four ; lower deciduous canine is expressed d.c. - Figure 34 shows the designation of deciduous and permanent teeth of the horse. $A$ is the 

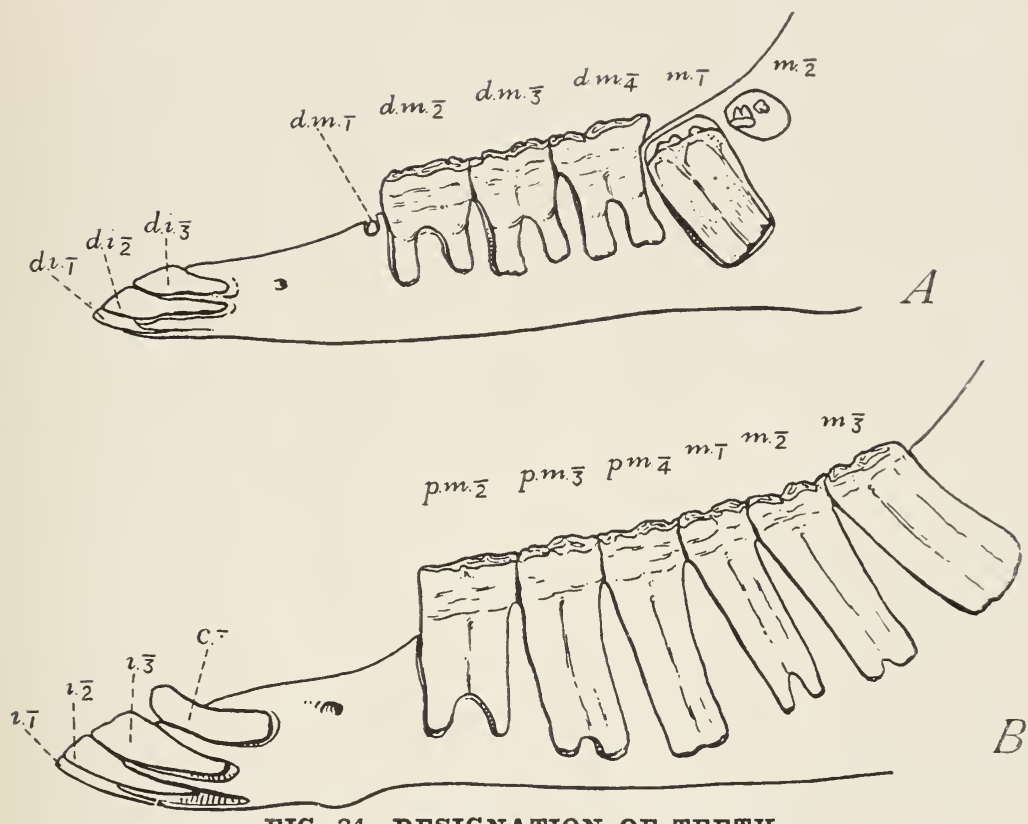

FIG. 34. DESIGNATION OF TEETH

A. Lower jaw of colt 9 months and 12 days old, marked to show designation of deciduous teeth. Specimen No. 36

B. Lower jaw of horse 5 years old, marked to show designation of permanent teeth Specimen No. 26

lower jaw of a colt nine months and twelve days old, in which the deciduous dentition is all in use, and though the eruption of the molars has not yet begun, the development of one at least is well under way. In $B$, a horse about five years old, the permanent teeth are all in place. It must be borne in mind that when a subject has a reduced dentition the teeth are numbered not necessarily as they appear in the jaw, but aceording to what is believed to be their true relation in the typical dentition, having forty-four teeth. For instance, in the human subject where there are but two premolars, known among dentists as bicuspids, the first one in the lower jaw would be expressed $p \cdot m . \overline{3}$. The second would be $p . m$. $\bar{q}$, assuming that p.m. $\bar{I}$ and $p . m$. $\overline{2}$ are the missing teeth. The teeth of specimens on exhibition, Nos. 10 and 36, are labeled in the manner described.

\section{THE "WOLF" TOOTH OF THE HORSE}

TN the horse we may say that p.m. $\frac{1}{1}$ (Fig. 39B) is now in the last stage of elimination. Just in front of the upper premolars there is frequently found a very small abortive tooth commonly known as the "wolf" tooth. It does also oceur in the lower jaw but is very rare. It is absolutely non-functional, and is in fact detrimental, as it sometime. gives rise to more or less irritation. So that in the horse the first func- 
tional premolar is p.m. $\frac{2}{2}$. The "wolf" tooth, though interesting, is rather difficult to study owing to its irregularity. When speaking of the permanent teeth it is generally designated as $p . m .1-$, which would be correct if it really belonged to the permanent set; this, however, I am inclined to doubt, although it is frequently found long after the shedding period is over. Nevertheless, it seems highly probable that it is a deciduous tooth which, having no successor, it not shed. In this case it would seem that the permanent tooth had been eliminated earlier in the course of evolution than the deciduous one. But until we have more conclusive evidence on this point probably it will be as well to include the "wolf" tooth among the teeth with which we find it. In figure $34 A$ there is shown the unusual occurrence of the "wolf" tooth in the lower jaw. In looking over the fossil ancestors we find that this tooth began to show signs of elimination in the late Oligocene Period, which is estimated to be about nineteen or twenty million years ago. At this rate, we may reasonably hope for some few social reforms before the horse is entirely rid of this rather undesirable appendage.

\section{PREMOLARS AND MOLARS OF THE HORSE}

W

HEN we compare the molar tooth with its most intricate structure, with the incisor, the latter seems perfect simplicity. Without here discussing the evolutionary history of the tooth, it is extremely interesting to consider these special adaptations, which are merely gradual modifications of a simple form brought about without any radical or sudden changes, but slowly developed in an orderly and, shall we say, orthodox manner.

The molar of the horse as we find it to-day is a wonderful structure, presenting on its grinding surface a most complicated system of sharp enamel edges almost as hard as glass, supported on one side by dentine and on the other by cement. These materials being somewhat softer than enamel wear down slightly in advance, leaving the enamel edges sufficiently exposed to give a perfect self-sharpening, grinding surface, but at the same time not projecting so far beyond the general plane as to be in danger of chipping off.

When we compare such a tooth as this with a perfectly simple one, composed of dentine and having a short, either cone-shaped or flattened crown, covered with a smooth shell of enamel, it is difficult at first sight to see any relation or similarity between them, or to realize that the highly specialized organ is simply a modification of the primitive structure. We have already shown that the incisor of the horse is a modification of the primitive tooth. Now, let us consider the more complex deciduous upper molar of a colt before there has been any wear on the 
grinding surface. 'The crown in form is somewhat like an irregular pillar, composed of dentine with two deep depressions in the top, the dentine being completely covered with enamel, and a thick deposit of cement on the surface of the enamel.

When the cement and enamel are worn through on the grinding surface we have the exposed edge of an enamel cylinder filled with dentine, reënforced with cement on the outer surface, and two enamel pockets, with the edges exposed, imbedded in the dentine. These pockets or depressions are lined on their inner surfaces, or completely filled, as the case may be, with a deposit of cement. This is a construction similar to that we have already seen in the incisor, except that we have two instead of the single cul-de-sac, and that the enamel walls of these culs-de-sac, as well as the external enamel wall are deeply crenated or folded and doubled, in some places the inner coming almost in contact with the outer enamel, thus increasing greatly the exposed enamel edges, as shown in Fig. 35A. It must be borne in mind that the horse's teeth are not fully functional until the folded edges of enamel on the grinding surface are worn through to the dentine.

Figure $35 B$ shows the grinding surface of a deciduous upper molar $(d . m$. $\stackrel{4}{)}$ ) of a colt about three months before birth. The enamel of the culs-de-sac is continuous with that of the exterior, the folded edges on the grinding surface being unworn. It is as yet entirely without cement so that we have an unobstructed view of the enamel. When the colt is six months old, however, the culs-desac will be practically filled with cement and also the deep folds of the exterior (Fig. $35 \mathrm{~A})$, the deposit of cement beginning about a month before birth.

We have seen that the permanent incisors are much more highly specialized than are the deciduous ones (Page 54). This is quite as noticeable in the grinding, or cheek,
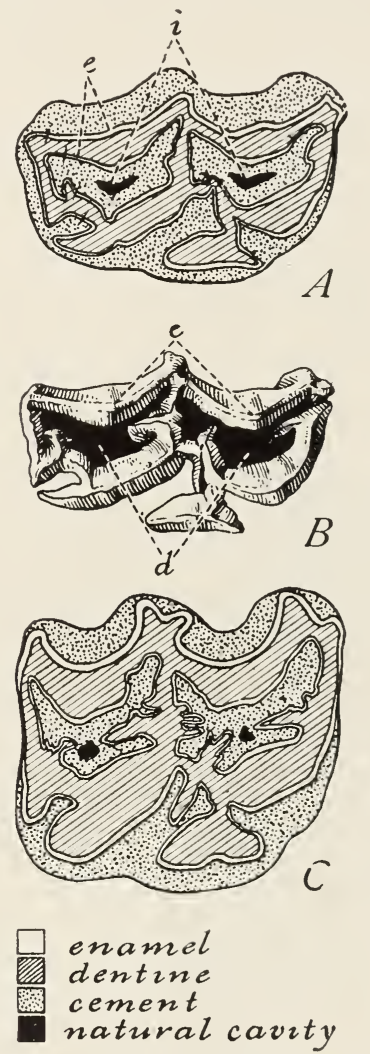

FIG. 35. WEARING SURFACE OF UPPER GRINDING TEETH.

Natural size.

A. Worn surface of deciduous molar $(d . m .4)$ of colt about 6 months old. $e$, exposed enamel edges ; $i$, natural cavity in cement

B. Unworn surface of deciduous molar $(d . m .4)$ of colt about 3 months before birth, showing enamel only. $d$, cul-de-sac to be filled later with cement; $e$, apex of folded edge of enamel

C. Premolar $(p, m . \underline{3})$ of horse 8 or 9 years old 

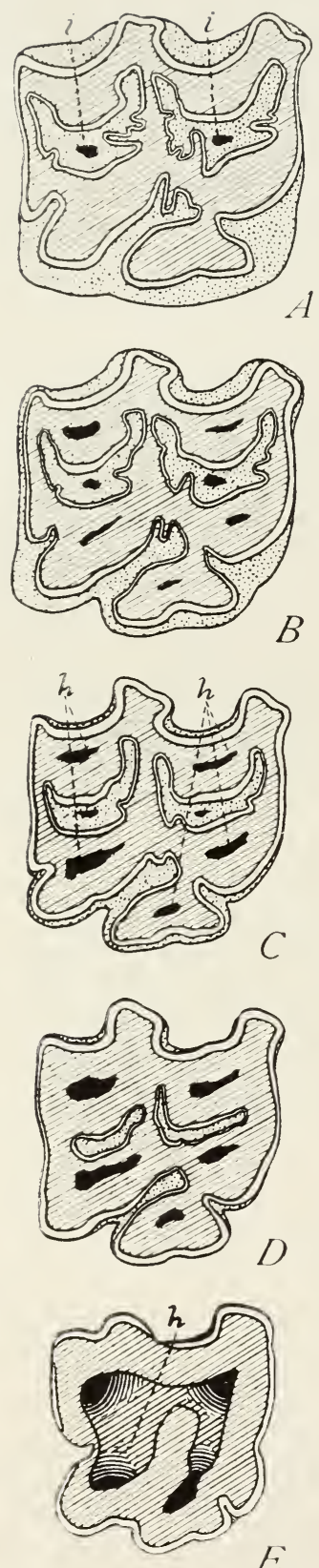

E

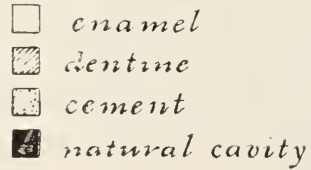

teeth. Observe the wonderful development of enamel edges in figure $35 C$ as compared with A. $C$ is a premolar of a horse eight or nine years old. A careful measurement of the exposed enamel in this tooth reveals the interesting fact that, if these edges were straightened out in a continuous line, it would be fourteen inches in length. In a tooth of this size on the simple "cylinder" plan, it is obvious we would have only about four inches of enamel, hence we can willingly concede nature's wisdom in this comparatively "moder'n improvement."

This enamel pattern, however, presents a more simple aspect as the tooth wears down toward the base of the crown, so that in old age when the grinding surface is near the root, there is less enamel, and the self-sharpening surface is much less perfect. The anteroposterior diameter of the crown is also reduced toward its base. Figure 36 shows an upper right grinder $(p . m . \underline{4})$ of a horse ten or eleven years old. The tooth is cut in five sections, and reveals on each cut surface the pattern of enamel which will be presented on the naturally worn grinding surface at various ages.

Section $A$ is a diagram of the natural grinding surface as it appeared in life, and shows a very complicated pattern of enamel, and large culs-de-sac almost completely filled with cement.

Section $C$ which is cut one and one-fourth inches farther along the crown, a point that would be reached by natural wear at about twenty-five years, shows great simplification of enamel pattern, and the culs-de-sac are much smaller than in $\boldsymbol{A}$ and $\boldsymbol{B}$. The five branches of the pulp cavity $(h)$ are open, but in life

\section{FIG. 36. UPPER GRINDER (P.M. 4) OF HORSE 10} OR 11 YEARS OID

Cut in 5 sections; showing pattern of enamel at various ages.

A. $i$, Natural cavity in cement

$C$. $h$, Branches of the pulp cavity

E. h. Pulp cavity 
would have been filled with new dentine before the natural grinding surface reached this point.

Section $E$. The lower border of enamel which marks the base of the crown where this section is cut is somewhat irregular, so that the enamel line is incomplete. This explains the three spaces which can be seen in the external enamel. The culs-le-sac are entirely eliminated and the enamel edges are reduced to a minimum. The branches of the pulp eavity are united at this point $(h)$, where the roots begin to diverge. The diameter of the tooth is also greatly reduced. This tooth,

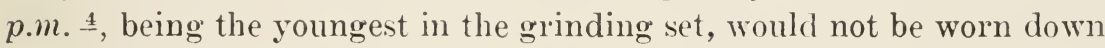
to the base of the crown until the horse reached thirty-five or more years, an age rarely attained. Sections of grincling teeth on exhibition, particularly specimen No. 95, will be of interest as illustrating strueture and wear.

The lower molars in their construction are similar to the uppers, though there are some obvious differenses, the most striking one being the absence of the culs-de-sac. Much the same result is aequired, how-

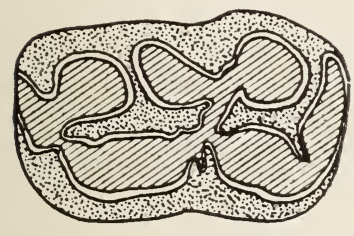

FIG. 37. LOWER PRE. MOLAR
HORSE 8 OR 9.3 Y Y OR
OLD ever, by the very deep folding in of the external enamel, which at several points almost meets toward the center (Fig. 37). The lower molars are also narrower in their transverse measurement, which would seem to shorten their period of wear. This lesser width, however, is comnteracted by a greater length of crown, so that the period of service is about equal to that of the uppers.

There are several points which sometimes lead to a little confusion in observing the wearing surface of the grinding teeth. For example, at the bottom of the deeper concrve surfaces of dentine between the enamel walls, there is a dark brown mark which is somtimes mistaken for a fourth material, but is merely a coloration of the dentine.

In the upper grinders we generally find two snall cavities (Fig. $35 A$ and $C$ ), one in each cul-de-sac, which sometimes give rise to questionings; and indeed there have been swindler's masquerading as veterinary dentists, who would gladly "fill" your horse's teeth for a reasonable consideration. These cavities, however, are perfectly normal. as already explained, their presence or absence depending simply upon the thickness of the cement.

It will be seen that where the tooth comes in close contact with its next neighbor, the cement is missing, and indeed, sometimes the continuous line of external enamel is broken (Fig. 37). This is due to a 
slight wear on the side of the tooth. There is a strong tendency to crowd toward each other, thus preventing the forcing of food material between them. The slight vibration, when in use, of each tooth in its alveolar socket affords sufficient wear to keep them perfectly fitted together, and also explains the apparent break in the external enamel wall, which we frequently see. This crowding together, as well as many other features, can best be observed from the side view as shown in a series of skulls, on exhibition, with the bone cut away in order to expose to view the full length of the teeth.

The posterior teeth, or molars, incline very considerably to the front, while the premolars lean slightly toward them (Fig. 39), so that when pressure is applied on their grinding surfaces they are forced together like stones in the arch of a building. And as the teeth wear down to a point of smaller diameter, the lower molars in extreme old age incline more toward a horizontal position, particularly $\mathrm{m}_{\overline{3}}$ (Fig. 39C).

The grinders from a lateral view present a most formidable looking dental battery. It gives some idea of their development when we find that a full set of premolars and molars, taken from a fair-sized horse of four or five years, will weigh about four pounds, the premolars being heavier and more highly developed than the molars, a fact which is quite unusual, as in the great majority of mammals the premolars are very much inferior in size and development, as was also the case in the ancestral horse. ${ }^{1}$

We see, from the lateral view as well as from the grinding surface, the more highly specialized character of the permanent teeth. Compare

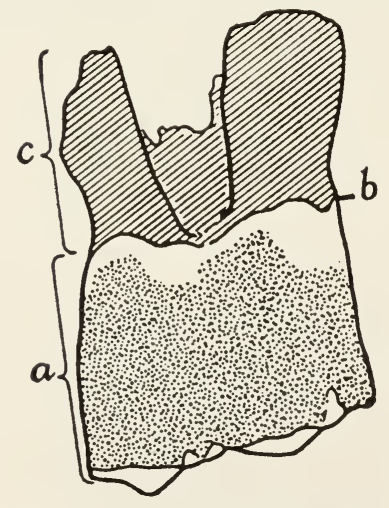

FIG. 38. DECIDUOUS MO-

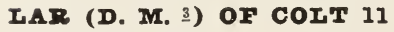
MONTFS OLD

Natural size. $a$, crown; $b$, base of crown; $c$, root

${ }^{1}$ See page 15 . the very long crowns of figure $39 \mathrm{~A}$ with the deciduous molar (Fig. 38), with its short crown, clearly defined base line, and flaring roots.

Wear and movement of premolars and molars can be studied very readily from the skulls on exhibition, three of which are shown in figure 39.

For the present we will consider only the lower teeth, which will apply in a general way to the upper as well. The calcification of the tooth begins at the grinding surface, inside the alveolar cavity. and proceeds toward the root, the tooth constantly moving upward, erupting and beginning to wear off before even the crown is complete. 

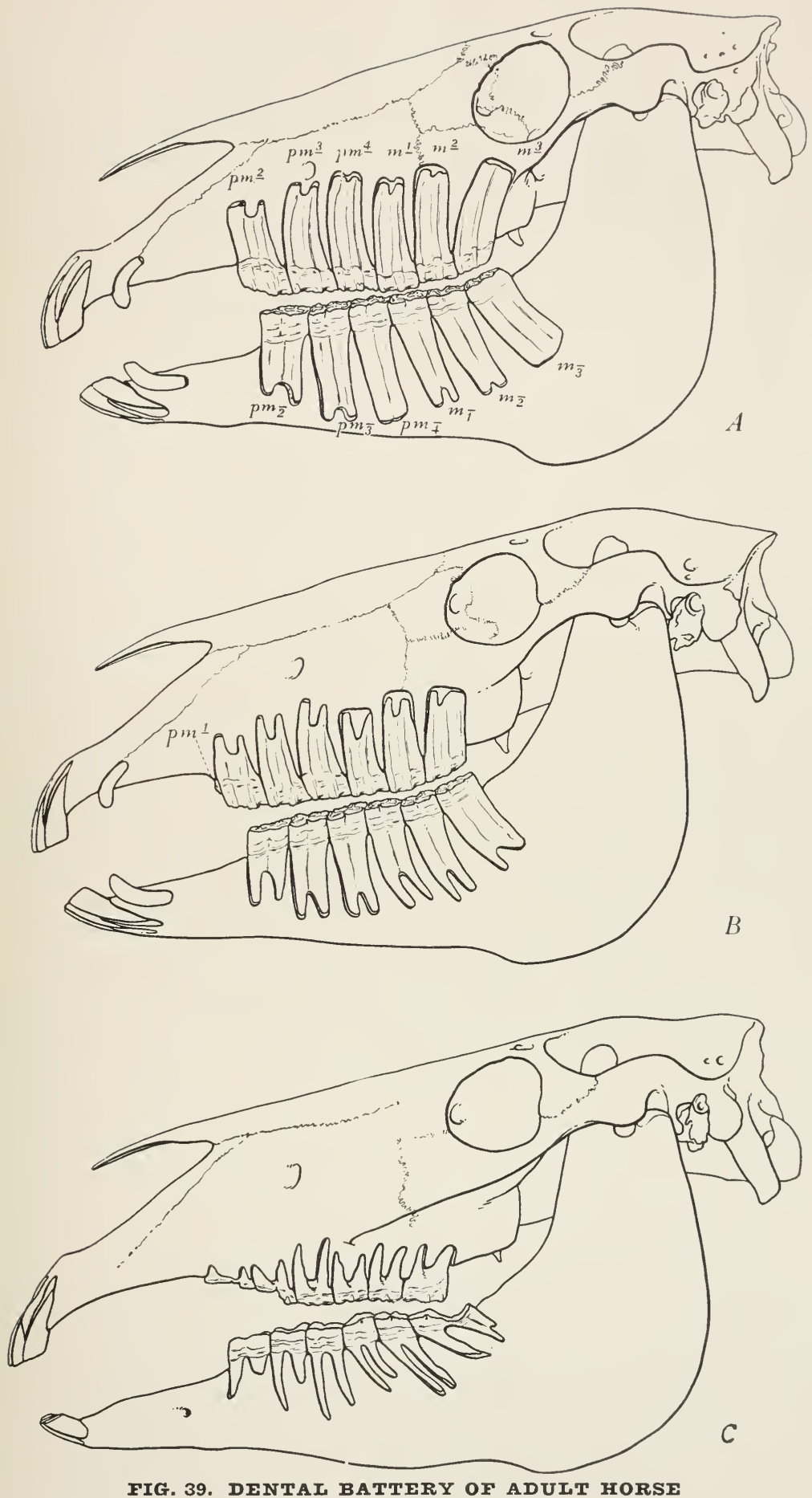

A. Skull 5 years old. Permanent teeth all in use. Specimen No. 26 . gial $p . m .1$ present in this individual. Specimen No. $22 \sigma^{\circ}$ C. Skull 39 years old. Crowns almost worn away. Lower molars incline forward. Canines absent. Specimen No. 40 ㅇ 
Figure $39 \mathrm{~A}$ shows the skull of a horse about five years old. 'The deeiduous set has been shed and the permanent teeth are all in use, though the "wolf"' tooth $\left(p . m, \frac{1}{1}\right)$ is not present in this specimen. The crown of $p . m$. $\frac{\pi}{4}$, the last tooth in the grinding set to reach the wearing line, has just completed its growth, having already lost about half an inch from wear. There now remains a length of three and a half inches to be slowly moved upward and worn away should the horse live to an extreme old age. The roots are just beginning to develop at the base of the crown. The next tooth back of this, $m$. 1 , is the first permanent tooth to appear, hence the oldest one in the mouth. 'The crown is worn down much shorter than that of $p . m .{ }_{4}$, and the roots are quite evident, though still incomplete.

In figure $39 B$, showing a specimen about eight years old, the crowus have all been perceptibly reduced by wear, and the roots are all more or less developed, those of $m$., , being almost completely grown.

The oldest skull ${ }^{1}$ in our exhibit is a specimen from a horse thirtynine years old, (Fig. 39C). Several of the crowns are worn down to the roots, while the others have but little grinding material in reserve. Some of the roots are very much elongated, while others are thickened by an extreme reenforcement of cement. The molars are very much inclined forward, particularly $m \cdot \overline{3}$, which is so worn as to almost separate the two roots. In the upper set, $p . m . \underline{2}$ is represented only by irregularly shaped lumps of cement which surround the last fragments of roots, prolonging to the utmost their very much impaired service. ${ }^{2}$

\section{ERUPTION OF THE TEETH OF THE HORSE}

$\mathrm{T}$

HE calcification of all the decidnous teeth and also of $m \cdot \frac{1}{1}$ begins before birth. When the colt is born, d. $i \cdot \frac{1}{1}$ and $d . m . \frac{2}{2}$ and $\frac{3}{3}$ are very near the surface of the gum, and generally erupt within two or three days; $d . m \cdot \frac{4}{4}$ is apt to follow during the first month ; the next tooth will be $d . i . \frac{2}{2}$, which appears between the fourth and six months; d. $i$. $\frac{3}{3}$, the last deciduous tooth to erupt, makes its appearance as late as the eighth or tenth month.

When we examine (Fig. 40A) a skull before birth at about the fifth or sixth month of fotal life, we find that thespace occupied by the deciduous molars in their alveolar cavities seems out of all proportion to the length of the skull, so that $d . m .2$ and $d . m . .^{3}$ occupy as great a proportion

${ }^{1}$ Since writing, a skull 421/2 years old has been obtained, Specimen No. 138 on exhibition.

${ }^{2}$ Specimen No. 132 in wall case shows interesting examples of reënforcement by cement in extreme old age. 

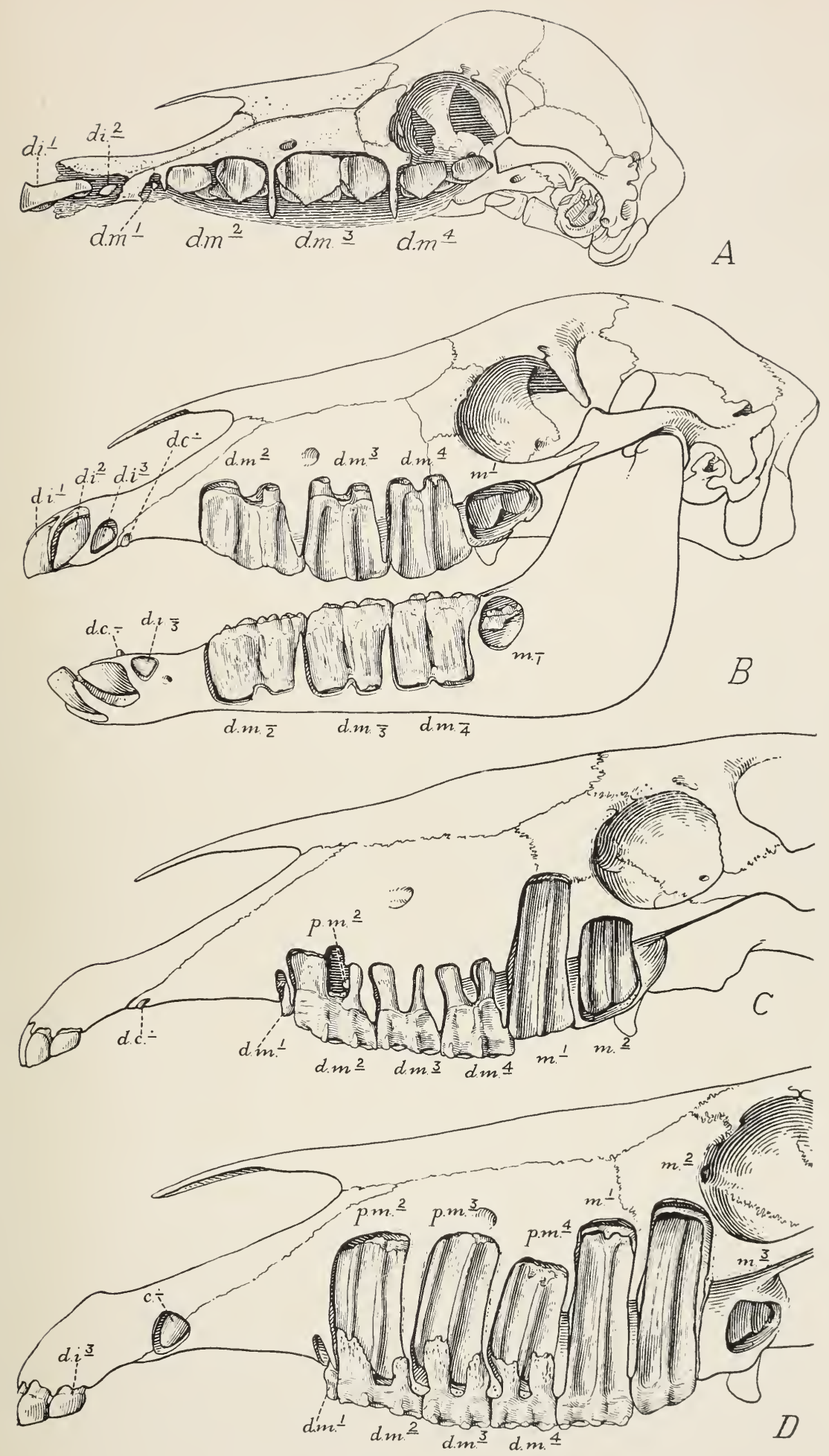

FIG. 40. DENTITION OF THE COLT

A. The 5th or 6 th month of fotal life. 1' Natural size. Specimen No. 2

B. Colt 2 days old showing deciduous teeth and early stage of $\mathrm{m}$. $\frac{1}{1}$. 1/3 Natural size. Specimen No. 35 o

C. 11 months old. Deciduous teeth somewhat worn and permanent set developing. $1 / 3$ Natural size. Specimen No. 28 .

D. 2 years old. Deciduous teeth very much worn and permanent set partly in use $1 / 3$ Natural size. Specimen No. 49 त 
of the length of the skull as will finally ateommodate the whole grinding set of the adult horse. Consequently $d . m . \pm$ is rrowded far back, begimning its development in the atveolar cavity direetly betow the eye socket, as shown in figure $40 \mathrm{~A}$. This discrepancy, however, is nicely adjusted. As fast as the increasing size of the skull will permit, the teeth are crowded forward with a horizontal movement, making room at the back for the development of the molars, each one in turn resigning its birth-place below the eye, and moving forward to make room for the next one to fall in line, the operation being about the same in the lower set as in the upper teeth. It will also be seen that $d . i$. 1 projects beyond the present border of the muzzle. At this early stage the bone is incomplete but will surround the young tooth a little before birth. In the mean time, the tooth is protected by soft tissue.

The incisors also encroach upon the region of the very small $d_{0} c . \div$ particularly $d . i . \overline{3}$, which begins its development well back of the $d . c .-$ (Fig. 40B) a colt 2 days old. With the elongation of the jaw $d . i \cdot \overline{3}$ passes forward and assumes its final position in front of $d . c .-$.

At eleven months (Fig. $40 \mathrm{C}$ ) the deciduous teeth are all in use and most of them considerably worn. $m .1$, which is due to erupt within about a month, has increased wonderfully in length and has moved forward, giving up the place under the eye to $m . \stackrel{2}{2}$, which has already attained considerable size, and has advanced somewhat in its forward movement. Between the roots of $d . m . \stackrel{2}{ }$, which are flattened and widely spread apart, thus making room for the new tooth, the calcification of p. $m . \stackrel{2}{2}$ is just beginning. $i, \frac{1}{2}$ is developing, and ean be seen in specimen No. $38^{1}$ far back in the alveolar eavity under the root of $d . i$. 1 , but is not visible in the figure.

In figure $40 \mathrm{D}$, a colt of two years, calcification has begun in all the permanent teeth except $i$. $\underline{3}$. The crowns of the deciduous molars are nearly worn away, while the roots are being absorbed by the growth of the premolars which have now attained a considerable size. $m .1$, the first permanent tooth to erupt, has been in wearing about a year and is just beginning to develop roots. $m .2$ has eut through the gum and is very slightly worn. The upper end of this tooth seems to be shooting upward in dangerous proximity to the eye socket but, fortunately for the young colt's outlook upon life, will move forward just in time to escape a collision. The alveolar cavity below the eye is now lodging its last young tenant, $m . \underline{3}$, which will erupt at about four years and by the time it is full grown will be nearly two inches anterior to its present position. However, in considering changes in a growing skull, it is 
difficult or impossible to locate any fixed point, as there is so much readjustment throughout life, particularly during the rapidly growing period of immaturity. But, if we arbitrarily make our measurements from the center of the orbit, we find that $p . m .4$, in a mature skull of average size, is seven inches anterior to the point directly below the eye socket which gave rise to its deciduous predecessor, d. m. $\stackrel{4}{2}$ (example Fig. 39B).

\section{SHEDDING THE TEETH}

$\mathrm{B}$ EFORE the deciduous molars are shed the crowns are almost entirely worn away on the grinding surface, while the roots are al)sorbed by the new teetl at the base, so that there is only a small fragment of tooth really lost. The time of shedding may vary a numb. l' of months: At approximately three years $d . m . \frac{2}{2}$ and $\frac{3}{3}$ are shed, exposing the grinding surfaces of $p \cdot m \cdot \frac{2}{2}$ and $\frac{3}{3} \cdot m \cdot \frac{1}{1}$ and $\frac{2}{2}$ are in use and somewhat worn. At about three and one-half years $d . i \cdot \frac{1}{1}$ will be shed. At four the shedding of $d . m \cdot \frac{4}{4}$ follows very closely after, or sometimes during the eruption of $m$. $\frac{3}{3}$. A little later $d . i$. $\frac{2}{2}$ are shed. At about five or a little before the canines will erupt and $d . i \cdot \frac{3}{3}$ are shed, and the permanent dentition is all in use. There are a number of specimens on exhibition in the wall case, not figured in this description, which it would be well to consult in connection with the shedding of teeth. 


\section{PRINCIPAL LITERATURE ON THE EQLIDE}

\section{Fossil and Modernn}

1826. Mitcheld, S. L. Catal. Org. Rem., New York, pp. 7, 8, (First record of fossil horse in America)

1841. Owen, Richard. On Hyracotherium leporimum. 'T'rans. Geol. Soc. (2), vol. vi, pp. 203-208. (Earliest record of the fourtoed horse, not then recognized as ancestral to the horse family)

1860. Hensel, R. Ueber Hipparion mediteraneum. Abhandlung. Akarl. Wiss., Berlin. (Description of the three-toed horse of southern Europe, Pliocene epoch)

1863. Diunss, E. The Horse of the Sahara. London: Allen

1863. Rutineyer, L. Beiträge zur Kemntniss der fossilen Pferde. Verhand. der naturforsch. Gesellsch. Basel, vol. iii, pp. 558-696. (Extinct horses of Europe, chiefly Quaternary)

1869. Lempy, Josepil. Extinct Mammalian Fauna of Dakota and Nebraska. Journ. Acad. Nat. Sci. Phila, vol. vii. (Numerou. American species of three-toet horses described in this volume)

1873. Kowalevsky, IV. Sur l'Anchitherium aurelianense ef sur l'I istoire Paléontologique des Chevaux. Mem. Acad. Imp. Sci. St. Petersbourg. (7), vol. xx, pp. 1-73. (First attemp) at reconstructing the ancestry of the horse from fossil specimens)

1874. Marsir, O. C. Notice of New Equine Mammals from the 'Tertiary Formations. Am. Journ. of Sci. (3), vol. vii, pp. 247 258. (First reconstruetion of the ancestry of the horse from American fossils)

1875. Burmeister, H. Los Caballos Fosiles de la Pampa Argentina. Published for the Provincial Government of Buenos Aires Exhibit at the Centennial Exhibition, Philadelphia, 1876. (Description and illustration of II ippidium and other extinct horses of South America)

1879. Mrarsir, O. C. Polydactyle Horses, Recent and Extinct. Am. Journ. Sci. (3), vol. xrii, pp. 499-505. (American ancestry of the horse, with diagrams showing the evolutionary stages)

1885. Cope, E. D. "Myracotherium" (Eohippus), in "Tertiary Vertebrata," Report U. S. Geol. Sur. Terrs., vol. iii, book 1. pp. 624-652, pll. xlixa, xlixb, xlixc. (Description and figmres of the skeleton of the four-toed horse) 
1887-90. Pavlow, Marie. Etudes sur l'Histoire Paléontologique des Ongulés. Bull. Soc. Imp. Natur., Moscow

1891. Scotт, IV. B. Osteology of Mesohippus. Journ. Morphology, vol. v, pp. 3-73. (Description and figures of the skeleton of the three-toed horse of the American Oligocene)

1891. Flower, W. H. The Horse. London. Kegan Paul, 'Trüibner' 1896. Wortuan, J. L. Species of Hyracotherium, ete. Bull. A. M. N. II., vol. viii, pp. 81-110. (Revision of the species of fourtoed horses from the Lower Eocene of North America)

1900. Lucds, F. A. The Ancestry of the Horse. MeClure's, vol. 15, pp. 511-517, October. (Popular account with diagrams, ete.)

1901. Gidetey, J. W. Tooth Characters and Revision of the North American Species of the Genus Equus. Bull. A. M. N. H., rol. xiv, pp. 91-142. (Revision of the prehistoric wild horses of the United States)

1903. Mlтthew, W. D. Evolution of the Horse. Guide Leaflet, No. 9, Am. Mus. Journ., vol, iii, No. 1 (Jan.). Second edition. 1905. (Popular guide to fossil horse specimens in American Museum)

1904. Ewart, J. C. The Multiple Origin of Horses and Ponies. Washington: Smithsonian Report [1905] pp. 437-455

1904. Hayes, M. II. Points on the IIorse. New York: Scribner's

1904. Osborn, H. F'. New Oligocene Horses. Bull. A. M. N. H., rol. $\mathrm{xx}, \mathrm{pp} .167-179$. (Species of three-toed horses from the American Oligocene)

1904. Osborn. H. F. The Evolution of the Horse in America. Century Magazine, vol. lxix, pp. 1-17. Norember. (Popular account of the ancestry of the horse and of the origin of the several modern breeds)

1905. Clarke, H. W. Horses' Teeth. (4th ed.). New York: Jenkin.

1905. Osborn, H. F. Origin and ITistory of the Horse. Address before the New York Farmers, Metropolitan Club, Dec. 19. (Pop)ular account of the origin of the modern breeds of horses and of the horse family in general)

1905. Speed, John Gilmer. The Horse in America. New York: IreClure

1906. Borden, Spencer. The Arab Horse. New York: Doubleday, Page \& Co.

1907. Lulu, R. S. The Evolution of the Horse Family. Am. Journ. Sci. (4). vol. xxiii, pp. 161-182. (Popular guide to fossil horse specimens in Yale Museum) 
1907. Gidetey, J. W. Revision of the Miocene and Pliocene Equidx of North America. Bull. A. M. N. II., vol. xxiii, pl. 865-934. (Revision of species of later three-toed horses, with observations on the phylogeny)

1908. Granger, Walter. A Revision of the American Eocene Horses. Bull. A. M. N. II., vol. xxiv, pp. 211-264. (Revision of species of tour-toed horses)

1909. Davenport, Homer. My Quest of the Arab Horse. New York: Dodge

1910. Sisson, Septinus. Text-Book of Veterinary Anatomy. Philadelphia : Saunders

1912. Liautard, A. F. A. How to Tell the Age of the Domestic Animals. New York: Jenkins

1912. Lydekker, R. The Horse and its Relatives. New York: Macmillan

1918. Osborn, II. F. Equida of the Oligocene, Miocene and Pliocene of North America, Iconographic Type Revision. Mem. Am. Mus. Nat. Hist., N.S., vol. ii, pp. 1-217, Pls. i-liv

1926. Loonis, Frederic B. The Evolution of the Horse. Boston: Marshall Jones Co.

1928. Matтhew, W. D. Outline and General Principles of the History of Life. University of California Syllabus Series No. 213. Chap. xx. The Evolution of the Horse

1929. Brown, W. R. The Horse of the Desert. New York: The Derrydale Press.

1929. Encyclopaedia Britannica. Fourteenth Edition. Animal Breeding. London. New York 


\section{INDEX}

Page numbers of illustrations are set in heary face type

Alaptation to environment, 30,32

Age determination by teeth, 56-57

Anshitherium, 17

Arabian horse, $13,40,44-45,47$

Ass, 11, 22-53; African wild, 13,32

Brown, Barnum, 20

"Bverley Turk," 45

Canines 5., 59, 6.5, 67, 69

Cook, H. J., 22

Cope, E. D., 16

Cuvier, Baron, 17

Darley Arabian, 4.5

Dental Battery of Adult Horse, 65

"Dental star," 55, 57

Desert type, 13

Devereux, H. K., 50

Diadiaphorus, 33, 34

Dickerman, Watson B., 51, 52

Domestic horse, Origin of, 39

Draft horse, $38,39,40,41-43,42,47$

Ellis, Frank H., 50

Eolippus, 10, 11, 15-16, 26, 29, 31; venticolus, 18

Epihippus, 16, 29

Equida, Wild Species of the Family, 52$5: 3$

Equus, 10, 11, 12, 13, 22-23, 31; asinus, 9, 14, 53; burchelli, 9; caballus, 29; chapmani, 53 ; complicatus, 29; granti, 53 ; grevyi, 9 ; hemionus, 9 ; kiang, 53; libycus, 39; przewalskii, 9, 13, 32, 41, 52) scotti, 12, 23, 24; stenonis, 29; zebra, 9

Equus Beds, 13

Ethmoids, 53

Evolution, Cause of, 32 ; Parallel, 33-44; natural, 39

Evolution of the Horse, 8; 14, 35, 36-37; of fore foot, 10; of fore leg, 27; of hind foot, 11, 31; of hind leg, 28

Ewart, J. C., 39, 43

Foot, Evolution of, 10, 11

Foot, structure of, 41

Forest type, 13

Fossil horses, 12-13

Four-toed horses, 14-17

"Gaiety Lee," 52
Geological range of ancestors of horse, 26

Gidley, J. W., 12, 2:3

Godolphin Arabian, 47

Granger, Walter, 16

Grinders, 56, 57, 61, 62, 6:3, 64

"Guy Axworthy," 52

Harvey, P. IV., j0

IIaskell, Coburn, 50

Hipparion, 21, 29, 31; whitneyi, 19, 21,22

Hippialium, 1:2, 23, 25

Huntington, Randolph, 40, t5

Huxley, T. H., 17

Hypolippus, 17

Hyracotherium, 14, 15, 28

Incisors, 5 $4-61,55,59,6 \mathrm{~s}$

Keene, James R., 46, 47

"Kismet," 4 j

"Lee Axworthy," 50-52, 51

Leg, Evolution of, 27, 28

Libyan horse, 44-45, 47

Litopterna, 33

Look, David M., 50

Marsh, O. C., 14, 22

Matthew, W. D., 2:3

Meaning of Change in Feet and Teeth, $27-31$

"Melton," 47

Merychippus, 10, 11, 20, 21, 27, 28, 29,31

Mesolippus, 10, 11, 17, 27, 28, 31; bairdi, 18, 29; montanensis, 29

"Messenger," 50

Miohippus, 17, 29, 31; intermetius, 17

Molars, 9, 4:3, 57-69, 59, 65, 67

"Nimr," 40, 45

Norseman's horse, $39,41,44$

One-toed horses, 202-2:?

"Optime," 47

Orohippus, 16, 29

Osborm, H. F., 2, 1:3, 20, 21, 39, 45

Owen, Richard, 14

Palaotherium, 17

Parahipus, 20, 29

Plagiolophus, 17

Plateau type, 1:3

Plesippus simplicidens, ,2:-2:3 
Pliolippus, 21-22, 2:3

Prehistoric man, $13,39,41$

Premolars, 58-69, 59, 61, 62, 63, 65, 67

Protohippus, 21-2.2

I'seudlo-liorses, 33, 34

Quagga, 1:3

Rave horse, $39,45-45,46$

Ridgeway, William, 39, 44

liussian wolfhound, 49; compared with race horse $48-50$

Rrsilyk's "Hambletonian," 50

Shetland pony, 38, 39, 43-4t; compared with draft horse, 38, 43

simpson, G. G., 23

Skeleton of horse and of man, 2,41

skull, 53, 5s, 64-69, 65, 67

steppe type, 13

"Sysonby," 46, 47-48

Teeth of colt, $55,59,61,64,66-69,67$

Teeth of horse, 9, 53-69, 65; designation,
5., 59; eruption of, 66-69, 67; evolution of, 29; pattern of enamel, 62; shedding, 69 ; specialization, 55 ; strueture, 5t; wearing of, 55, 56-5s, $60-$ bif, 61, 62, 65, 67

Teetl of Equus, 23; of Eohippus, 15; of Epihippus, 16; of Hipparion, 21; of Merychippus, 20, 21; of Mesohippus, 17 ; of Orohipuss, 16 ; of Parahippus, 20

Thoatherium, 34

Three-toed horses, 17-22

Touchstone, S. F., 47

Trotting horse, 50-52, 51

Troxell, E. R., 2.

Wells, H. F., 21

Whitney, William C., 2, 38, 43

"Wolf" tooth, 59-60, 65, 66

Wortman, J. L., 16

Zebra, 11, 13, 32, 52-53 




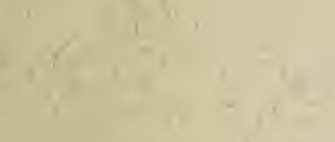

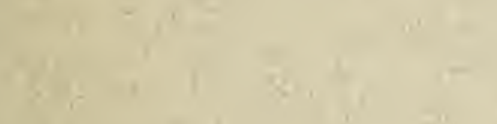

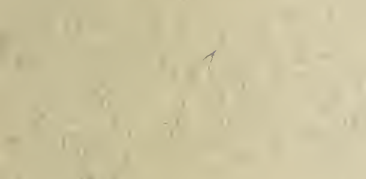


